\title{
Options for the Separation and Immobilization of Technetium
}

\section{September 2016}

RJ Serne

JV Crum

BJ Riley

TG Levitskaia 


\title{
DISCLAIMER
}

This report was prepared as an account of work sponsored by an agency of the United States Government. Neither the United States Government nor any agency thereof, nor Battelle Memorial Institute, nor any of their employees, makes any warranty, express or implied, or assumes any legal liability or responsibility for the accuracy, completeness, or usefulness of any information, apparatus, product, or process disclosed, or represents that its use would not infringe privately owned rights. Reference herein to any specific commercial product, process, or service by trade name, trademark, manufacturer, or otherwise does not necessarily constitute or imply its endorsement, recommendation, or favoring by the United States Government or any agency thereof, or Battelle Memorial Institute. The views and opinions of authors expressed herein do not necessarily state or reflect those of the United States Govermment or any agency thereof.

\author{
PACIFIC NORTHWEST NATIONAL LABORATORY \\ operated by \\ BATTELLE \\ for the \\ UNITED STATES DEPARTMENT OF ENERGY \\ under Contract DE-AC05-76RL01830
}

Printed in the United States of America

Available to DOE and DOE contractors from the

Omce of Scientific and Technical Information.

P.O. Box 62, Oak Ridge, TN 37831-0062:

ph: (865) 576-8.401

fax: (865) 576-5728

email: reportsa adonis,osti.gov

Avallable to the public from the National Technical Information Service

5301 Shawnee Rd., Alexandria, VA 22312

ph: $(800)$ \$53-NTIS (6847)

email: ordencantis gov <http://www.ntis.gov/about/form.aspx>

Online ordering: http:/www.ntis.gov 


\title{
Options for the Separation and Immobilization of Technetium
}

\author{
RJ Serne \\ JV Crum \\ BJ Riley \\ TG Levitskaia
}

September 2016

Prepared for

the U.S. Department of Energy

under Contract DE-AC05-76RL01830

Pacific Northwest National Laboratory

Richland, Washington 99352 


\section{Summary}

Among radioactive constituents present in the Hanford tank waste, technetium-99 (Tc) presents a unique challenge in that it is significantly radiotoxic, exists predominantly in the liquid low-activity waste (LAW), and has proven difficult to effectively stabilize in a waste form for ultimate disposal (see Figure S-1). Within the Hanford Tank Waste Treatment and Immobilization Plant, the LAW fraction will be converted to a glass waste form in the LAW vitrification facility but a significant fraction of Tc volatilizes at the high glass-melting temperatures and is captured in the off-gas treatment system. This necessitates recycle of the off-gas condensate solution to the LAW glass melter feed. The recycle process is effective in increasing the loading of Tc in the immobilized LAW (ILAW), but it also

disproportionately increases the sulfur and halides in the LAW melter feed, which have limited solubility in the LAW glass and thus significantly reduce the amount of LAW (glass waste loading) that can be vitrified and still maintain good waste form properties. This increases both the amount of LAW glass and either the duration of the LAW vitrification mission or requires the need for supplemental LAW treatment capacity.

\section{Baseline Tank Waste Treatment Flowsheet}

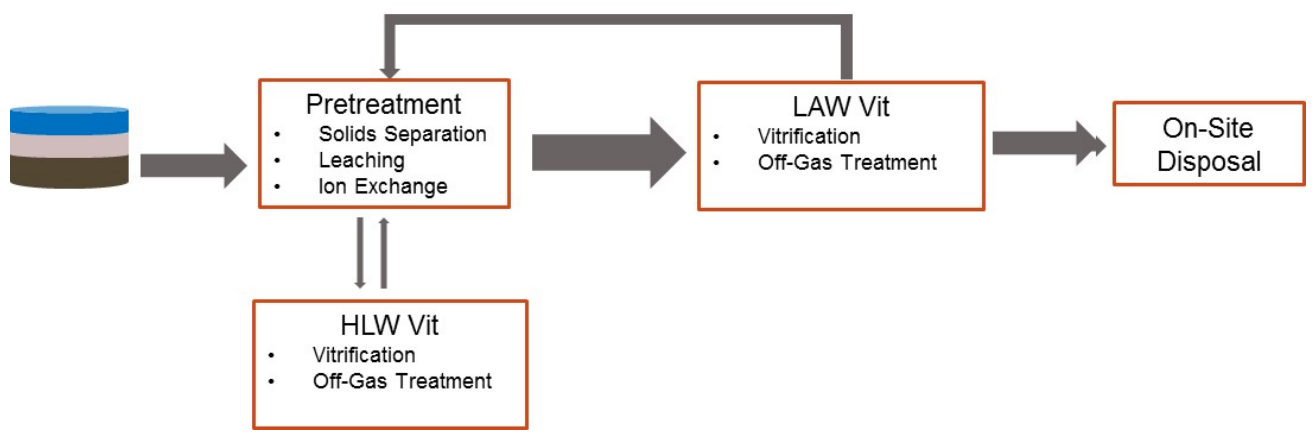

Figure S-1. Tank waste treatment flowsheet: baseline case.

Several options are being considered to address this issue. Two approaches attempt to minimize the off-gas recycle by removing Tc at one of several possible points within the tank waste processing flowsheet as depicted in Figure S-2 for when full WTP operations are ongoing and in Figure S-3 when only the DFLAW operations are active. The separated Tc from these two approaches must then be dispositioned in a manner such that the Tc can be safely disposed. Alternative waste forms that do not have the Tc volatility issues associated with the vitrification process are being sought for immobilization of Tc for subsequent storage and disposal. In 2014, a literature survey was conducted to review the waste forms that have been or are being developed for immobilization of Tc and these are summarized in the report Technetium Immobilization Forms Literature Survey (PNNL-23329) (Westsik et al. 2014). The purpose of our report is to assess the compatibility of removing Tc at locations shown in Figure S-2 when WTP is in full operations and Figure S-3 during DFLAW operations with the candidate Tc-specific waste forms (designated by the "Tc immobilization" boxes in the two figures). 


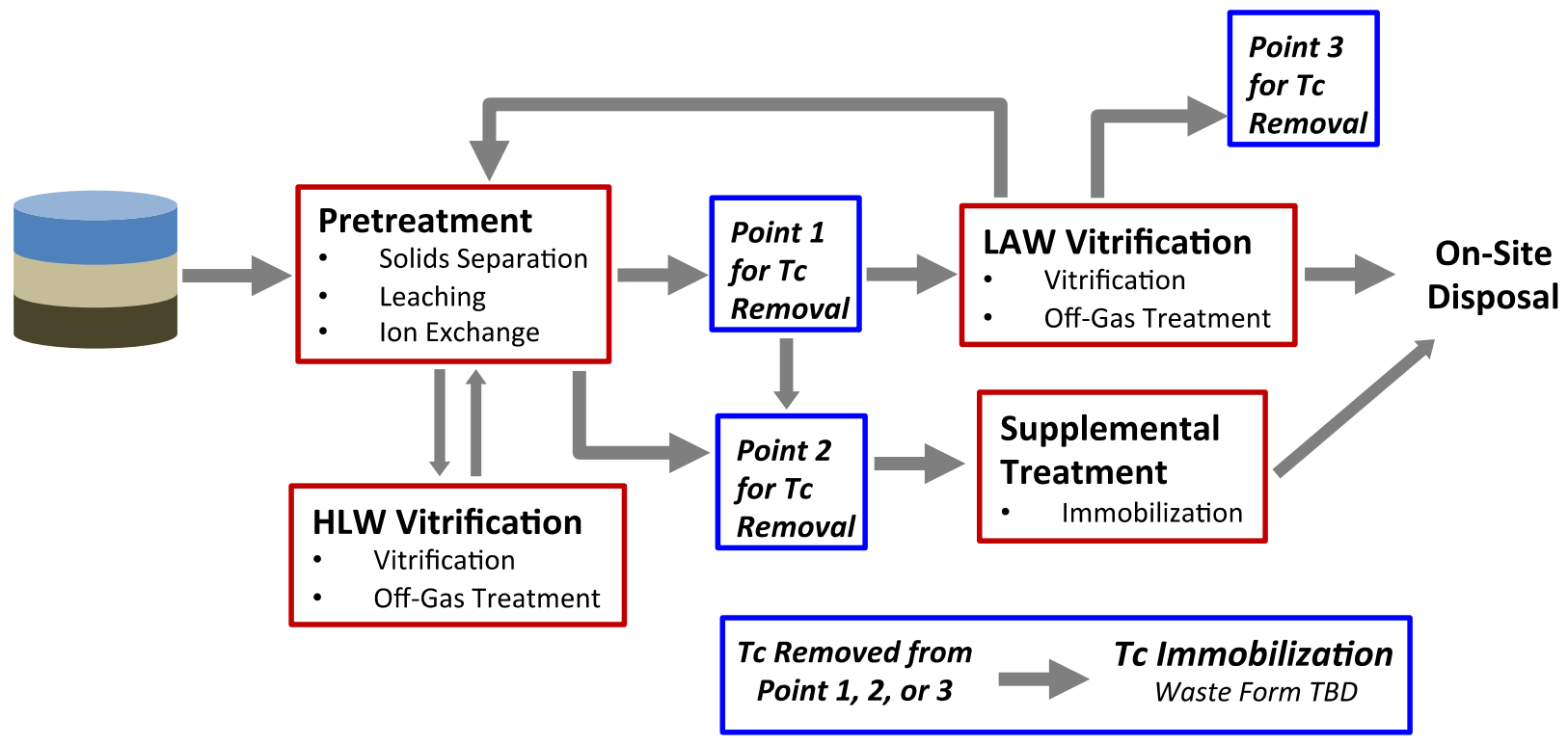

Figure S-2. Technetium Flowsheet: Identification of Tc removal points.

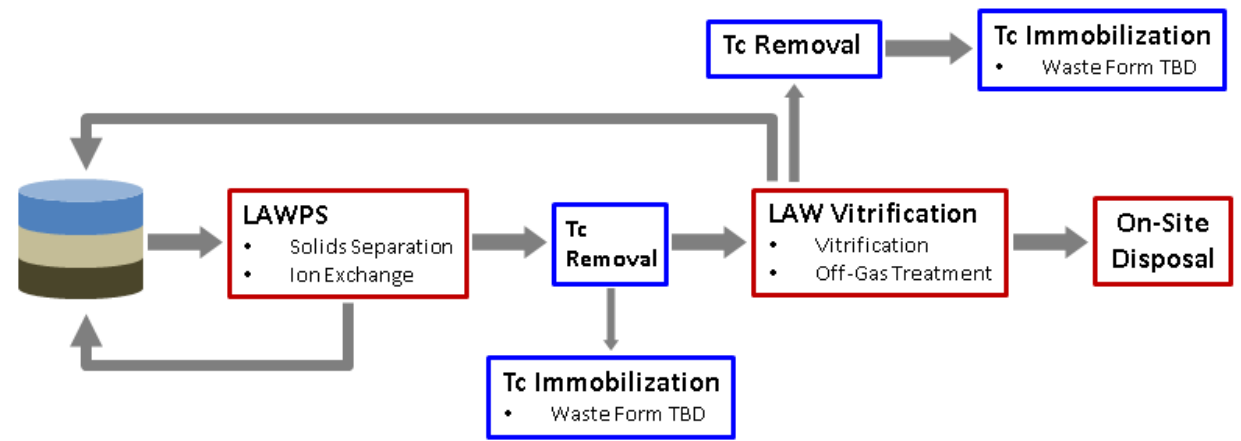

Figure S-3. Technetium Flowsheet: Direct Feed Phase Portion of Overall WTP Mission

The first objective of this report is to provide insights into the compositions and volumes of the Tc bearing waste streams including the ion exchange eluate from processing LAW and the off-gas condensate from the melter. The first step to be assessed will be the processing of ion exchange eluate. Elutable SuperLig 639 resin has been tested extensively for separation of Tc from LAW and is currently the most mature technology for removal of Tc from LAW (McCabe at al. 2012). In this survey, it is assumed that the chemical form of Tc in both the SuperLig 639 eluate and the WTP off-gas condensates and flush waters is $\mathrm{TcO}_{4}^{-}$. Assuming that between 22,000 and 30,000 liters of SuperLig 639 resin recycled 50 times can treat the entire 550 million liters of Hanford tank waste that will be retrieved by the 
end of the WTP mission ${ }^{1}$ and 17 bed volumes (the volume needed in small-scale tests see Burgeson et al. 2004a,b) are needed to elute Tc from the loaded SuperLig 639 resin, the total volume of Tc eluate is estimated between 18.7 and 25.5 million liters. Therefore further concentration and purification of this Tc eluate may be required before the Tc is stabilized in a Tc-specific waste form.

During the DFLAW phase of the WTP mission, two liquid waste streams that capture volatile constituents from LAW melting operations, including Tc, are generated. The off-gas waste stream captured in the Effluent Management Facility (EMF) facility during DFLAW contains $9040 \mathrm{Ci}$ of Tc with the bulk $\sim 7690 \mathrm{Ci}$ of Tc destined for recycling back to the LAW melters and $1350 \mathrm{Ci}$ sent back to DSTs. The waste stream sent back to DSTs is concentrated in dissolved salts. The predicted Na concentration is $4.91 \mathrm{M}$, similar to concentrations currently found in the DSTs. The larger portion of EMF concentrated off-gas liquid waste, which is sent back to the LAW melters, is only concentrated up to a Na concentration of $1.92 \mathrm{M}$. In either case should the EMF concentrated off-gas liquid wastes have Tc removed prior to recycling to the DSTs or to the LAW melters, the relatively high ionic strength would need to be considered. For example direct removal of Tc by traditional anion exchange resins might be challenging given the high ionic strength; however use of SuperLig 639 should be realistic for the concentrated portion currently planned to recycle back to the DSTs.

The HLW WTP facility returns 66.5 million liters of off-gas captured liquid waste to the WTP PT facility over WTP mission Phases 3 and $4^{2}$ but the Tc content in this waste stream is very low ( 2.75 Ci). The LAW melter facility returns $\sim 440$ million liters of off-gas captured liquid waste to the WTP PT facility over Phases 3 and 4 and the projected Tc content is substantial $(\sim 9270 \mathrm{Ci})$. The chemical composition of the LAW off-gas liquid waste stream is dominated by fluoride, chloride and sodium with a total ionic strength of about $0.08 \mathrm{M}$. It would make sense to separate Tc from this off-gas liquid waste stream within the WTP PT facility perhaps using standard ion exchange resins (discussed in Section 5) or some reducing-sorbent process such as using Sn(II)-apatite or Fe(II)-ferric hydrous oxides, however $\mathrm{Cr}$ (VII) concentration in the off-gas liquid waste streams is about 54 times higher than Tc and thus will compete for reductants. Taylor-Pashow et al. (2014a) used $\mathrm{Sn}(\mathrm{II}) \mathrm{Cl}_{2}$ coupled with hydroxyapatite sorbent in a reductive-sorbent precipitation process to remove Tc from an off-gas liquid waste simulant. They found this process was very effective at neutral pH exhibiting Tc Decontamination Factor (DF) $>577$. The process was less effective when the off-gas simulant was adjusted to an alkaline $\mathrm{pH}=12$; where the DF for Tc was reduced to 3.4-3.6. It was also observed that the chromium co-precipitates with the Tc during the $\mathrm{SnCl}_{2}$ reduction.

The second objective of this report is to assess the compatibility of the available waste forms with the anticipated waste streams outlined above. Two major categories of Tc-specific waste forms are considered in this report including mineral and metal waste forms. It appeared that none of the surveyed Tc-specific waste forms can be fabricated using the SuperLig 639 eluate and the off-gas condensates as Tc source streams; goethite being a potential exception, but further studies are required to verify it. Since the primary adsorbents and precipitating agents under investigation are inorganic, they should be compatible with the widest range of disposal options. The long-term stability of organic adsorbents or

\footnotetext{
${ }^{1}$ This volume estimate is found in the detailed "One System" excel spreadsheet that is "embedded” in Arm et al. (2015). We used the detailed "One System" excel spreadsheet throughout this report for volume, waste composition, and Tc inventories.

${ }^{2}$ The WTP Mission phases are defined in Section 3.0 of our report.
} 
precipitation agents is a concern and thus such organic materials are commonly avoided. A number of organic ion exchange media (e.g., Reillex HPQ or Purolite A530E) could also be evaluated. Disposal of the adsorbent/precipitate stream from the Tc removal process is currently undefined but the metal alloy and sodalite processes discussed in Sections 5 and 6 of this review are attractive possibilities. Three potentially feasible approaches for the purification and pre-concentration of $\mathrm{TcO}_{4}{ }^{-}$to generate the waste stream compatible with a Tc-specific waste form are considered in this report; including ion exchange, reductive precipitation using $\mathrm{Sn}(\mathrm{II})$-based materials, and reductive column separation using $\mathrm{Fe}^{0}$. A Tc metal alloy waste form is uniquely compatible with the reductive Sn(II) separation process, which is currently considered for the Tc separation from the off-gas condensate (see Section 4 of this report). The reductive $\mathrm{Fe}^{0}$ column separation method is also an attractive separation technology compatible with the Tc metal alloy waste form but further development of this technology is needed.

Overall it is concluded that a metal alloy waste form is the most promising and mature Tc-specific waste form and offers several benefits. One obvious advantage of the disposition of Tc in the metal alloy waste form is the significant reduction of the generated waste form volume, which leads to a reduction of the required storage facility footprint. This advantage is explained by the fact that the total Tc currently stored in Hanford's tanks is approximately 26,500 Ci (Serne et al., 2014) or $1560 \mathrm{~kg}$. This total Tc inventory can be stabilized in the estimated metal alloy waste form volume of just 1 to $4 \mathrm{~m}^{3}$, depending on the Tc loading. Other benefits of the Tc metal alloy waste form include: easy fabrication requiring few operations, economical and readily available materials (316SS), and resistance to corrosion.

Among mineral waste forms, glass-bonded sodalite and possibly goethite should also be considered for the immobilization of Tc; however, further testing is needed before these technologies are deployed. 


\section{Acknowledgments}

Pacific Northwest National Laboratory is operated by the U.S. Department of Energy under Contract Number DE-AC05-76RL01830. This work was completed as part of the Technetium Management Hanford Site project. Support for this project came from the U.S. Department of Energy's Office of Environmental Management.

We would like to thank Dan McCabe, Savannah River National Laboratory, for providing information and numerous SRNL technical reports on preparing simulants for off-gas condensates and wet electrostatic precipitator flush waters and incorporation of Tc in minerals formed during fluidized bed steam reforming activities on various waste simulants.

We would also like to thank Gregg Lumetta, Brian Rapko, and John Vienna, Pacific Northwest National Laboratory staff for their thorough technical reviews. 



\section{Acronyms and Abbreviations}

\begin{tabular}{|c|c|}
\hline BT & Breakthrough \\
\hline $\mathrm{BV}$ & bed volumes \\
\hline DF & decontamination factor \\
\hline DFLAW & direct-feed LAW \\
\hline DST & double-shell tank \\
\hline$\varepsilon$-metal & $\begin{array}{l}\text { a metal can contain all or a mixture of Mo, Tc, Rh, Rh, and Pd in hexagonal close packed } \\
\text { structure }\end{array}$ \\
\hline EMF & Effluent Management Facility \\
\hline ETF & Effluent Treatment Facility \\
\hline HIS & $\begin{array}{l}\text { Interim handling facility (used to store IHLW before shipment to Federal HLW disposal } \\
\text { facility) }\end{array}$ \\
\hline HLW & high-level waste \\
\hline HTWOS & $\begin{array}{l}\text { Hanford Tank Waste Operations Simulator (computer code for estimating waste stream } \\
\text { compositions and volumes) }\end{array}$ \\
\hline IDF & Integrated Disposal Facility \\
\hline IHLW & immobilized high-level waste (glass) \\
\hline ILAW & immobilized low-activity waste (current baseline is glass) \\
\hline IMUST & inactive miscellaneous underground storage tanks \\
\hline $\mathrm{K}_{\mathrm{d}}$ & $\begin{array}{l}\text { distribution coefficient (measure of SuperLig selectivity for pertechnetate ion units meq/g } \\
\text { resin) }\end{array}$ \\
\hline LAW & low-activity waste \\
\hline LAWPS & Low-Activity Waste Pretreatment System \\
\hline LERF & Liquid Effluent Retention Facility \\
\hline LLW & low-level waste \\
\hline MUST & miscellaneous underground storage tanks \\
\hline PA & Performance assessment \\
\hline PT & Pretreatment \\
\hline PPT & Primary Treatment Train (existing unit operations in ETF) \\
\hline PUREX & Plutonium Uranium Reduction Extraction \\
\hline SBS & submerged bed scrubber (part of melter off-gas treatment facilities) \\
\hline SLAW & Supplemental low activity waste \\
\hline SRF & spherical resorcinol formaldehyde \\
\hline SS & stainless steel \\
\hline
\end{tabular}


STT Secondary Treatment Train (proposed new ETF suite of unit operations to remove radionuclides)

STU Solid treatment unit-new proposed ETF facility

SWRT Secondary Waste Receiver Tanks

T Plant Hanford facility in 200-W Area currently being used to process and store solid wastes

TRF $\quad$ Tc removal facility - new proposed facility by Robbins and May (2013)

TWCS Tank Waste Characterization and Staging (facility)

WESP wet electrostatic precipitator (part of melter off-gas treatment facilities)

WTP Hanford Tank Waste Treatment and Immobilization Plant 


\section{Contents}

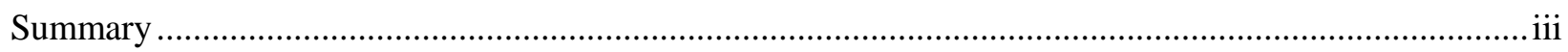

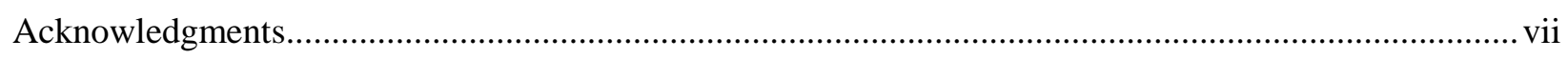

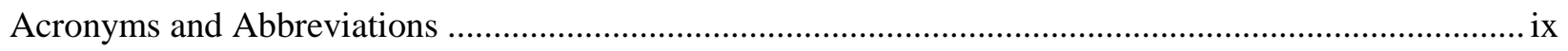

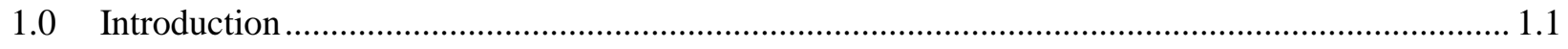

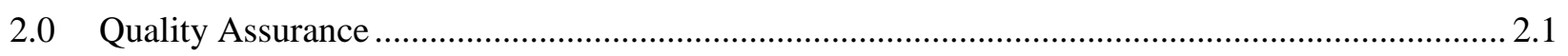

3.0 Composition and Volume of the Tank Waste Sent to Various “Treatment/Handling”

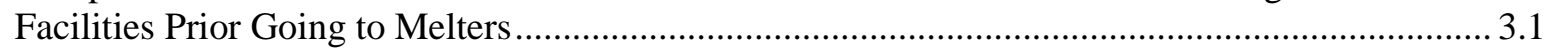

4.0 Composition and Volume of SuperLig 639 Eluate .................................................................... 4.1

5.0 Compositions and Volumes of Off-gas Condensate/Flush Waters ............................................... 5.1

5.1 SRNL Studies on Off-gas Simulants for Fully Operational WTP..................................... 5.21

5.2 SRNL Studies on Off-gas Simulants for Direct Feed LAW .............................................. 5.24

5.3 Comparison of Off-gas Simulants and Secondary Liquid Wastes Transferred to

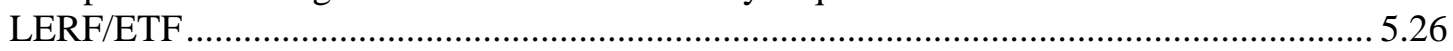

5.4 Proposed Location of Tc Removal Facility from Off-gas Condensates and Flush

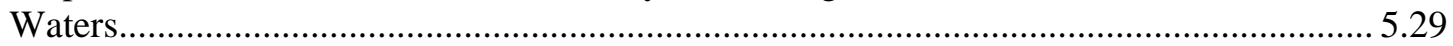

6.0 Review of Options for Purification/Pre-concentration of Tc from the SuperLig 639 Eluate

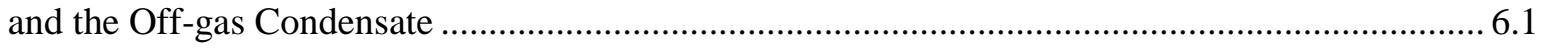

6.1 Option 1: Separation of Tc by Ion Exchange .................................................................... 6.1

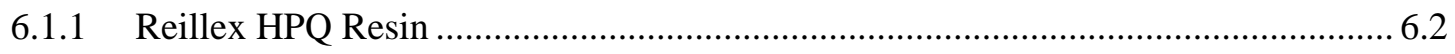

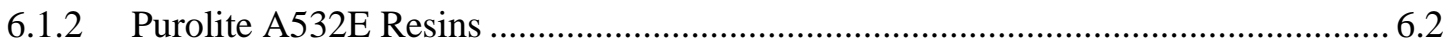

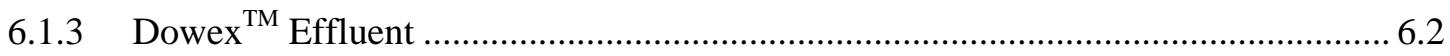

6.2 Option 2: Separation of Tc By Reductive Precipitation .................................................... 6.3

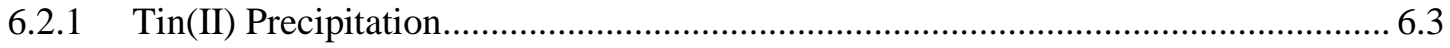

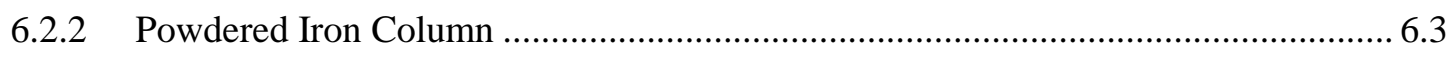

7.0 Immobilization of Purified Pre-concentrated Tc in Specific Waste Forms .................................. 7.1

7.1 Mineral Waste Form Options ............................................................................................ 7.1

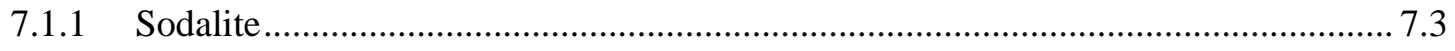

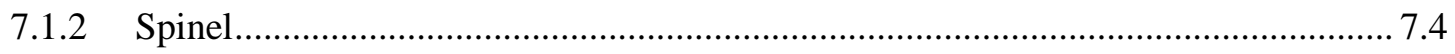

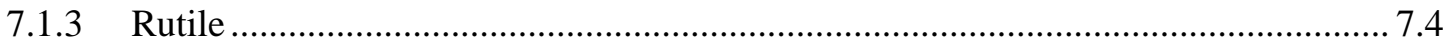

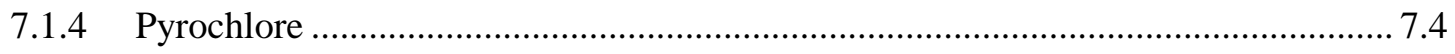

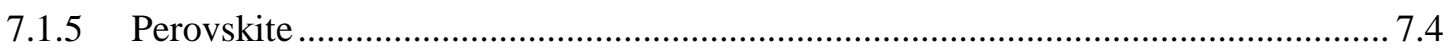

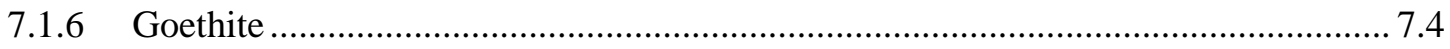

7.1.7 Compatibility of Mineral Waste Forms with Tc Streams ....................................... 7.5

7.2 Metal Alloy Waste Forms ......................................................................................... 7.6

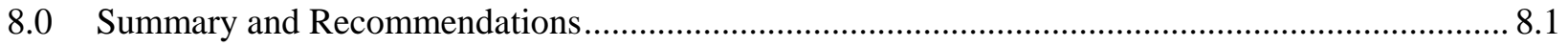

8.1 Recommended Tc-Specific Waste Forms ….............................................................. 8.2

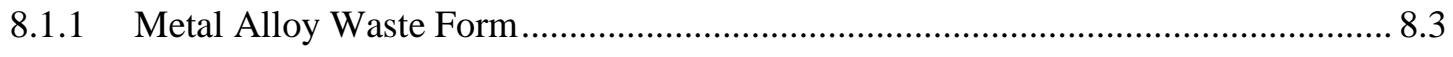




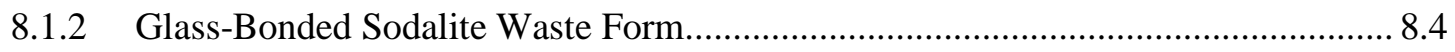

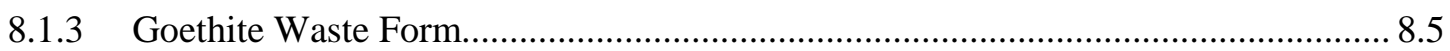

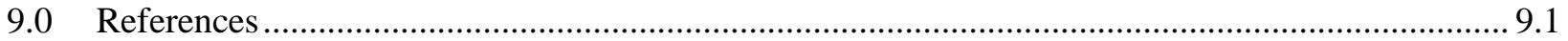

\section{Table of Figures}

1-1. Tc Activities and Potential Removal Points in Simplified WTP Flow Chart, after Thien et al. (2015); see Acronyms and Abbreviations for definitions of the terms found in this figure....1.2

1-2. Assumed Simplified Flowsheet Diagram ..............................................................................

3-1. Overall Hanford Tank Waste Processing Flow Scheme (from Arm et al. 2014) ...................3.3

3-2 Plot of Pertechnetate Kd Value as a Function of Solution Na Concentration (M) with 0.018

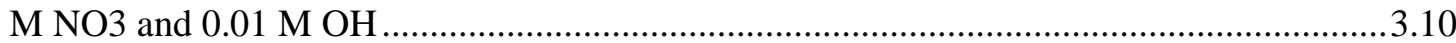

5-1. Schematic for Radionuclide Removal From Off-gas Secondary Waste from McCabe et al.

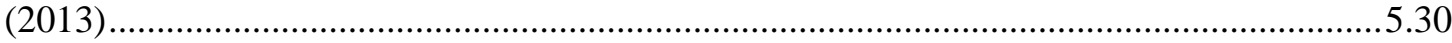

\section{Table of Tables}

1-1. Summary of Tc-Specific Waste Form Options for Separated Tc (Westsik et al. 2014).........1.4

3-1. Locations Where Tc Could be Removed From Tank Waste Prior to Its Being Treated .........3.4

3-2. Volumes, Tc Concentrations and Inventory, and Chemical Concentrations of Tank Waste

Sent to Processing Facilities that Prepare Melter Feed.................................................................

3-3. Tank Waste Na Composition (in M) as a Function of Phase (Time) and Pre-Treatment

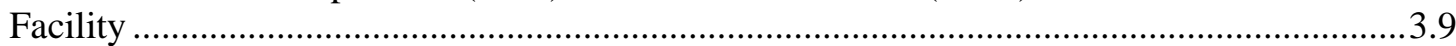

3-4 SuperLig 639 Pertechnetate Sorption $\mathrm{K}_{\mathrm{d}}(\mathrm{mL} / \mathrm{g})$ as a Function of Na Concentration (M).......3.9

3-5. Overall Volume and Tc Inventory (Ci) Transferred From DSTs to PT Facilities.................3.11

3-6. Interfaces Between Treated Tank Waste and Melter Facilities ............................................12

3-7. Volumes, Tc Concentrations and Inventory, and Chemical Concentrations of Treated Tank Waste Sent to Melters

3-8. Treated Tank Waste Na Composition (in M) as a Function of Phase (Time) .......................3.19

3-9. Overall Volume and Tc Inventory (Ci) Transferred From "Pre-treatment" to Melters.........3.19

3-10. Overall Volume and Tc Inventory (Ci) Mass Balance for LAWPS ....................................3.20

4-1. Main Components of the SuperLig 639 Eluate Reported for Processing the Actual Tank

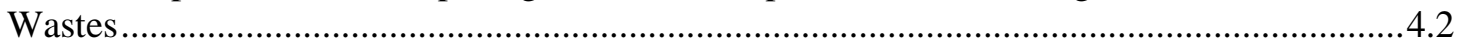

5-1. Interfaces where Liquid Wastes are Sent During DFLAW Operations..................................5.2

5-2. Volumes, Tc Concentrations and Inventory, and Chemical Concentrations of Off-gas Secondary Liquid Waste Concentrated in EMF Before Being Recycled to LAW Melter or Returned to DSTs During DFLAW ...................................................................................... 5.2

5-3. Interfaces where Liquid Wastes Enter and Exit the Pre-Treatment (PT) During Full WTP Operations 
5-4. Volumes, Tc Concentrations, Inventory, and Chemical Concentrations of Waste Entering and Leaving the PT Facility During Full WTP Operations (Phases 3 and 4)

5-5. Mass Balance of Waste Volumes and ${ }^{99}$ Tc Entering and Exiting the PT Facility.....

5-6. Measured Concentrations of Constituents Present in Off-gas Simulant Used in Testing

5-7. Glass Forming Solids Added to Off-gas Simulant (later filtered out) from Plot of Pertechnetate Kd Value as a Function of Solution Na Concentration (M) with $0.018 \mathrm{M} \mathrm{NO}_{3}$ and $0.01 \mathrm{M} \mathrm{OH}$

Taylor-Pashow et al. (2014a)

5-8. DFLAW Off-gas Simulant (measured) and HTWOS Predicted Composition

5-9. Comparison of SRNL Off-gas Simulants (Measured) versus HTWOS Predicted Tank Waste Disposition Integrated Flowsheet Off-gas Waste Streams

5-10. Estimated Time In Yrs. of Operation for WTP Mission Phases Based on Robbins and May (2013) Estimate of the Annual Production of Off-gas Secondary Waste.

6-1. Summary of Tc-capture Options (Duncan et al. 2011). Data for specific types of a sorbent are listed in parenthesis if applicable.

7-1. Summary of Demonstrated Tc-Loadings in Various Minerals. 


\subsection{Introduction}

Technetium-99 (Tc) generated from the fission of ${ }^{235} \mathrm{U}$ and ${ }^{239} \mathrm{Pu}$ in high yields, is one of the most difficult contaminants to be addressed at the U.S. Department of Energy (DOE) Hanford Site. The vast majority of technetium is present in tank wastes. At Hanford, the inventory of Tc in the waste tanks is estimated at 26,500 $\mathrm{Ci}$, and about $1000 \mathrm{Ci}$ in the sediments and soils from leaks and direct discharge (Serne et al. 2014). Among radioactive constituents present in the tank waste, Tc presents a unique challenge in that it is radiotoxic $(\beta=292 \mathrm{keV})$, has a long half-life $\left(t_{1 / 2}=2.13 \times 10^{5} \mathrm{y}\right)$, and exists predominantly in the liquid fraction of the alkaline tank waste, generally in the anionic form of pertechnetate $\mathrm{TcO}_{4}{ }^{-}$, which is highly volatile at low-activity waste (LAW) vitrification melter temperatures and mobile in the subsurface environment (Deutsch et al. 2011). This makes immobilization of Tc into high-durability waste forms a critical technical challenge for nuclear waste management. For waste immobilization and disposal options, the solubility and leaching behavior of technetium are relevant concerns in the performance of various waste forms.

The relatively low concentrations and complex behavior of Tc under storage, treatment, and immobilization conditions significantly affects its management options. A significant uncertainty is associated with the Tc incorporation into various waste forms. In the Hanford Tank Waste Treatment and Immobilization Plant (WTP), waste is split into high-level waste (HLW) and low-activity waste (LAW) fractions, which are melted into HLW and LAW glasses at $1150^{\circ} \mathrm{C}$ (most of the Tc is in the LAW). At these temperatures, a variety of Tc species become volatile, inhibiting Tc's incorporation into the product glass (Darab and Smith 1996; Kim et al. 2006; Pegg 2015; Matlack et al. 2012). The Tc retention in glass measured experimentally over a broad range of waste compositions varied between about 18\% and 63\% (Matlack et al. 2012). The Tc(VII) species such as pertechnetate are especially vulnerable to volatilization. Some additives, such as $\mathrm{Fe}(\mathrm{II})$ oxalate, $\mathrm{ZrO}_{2}$, and sugar, show promise to enhance Tc retention by altering the overall redox or Tc chemistry in the melt process. The Tc retention in glass under reducing conditions can reach $>90 \%$, but average Tc retention in oxic glass forming conditions is assumed close to 35\% (Pegg 2015).

Currently during full WTP operations (when Pre-Treatment facility [PT] is available), volatilized Tc is planned to be captured in off-gas treatment systems. in the off-gas treatment system generates Tc-laden scrubber and water flush solutions, which are then ultimately recycled back to the glass melter after being concentrated by an evaporator. This recycling of off-gas captured fluids also adds sulfate and halides back into the glass melt, which limits the waste-loading of the LAW glass (McCabe et al. 2013; Nash et al. 2014; Taylor-Pashow et al. 2014a,b, 2015). One option to avoid this issue would to be separating Tc from the sulfur and halides in the off-gas waste stream and recycling the Tc itself to the LAW melters. However, this type of manipulation may not always be practical or possible at WTP. In certain situations, separating and incorporating Tc into low-temperature waste forms may be more appropriate; however, the Tc retention mechanisms in low-temperature waste forms need to be understood, and the extent and rate of Tc release from these low-temperature waste forms need to be assessed. 
One option being considered is to remove the Tc at one of several possible points within the tank waste processing flowsheet (denoted by numbered red circles in Figure 1-1) ${ }^{3}$ so that the LAW melter offgas condensates do not need to be recycled. Technetium can be either removed from LAW prior to subjecting it to vitrification (see Points \#1, \#2, and \#3 in Figure 1-1) or from the off-gas liquid waste streams (see Point \#4). The separation of Tc from LAW has been previously considered within the WTP flowsheet (McCabe et al. 2012), and the removal of the most abundant in LAW anionic Tc species, which is present in the chemical form of pertechnetate $\mathrm{TcO}_{4}{ }^{-}$, is successfully achieved by the elutable SuperLig ${ }^{\circledR}$ 639 resin, ${ }^{4}$ the technology most developed to-date for the separation of pertechnetate from the caustic high-in-sodium solutions typifying LAW. Technetium can be easily eluted from the loaded SuperLig 639 resin by warm water (Burgeson et al. 2004a,b). The technology for the removal of Tc from the off-gas stream is currently being developed (McCabe et al. 2013; Taylor-Pashow et al. 2014a,b, 2015).

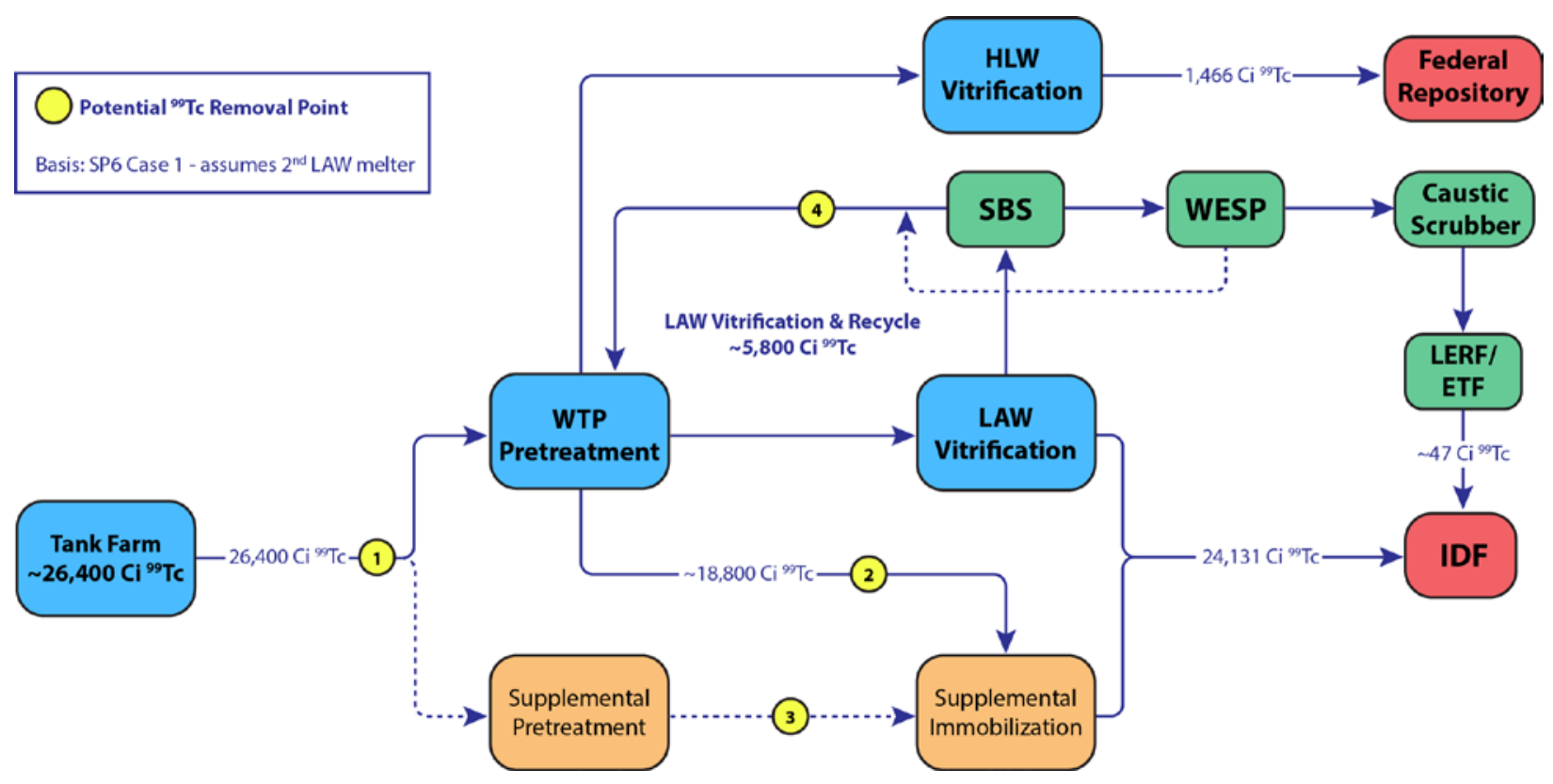

Figure 1-1. Tc Activities and Potential Removal Points in Simplified WTP Flow Chart, after Thien et al. (2015); see Acronyms and Abbreviations for definitions of the terms found in this figure.

Impacts of Tc removal from aqueous waste streams on WTP flowsheet have been previously reviewed (Brown et al. 2014). The major benefits include elimination of a key risk contributor for the Integrated Disposal Facility (IDF) performance assessment (PA) for supplemental waste forms and potential reduction of overall treatment and waste disposal costs due to minimization of the off-gas recycle. If Tc is removed from LAW prior to its vitrification using an elutable ion exchange resin (SuperLig 639) or from off-gas concentrate, a Tc-concentrated stream is generated that will require

\footnotetext{
${ }^{3}$ Note that Figure 1-1 is a simplified version of the WTP flow sheet and has been superseded. The current flow sheet with volumes of liquid waste, Tc inventory, and waste composition as a function of time are discussed in Section 2.

${ }^{4}$ The SuperLig ${ }^{\circledR} 639$ technology is based on ion pair extraction in which the $\mathrm{Na}^{+}$ion is complexed by a macrocyclic ligand and $\mathrm{TcO}_{4}{ }^{-}$is co-transported with it as the counter anion (driven by the relatively low hydration energy for $\left.\mathrm{TcO}_{4}{ }^{-}\right)$.
} 
disposal. One disposal pathway is through HLW vitrification. It will require component concentration through evaporation and slight changes in the flowsheet and facility operations associated with a need for a new path for routing of the concentrated Tc stream to HLW facility and adding it to the HLW stream. Impacts on HLW will need to be evaluated. Alternatively, the Tc concentrate can be immobilized in a Tcspecific waste form and either sent to IDF or sent off-site for disposal (Figure 1-2). However, currently there is insufficient information to support the selection of a preferred method of disposing the Tc concentrate, and additional R\&D is needed.

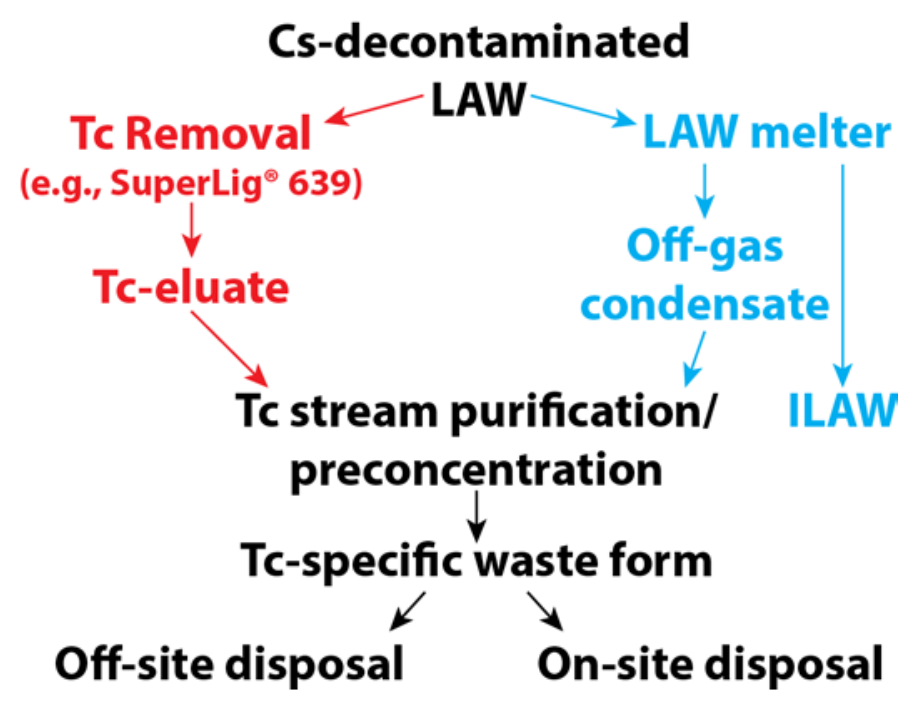

Figure 1-2. Assumed Simplified Flowsheet Diagram

Technetium, separated either from LAW prior to its vitrification using SuperLig 639 resin or removal of Tc from off-gas and scrubber condensates and wet electrostatic precipitator (WESP) flushes by various processes, can then be dispositioned in a waste form specifically designed to immobilize the Tc. Previous work was focused on the identification of candidate Tc immobilization technologies. The report Technetium Immobilization Forms Literature Survey (PNNL-23329) (Westsik et al., 2014) describes Tc-specific waste forms that have been or are being developed for immobilization of Tc. The advantages and disadvantages of these options are briefly summarized in Table 1-1. Based on the results of their Tc waste forms literature survey and understanding of currently funded research, the Technetium Management Program project team identified metal alloys and sodalite as two waste forms for continued development for immobilization of the separated Tc. Sodalite waste form development as described in the literature indicates that other common anions in the eluate from the Tc separation processes could compete with $\mathrm{TcO}_{4}{ }^{-}$for immobilization sites in the sodalite waste form structure. The metal alloys also require purification and reduction of Tc to forms that can be readily incorporated into the alloy.

The current study is focused on conducting a literature review to provide insights into the compositions and volumes of the potential WTP waste streams, including the SuperLig 639 eluate and the off-gas condensate/flush waters generated during LAW vitrification. The information obtained from this review is used to examine the compatibilities of these waste streams with Tc-specific waste forms and operations required for Tc immobilization in the candidate waste forms. 
Table 1-1. Summary of Tc-Specific Waste Form Options for Separated Tc (Westsik et al. 2014)

\begin{tabular}{|c|c|c|}
\hline $\begin{array}{l}\text { Waste } \\
\text { Form }\end{array}$ & Advantages & Disadvantages \\
\hline $\begin{array}{l}\text { E-metal } \\
\text { alloys }\end{array}$ & $\begin{array}{l}\text { - } \quad \text { Low-volume waste form } \\
\text { - } \text { migrural analogs show essentially no } \\
\text { - Work has been done to create and } \\
\text { characterize epsilon metal alloy as a } \\
\text { waste form } \\
\text { - Volatility of Tc at high temperatures } \\
\text { - } \text { not an issue for Tc metal } \\
\text { Relatively mature waste form }\end{array}$ & $\begin{array}{l}\text { - } \text { Requires expensive and precious metal } \\
\text { to form the alloy } \\
\text { - High-temperature melting process } \\
\text { - Requires reduction of Tc to the metal }\end{array}$ \\
\hline $\begin{array}{l}\text { Stainless } \\
\text { steel alloys }\end{array}$ & $\begin{array}{l}\text { - } \quad \text { Low-volume waste form } \\
\text { - } \quad \text { stainlensive characterization of } \\
\text { - } \quad \text { Volatility of Tc at high temperatures } \\
\text { - } \quad \text { Rot an issue for Tc metal } \\
\text { - } \quad \text { Projected lifetimes higher than } \varepsilon^{-} \\
\text {metal }\end{array}$ & $\begin{array}{l}\text { - High-temperature melting process } \\
\text { - } \quad \text { Requires reduction of Tc to the metal } \\
\mathrm{Tc}^{0}\end{array}$ \\
\hline $\begin{array}{l}\text { Fe-Tc } \\
\text { oxides }\end{array}$ & $\begin{array}{l}\text { - Iron oxyhydroxides relatively stable } \\
\text { in subsurface oxic environments } \\
\text { - Forms stable crystal structure with Tc } \\
\text { - Potential to add protective "barrier" } \\
\text { coating to further isolate Tc } \\
\text { - Low-temperature process }\end{array}$ & $\begin{array}{l}\text { - Other anions compete with Tc } \\
\text { - } \text { Relatively immature waste form } \\
\text { - } \\
\text { Product is a granular material that } \\
\text { requires encapsulation to form the } \\
\text { final waste form }\end{array}$ \\
\hline Tc-oxides & - Crystalline waste form & - Immature waste form \\
\hline Silicates & - Crystalline waste form & - Immature waste form \\
\hline Titanates & $\begin{array}{l}\text { - Form crystalline ceramic structure } \\
\text { with } \mathrm{Tc}^{4+}\end{array}$ & $\begin{array}{l}\text { - Require high-temperature sintering in } \\
\text { an inert atmosphere } \\
\text { - No information available regarding } \\
\text { effectiveness of the Tc titanate } \\
\text { minerals in controlling the release of } \\
\text { the Tc in leaching } \\
\text { - Immature waste form }\end{array}$ \\
\hline
\end{tabular}


Table 1-1. (continued)

\begin{tabular}{|c|c|c|}
\hline $\begin{array}{l}\text { Waste } \\
\text { Form }\end{array}$ & Advantages & Disadvantages \\
\hline Sulfides & $\begin{array}{l}\text { - Tc sulfide species have very low } \\
\text { solubility } \\
\text { - } \\
\text { - } \\
\text { Reduce Tc oxides to } \mathrm{TcS}_{2} \\
\text { Tc in grout waste forms with blast } \\
\text { furnace slag }\end{array}$ & $\begin{array}{l}\text { - Readily oxidize in presence of oxygen } \\
\text { to form soluble species with high } \\
\text { mobility } \\
\text { - Path to forming a waste form for } \\
\text { disposal is undefined } \\
\text { - Immature waste form }\end{array}$ \\
\hline $\begin{array}{l}\text { Phosphate- } \\
\text { apatites }\end{array}$ & $\begin{array}{l}\text { - Sn(II)-treated apatites are being } \\
\text { evaluated as means to enhance } \\
\text { retention of Tc in Cast Stone waste } \\
\text { form }\end{array}$ & $\begin{array}{l}\text { - Relatively immature technology as a } \\
\text { waste form } \\
\text { - Re-oxidation of sequestered Tc is a } \\
\text { concern such that long-term stability } \\
\text { remains to be demonstrated } \\
\text { - } \text { Path to forming a final stable waste } \\
\text { form that contains Tc-laden Sn(II)- } \\
\text { treated apatite for disposal is } \\
\text { undefined }\end{array}$ \\
\hline $\begin{array}{l}\text { Layered } \\
\text { double } \\
\text { hydroxides }\end{array}$ & $\begin{array}{l}\text { - Developed as a separations } \\
\text { technology for medical isotope } \\
\text { industry and for contaminated } \\
\text { wastewater treatment }\end{array}$ & $\begin{array}{l}\text { - Relatively immature technology as a } \\
\text { waste form } \\
\text { - LDH would likely need to be } \\
\text { encapsulated in another waste form } \\
\text { - Other anions in waste will compete } \\
\text { with } \mathrm{TcO}_{4}^{-} \text {and will likely preclude Tc } \\
\text { incorporation into LDH } \\
\text { - Immature waste form }\end{array}$ \\
\hline $\begin{array}{l}\text { Sulfide- } \\
\text { aerogels }\end{array}$ & $\begin{array}{l}\text { - Being developed for environmental } \\
\text { remediation applications }\end{array}$ & $\begin{array}{l}\text { - Testing needed to evaluate efficacy for } \\
\text { caustic tank waste applications } \\
\text { - Path to forming a waste form for } \\
\text { disposal is undefined } \\
\text { - Resistance to oxidation in the disposal } \\
\text { environment is unknown } \\
\text { - Immature waste form }\end{array}$ \\
\hline
\end{tabular}

One obvious advantage of the disposition of Tc in a specific waste form is the significant reduction of the generated waste-form volume leading to the reduction of the required waste-form fabrication and storage facility footprints. This advantage is explained by the fact that total Tc currently stored in Hanford's tanks is approximately $2.65 \times 10^{4} \mathrm{Ci}$ (Serne et al. 2014) or $1,560 \mathrm{~kg}$, a major fraction of which ends up in LAW after separating the tank waste into the two fractions, HLW and LAW. If a Tc specific separation process is found that pre-concentrates Tc that then can be readily loaded into a Tc- specific 
waste form, the total volume of Tc-bearing waste could be small (e.g., $250 \mathrm{~L}$ total; based on reasonable Tc loading of $20 \mathrm{wt} \%$ into metal alloys). See Section 7.2 for more discussion.

In this survey, it is assumed that the chemical form of Tc in both the SuperLig 639 eluate and the WTP off-gas condensates and flush waters is $\mathrm{TcO}_{4}{ }^{-}$. While it has been previously established that the SuperLig 639 resin is capable of separating only $\mathrm{TcO}_{4}{ }^{-}$and therefore it is the only Tc form appearing in the strip solution, the chemical speciation of Tc in the off-gas condensate and equipment flush waters has not been experimentally confirmed. Nevertheless, considering that melter environment is oxidizing and since the volatility of $\mathrm{Tc}(\mathrm{VII})$ is much greater than that of $\mathrm{Tc}(\mathrm{IV})$ during $\mathrm{LAW}$ vitrification, the assumption that $\mathrm{TcO}_{4}{ }^{-}$is the dominant Tc form in the off-gas condensate and flush waters is reasonable.

The rational choice of the preferred processing scheme to purify and pre-concentrate the Tc stream requires the knowledge of the compositions and volumes of the SuperLig 639 eluate and the off-gas condensates/flush waters. There are three potentially feasible approaches for the purification and preconcentration of $\mathrm{TcO}_{4}{ }^{-}$to generate the waste stream compatible with a Tc-specific waste form including the following:

- $\quad$ ion exchange (Brown et al. 2014; McCabe et al. 2012; Duncan et al. 2011; and references therein),

- $\quad$ reductive precipitation, e.g., using $\mathrm{Sn}^{2+}$ either alone or in combination of another sorbent such as hydroxy-apatite (McCabe et al. 2013; Taylor-Pashow et al. 2014a; Duncan et al. 2012), and

- reductive column separation (Ebert et al. 2009; Del Cul and Bostick 1995); it was reported that the efficiency or capacity of $\mathrm{Fe}^{0}$ for $\mathrm{Tc}^{7+}$ removal is higher than Reillex ${ }^{\circledR}$ HPQ performance. 


\subsection{Quality Assurance}

This work was conducted as part of Pacific Northwest National Laboratory (PNNL) Project 54042 under the Technetium Management Program, with funding from the U.S. Department of Energy Office of Environmental Management.

All research and development (R\&D) work at PNNL is performed in accordance with PNNL's laboratory-level Quality Management Program, which is based on a graded application of NQA-1-2000, Quality Assurance Requirements for Nuclear Facility Applications, to R\&D activities. In addition to the PNNL-wide quality assurance (QA) controls, the QA controls of the WRPS Waste Form Testing Program (WWFTP) QA program were also implemented for the work. The WWFTP QA program consists of the WWFTP Quality Assurance Plan (QA-WWFTP-001) and associated QA-NSLW-numbered procedures that provide detailed instructions for implementing NQA-1 requirements for R\&D work. The WWFTP QA program is based on the requirements of NQA-1-2008, Quality Assurance Requirements for Nuclear Facility Applications, and NQA-1a-2009, Addenda to ASME NQA-1-2008 Quality Assurance Requirements for Nuclear Facility Applications, graded on the approach presented in NQA-1-2008, Part IV, Subpart 4.2, "Guidance on Graded Application of Quality Assurance (QA) for Nuclear-Related Research and Development”. Preparation of this report was assigned the technology level "Applied Research" and was conducted in accordance with procedure QA-NSLW-1102, Scientific Investigation for Applied Research. All staff members contributing to the work have technical expertise in the subject matter and received QA training prior to performing quality-affecting work. The "Applied Research"

technology level provides adequate controls to ensure that the activities were performed correctly. Use of both the PNNL-wide and WWFTP QA controls ensured that all client QA expectations were addressed in performing the work. 


\subsection{Composition and Volume of the Tank Waste Sent to Various "Treatment/Handling" Facilities Prior Going to Melters}

The current overall WTP flow sheet includes using several new facilities that will be constructed to allow "direct feed" of tank waste to the LAW and HLW waste melters because the WTP pretreatment facility (PT) will not be available as soon as tank waste will be ready for vitrification. Two new facilities are approved (and currently in conceptual design) to allow for vitrification before PT is available. The two facilities are the Low-Activity Waste Pretreatment System (LAWPS) ${ }^{5}$ and the Effluent Management Facility (EMF) ${ }^{6}$. A third facility, Tank Waste Characterization and Staging Facility (TWCS) ${ }^{7}$ is also under consideration but not approved or in conceptual design to handle tank waste streams ahead of the WTP PT facility.

Figure 3-1 is the current comprehensive flow sheet depicting the fate of tank farm stored waste through the various WTP waste processing facilities to their ultimate disposal. The figure shows existing, approved and designed but not completed, and future proposed facilities. Using the computer code HTWOS, the volumes of most waste streams (both liquid and solid) and the chemical and radionuclide composition of the various wastes have been estimated from the start of the tank waste retrieval through the vitrification/solidification campaigns all the way to the end, when all wastes except residual heels have been removed from the tanks and processed into glass and other solid waste forms. The current estimates of waste volumes and constituent masses/activities are binned into four phases of operation.

Phase 1 is called Near-Term Operations and runs from now until direct-feed LAW (DFLAW) operations begin. During Phase 1 the major activities include retrieving waste from the $\mathrm{C}, \mathrm{A}$, and AX single shell tank farms and concentrating some of the currently double-shell tank (DST) stored waste in the 242-A Evaporator.

\footnotetext{
${ }^{5}$ LAWPS is currently in the conceptual design phase. For the DFLAW flowsheet element, the waste from the DSTs will be treated in the LAWPS. Treatment will consist of filtration with cross-flow membranes and removal of the cesium using elutable ion exchange (IX). The cross-flow filtration system separates entrained solids from the supernate and returns the solids to the DSTs, and the IX removes cesium from the supernate. The treated waste is then fed directly to the WTP LAW Vitrification Facility, bypassing the WTP PT Facility. Secondary liquid waste from the IX elution (cesium product) and filtration flushes will be routed back to the Tank Farms.
}

${ }^{6}$ The EMF is currently in the conceptual design phase. The main function of the EMF will be to concentrate secondary liquid effluent from the LAW off-gas treatment system during DFLAW operations. The overhead condensate stream will be transferred to the LERF/ETF facility. The bottom slurry concentrate stream will be partially recycled back to the LAW feed tank in the LAW Vitrification Facility (melter). Any remaining slurry concentrate not sent directly to the melter will be treated for corrosion control and returned to DSTs.

${ }^{7}$ TWCS is a proposed new facility that would provide improved tank waste slurry mixing, sampling and characterization, conditioning and staging of waste before it is fed to the WTP. Once WTP PT is brought online, the Integrated Flowsheet assumes TWCS will stage and certify waste batches before they are sent to WTP PT for processing. TWCS would also perform other processing functions (e.g., waste particle segregation and size reduction) as required to meet PT waste acceptance criteria. 
Phase 2 is called the DFLAW operations and runs from the startup of DFLAW until WTP PT operations begin. The major activities that occur in Phase 2 include operation of the LAWPS to supply DFLAW to the WTP LAW melters, receipt and handling of DFLAW secondary liquid wastes in DST tanks, sending ILAW to IDF, sending some secondary liquid wastes to both LERF/ETF and DST tanks, continued SST retrievals, and continued use of the 242-A Evaporator operations.

Phase 3 is called WTP Full Operations and runs from the startup of WTP PT operations until the Balance of Mission operations begin. The major activities in Phase 3 include switching from DFLAW to HLW processing utilizing the WTP PT Facility, continued operation of LAW melters, operating the HLW melters, continued sending ILAW to IDF, sending IHLW to the interim handling facility (IHS) and when possible shipment of IHLW to the Federal Geological Nuclear Waste Repository, operation of TWCS to supply slurry to the WTP PT Facility, sending WTP secondary liquid wastes to LERF/ETF for final processing, continued SST retrievals and continued use of 242-A Evaporator to concentrate liquid wastes.

Phase 4 is called Balance of Mission, and runs from the startup of the supplemental low-activity waste immobilization (SLAW) facility through the end of the tank clean-up mission. The Balance of Mission activities are further split into three times, designated as Phase 4-A, Phase 4-B and Phase 4-C to allow more details to be provided. The key activities constituting Phase 4 include continued operation of the LAW and HLW melters, operation of SLAW Immobilization for excess LAW (supplied by both WTP PT and LAWPS as needed), continued sending of ILAW to IDF and IHLW to IHS, continued operation of TWCS to supply slurry to the WTP PT Facility, continued sending secondary liquid wastes to LERF/ETF, continued SST retrievals, continued operation of the 242-A Evaporator, cleanout of PUREX and T-Plant, and perhaps retrieving wastes from miscellaneous underground storage tanks (MUST).

The HTWOS estimates, documented in an Excel file "RPP Reference Integrated Flowsheet Mass Flow Calculations” dated $08 / 03 / 2015^{8}$, for volumes of liquid waste and chemical and Tc concentrations in various waste streams for these four phases of operation are listed in the following tables for key locations where Tc removal might be performed, that is, locations of interest to this review activity. We have combined the data for both the solution phase and suspended solids in the following tables for each waste stream and phase of operation. The overall detailed flow chart in Figure 3-1 contains 85 interfaces (shown as numbered diamonds) between the various facilities. These 85 interfaces are defined in Arm et al. (2014) in their Table 3-1.

\footnotetext{
${ }^{8}$ The chemical composition projections listed in this spreadsheet are limited to key analytes. Key analytes were chosen based on components that limit glass formulation, and oxalate, which was added to the list as an important analyte due to its impact on waste chemical stability, sludge washing and melter reduction/oxidation calculations. The total organic carbon (TOC) reported was assumed to be all acetate because HTWOS reports oxalate separately. The HTWOS code tracks many more chemical constituents and radionuclides but we could not get the complete HTWOS outputs to augment the species reported in the cited Excel spreadsheet and discussed in Arm et al. (2014, 2015).
} 


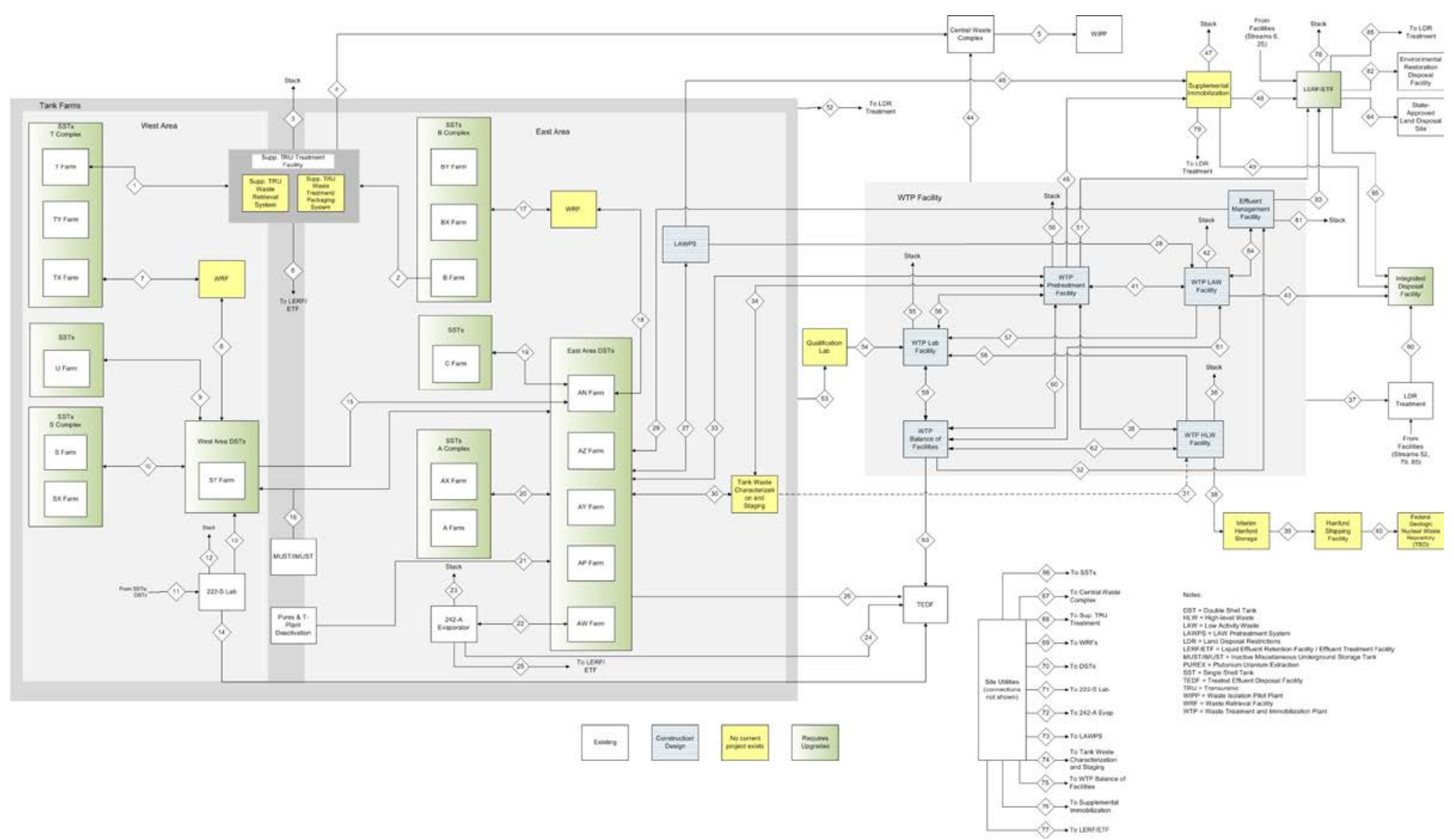

Figure 3-1. Overall Hanford Tank Waste Processing Flow Scheme (from Arm et al. 2014) 
Our interest in this section is constructing a summary of the interfaces that constitute tank waste sent to the various facilities that process the tank waste into liquid waste feed streams that ultimately go to the melters (both LAW and HLW and the currently assumed SLAW melters). We tabulate these estimates by Phase (as defined above) in Table 3-1 (below). The locations (interfaces) that we believe would be of interest for removal of Tc from the tank waste as it enters into "pre-treatment" facilities but before any processing within the "pre-treatment" facilities are shown in our Table 3-1, which is excerpted from Arm et al. (2014) in their Table 3-1. Recall that the locations of interfaces in our Table 3-1 are some of the diamonds in Figure 3-1. We keep the interface numbering system the same as used by Arm et al. (2014). The "a" designation represents waste streams entering a facility, and the "b" designation represents waste leaving a facility. Thus in Table 3-1 the "a" designation represents liquid waste streams entering the various pre-treatment facilities (LAWPS, TWCS, WTP PT). It would also be possible to remove Tc within the various "pre-treatment” facilities after process steps such as solids filtration and/or ${ }^{137} \mathrm{Cs}$ removal or at the end of any "pre-treatment" operation just before sending the wastes to the melters. The interfaces that represent "treated tank" waste going to the LAW-, assumed SLAW-, and HLW-melters are 28, 41a, 84a for LAW melters, 45 and 46 for SLAW melters, and 31 and 35a for HLW melters, respectively. Discussion on volumes of waste, chemical composition and Tc inventories for these interfaces are discussed at the end of this section.

Table 3-1. Locations Where Tc Could be Removed From Tank Waste Prior to Its Being Treated

\begin{tabular}{|c|c|c|c|c|}
\hline Interface & $\begin{array}{c}\text { Interface } \\
\text { Name }\end{array}$ & From & To & Primary Flow \\
\hline $27 a$ & $\begin{array}{l}\text { Waste to } \\
\text { LAWPS }\end{array}$ & $\begin{array}{l}\text { East Area } \\
\text { DSTs }\end{array}$ & LAWPS & Supernate Waste (DFLAW) \\
\hline $30 \mathrm{a}$ & $\begin{array}{l}\text { HLW to } \\
\text { TWCS }\end{array}$ & $\begin{array}{l}\text { East Area } \\
\text { DSTs }\end{array}$ & TWCS & Slurry Waste \\
\hline $33 a$ & $\begin{array}{l}\text { LAW Feed to } \\
\text { WTP PT }\end{array}$ & $\begin{array}{l}\text { East Area } \\
\text { DSTs }\end{array}$ & $\begin{array}{l}\text { WTP Pretreatment } \\
\text { Facility }\end{array}$ & Supernate Waste (LAW) \\
\hline $34 a$ & $\begin{array}{l}\text { HLW Feed to } \\
\text { WTP PT }\end{array}$ & TWCS & $\begin{array}{l}\text { WTP Pretreatment } \\
\text { Facility }\end{array}$ & Slurry Waste \\
\hline
\end{tabular}

Table 3-2 lists the volume weighted masses of key waste stream chemicals in units of $\mathrm{mg} / \mathrm{L}$ and molarity (M) and volume weighted Tc inventory in curies for all 4 operational phases of the WTP mission.9 Because the volume weighted averages do not honor the individual durations of the phases we have also parsed out the Na composition by phases so that one can see what the average Na composition is versus time. This is important because the SuperLig 639 resin (to date the most mature technology for Tc separation from LAW) works best when the sodium (actually total alkali metal) concentration is about

\footnotetext{
${ }^{9}$ Volume weighted averages are calculated by taking the projected composition of each chemical for each Phase of the WTP mission multiplied by the projected volume of waste produced for the given Phase of the WTP mission and then summing the resultant masses for each phase and finally dividing by the total volume (sum of each phase's volumes). If Tc separation was in fact performed it likely would be performed for each Phase of the WTP mission in "real" time. We used volume averaging solely to get an overview of the waste composition for the entire WTP mission for each facility.
} 
Table 3-2. Volumes, Tc Concentrations and Inventory, and Chemical Concentrations of Tank Waste Sent to Processing Facilities that Prepare Melter Feed

\begin{tabular}{|c|c|c|c|c|c|c|c|c|}
\hline Phase: & 1 & 2 & 3 & $4 A$ & 4B & $4 C$ & \multirow{2}{*}{$\begin{array}{c}\text { Vol } \\
\text { Weighted } \\
\text { Ave } \\
\end{array}$} & \multirow{2}{*}{$\begin{array}{c}\text { Vol } \\
\text { Weighted } \\
\text { Ave } \\
\end{array}$} \\
\hline Interface $^{(*)}$ & $27 a$ & $27 a$ & $27 a$ & $27 a$ & $27 a$ & $27 a$ & & \\
\hline $\begin{array}{l}\text { Chemical } \\
\text { Comp. (mg/L) }\end{array}$ & None $^{(a)}$ & & none & & & none & $\mathrm{mg} / \mathrm{L}$ & M \\
\hline Aluminum & & $1.52 \mathrm{E}+03$ & & $4.12 \mathrm{E}+03$ & $2.25 \mathrm{E}+03$ & & $2.37 \mathrm{E}+03$ & $8.79 \mathrm{E}-02$ \\
\hline Bismuth & & $\mathrm{NR}^{(\mathrm{b})}$ & & $6.31 \mathrm{E}+01$ & $9.05 \mathrm{E}+01$ & & $2.26 \mathrm{E}+01$ & $1.08 \mathrm{E}-04$ \\
\hline Chlorine & & NR & & $2.10 \mathrm{E}+03$ & $1.80 \mathrm{E}+03$ & & $7.20 \mathrm{E}+02$ & 2.03E-02 \\
\hline Chromium & & $1.84 \mathrm{E}+01$ & & $6.29 \mathrm{E}+02$ & $6.85 E+02$ & & $2.31 \mathrm{E}+02$ & 4.45E-03 \\
\hline Fluorine & & $2.30 \mathrm{E}+00$ & & $5.17 \mathrm{E}+02$ & $2.48 \mathrm{E}+03$ & & $2.31 \mathrm{E}+02$ & $1.22 \mathrm{E}-02$ \\
\hline Iron & & NR & & $6.37 \mathrm{E}+01$ & $6.19 \mathrm{E}+01$ & & $2.20 \mathrm{E}+01$ & $3.94 \mathrm{E}-04$ \\
\hline Nickel & & $7.48 \mathrm{E}-01$ & & $1.41 \mathrm{E}+00$ & 1.33E-01 & & $9.45 \mathrm{E}-01$ & $1.61 \mathrm{E}-05$ \\
\hline Nitrate & & $4.35 \mathrm{E}+03$ & & $4.51 \mathrm{E}+04$ & $2.87 E+04$ & & $1.80 \mathrm{E}+04$ & $2.91 \mathrm{E}-01$ \\
\hline Nitrite & & $1.55 \mathrm{E}+04$ & & $1.21 \mathrm{E}+05$ & $1.10 \mathrm{E}+05$ & & $5.18 \mathrm{E}+04$ & $1.13 \mathrm{E}+00$ \\
\hline Potassium & & NR & & $3.04 \mathrm{E}+03$ & $2.10 \mathrm{E}+03$ & & $1.03 E+03$ & 2.63E-02 \\
\hline Phosphate & & $2.30 \mathrm{E}+01$ & & $3.29 E+03$ & $3.70 \mathrm{E}+03$ & & $1.17 \mathrm{E}+03$ & $1.23 \mathrm{E}-02$ \\
\hline Sodium & & $8.43 E+03$ & & $1.25 \mathrm{E}+05$ & $1.02 \mathrm{E}+05$ & & $4.82 \mathrm{E}+04$ & $2.10 \mathrm{E}+00$ \\
\hline Sulfate & & NR & & $2.99 \mathrm{E}+03$ & $3.96 \mathrm{E}+03$ & & $1.06 \mathrm{E}+03$ & $1.10 \mathrm{E}-02$ \\
\hline TOC & & NR & & $3.90 \mathrm{E}+03$ & $1.63 \mathrm{E}+03$ & & $1.29 \mathrm{E}+03$ & $1.08 \mathrm{E}-01$ \\
\hline Oxalate & & $4.35 \mathrm{E}+02$ & & $9.15 \mathrm{E}+02$ & $1.32 \mathrm{E}+03$ & & $6.12 \mathrm{E}+02$ & $6.95 \mathrm{E}-03$ \\
\hline Zirconium & & NR & & NR & NR & & NR & NR \\
\hline $\begin{array}{l}\text { Radionuclides } \\
\text { (Ci/L) }\end{array}$ & none & & none & & & none & Total Tc(Ci) & \\
\hline${ }^{99} \mathrm{Tc}$ & & $9.37 \mathrm{E}-05$ & & $6.74 \mathrm{E}-05$ & 4.25E-05 & & & \\
\hline $\begin{array}{l}{ }^{99} \mathrm{Tc}(\mathrm{Ci}) \\
\text { Inventory }\end{array}$ & & $6.95 E+03$ & & $2.45 \mathrm{E}+03$ & $1.24 \mathrm{E}+02$ & & $9.53 E+03$ & \\
\hline Total Vol. (gal) & none & $1.96 \mathrm{E}+07$ & none & $9.62 \mathrm{E}+06$ & $7.70 \mathrm{E}+05$ & none & & \\
\hline Total Vol. (L) & & $7.42 \mathrm{E}+07$ & & $3.64 \mathrm{E}+07$ & $2.91 E+06$ & & $3.93 \mathrm{E}+07$ & \\
\hline
\end{tabular}


Table 3-2. (continued)

\begin{tabular}{|c|c|c|c|c|c|c|c|c|}
\hline Phase: & 1 & 2 & 3 & $4 a$ & $4 b$ & $4 \mathrm{c}$ & \multirow{2}{*}{$\begin{array}{c}\text { Vol } \\
\text { Weighted } \\
\text { Ave } \\
\end{array}$} & \multirow{2}{*}{$\begin{array}{c}\text { Vol } \\
\text { Weighted } \\
\text { Ave }\end{array}$} \\
\hline Interface $^{(*)}$ & $30 a$ & $30 a$ & $30 a$ & $30 a$ & $30 a$ & $30 a$ & & \\
\hline $\begin{array}{l}\text { Chemical } \\
\text { Comp. (mg/L) }\end{array}$ & none & & & & & & $\mathrm{mg} / \mathrm{L}$ & $\mathrm{M}$ \\
\hline Aluminum & & $2.40 \mathrm{E}+04$ & $2.60 \mathrm{E}+04$ & $3.53 E+04$ & $1.96 \mathrm{E}+04$ & $1.66 \mathrm{E}+04$ & $2.36 \mathrm{E}+04$ & 8.73E-01 \\
\hline Bismuth & & $2.53 \mathrm{E}+01$ & $1.08 \mathrm{E}+03$ & $9.27 \mathrm{E}+02$ & $1.76 \mathrm{E}+03$ & $5.72 \mathrm{E}+02$ & $1.15 \mathrm{E}+03$ & $5.51 \mathrm{E}-03$ \\
\hline Chlorine & & $2.13 \mathrm{E}+03$ & $2.40 \mathrm{E}+03$ & $1.78 \mathrm{E}+03$ & $1.07 \mathrm{E}+03$ & $6.34 \mathrm{E}+02$ & $1.28 \mathrm{E}+03$ & $3.60 \mathrm{E}-02$ \\
\hline Chromium & & $1.15 \mathrm{E}+03$ & $8.87 \mathrm{E}+02$ & $2.44 \mathrm{E}+03$ & $1.06 \mathrm{E}+03$ & $1.07 \mathrm{E}+03$ & $1.42 \mathrm{E}+03$ & 2.72E-02 \\
\hline Fluorine & & $4.93 \mathrm{E}+02$ & $3.45 \mathrm{E}+03$ & $1.87 \mathrm{E}+03$ & $3.80 \mathrm{E}+03$ & $3.36 \mathrm{E}+03$ & $3.06 \mathrm{E}+03$ & $1.61 \mathrm{E}-01$ \\
\hline Iron & & $1.39 \mathrm{E}+04$ & $7.74 \mathrm{E}+03$ & $2.62 \mathrm{E}+03$ & $3.13 E+03$ & $2.15 E+03$ & $3.42 \mathrm{E}+03$ & 6.12E-02 \\
\hline Nickel & & $5.97 \mathrm{E}+02$ & $7.93 \mathrm{E}+02$ & $4.83 \mathrm{E}+02$ & $3.35 \mathrm{E}+02$ & $1.56 \mathrm{E}+02$ & $3.71 \mathrm{E}+02$ & $6.31 \mathrm{E}-03$ \\
\hline Nitrate & & $4.41 \mathrm{E}+04$ & $5.74 \mathrm{E}+04$ & $3.02 E+04$ & $2.68 \mathrm{E}+04$ & $1.69 \mathrm{E}+04$ & $2.80 \mathrm{E}+04$ & 4.51E-01 \\
\hline Nitrite & & $1.04 \mathrm{E}+05$ & $1.22 \mathrm{E}+05$ & $8.71 \mathrm{E}+04$ & $1.05 \mathrm{E}+05$ & $6.58 \mathrm{E}+04$ & $9.20 \mathrm{E}+04$ & $2.00 \mathrm{E}+00$ \\
\hline Potassium & & $3.24 \mathrm{E}+03$ & $2.91 \mathrm{E}+03$ & $2.28 \mathrm{E}+03$ & $8.56 \mathrm{E}+02$ & $4.01 \mathrm{E}+02$ & $1.34 \mathrm{E}+03$ & $3.42 \mathrm{E}-02$ \\
\hline Phosphate & & $5.38 \mathrm{E}+03$ & $1.01 \mathrm{E}+04$ & $6.40 \mathrm{E}+03$ & $1.58 \mathrm{E}+04$ & $1.33 \mathrm{E}+04$ & $1.20 \mathrm{E}+04$ & $1.26 \mathrm{E}-01$ \\
\hline Sodium & & $1.16 \mathrm{E}+05$ & $1.33 \mathrm{E}+05$ & $9.77 \mathrm{E}+04$ & $9.43 \mathrm{E}+04$ & $6.29 \mathrm{E}+04$ & $9.10 \mathrm{E}+04$ & $3.95 \mathrm{E}+00$ \\
\hline Sulfate & & $4.75 \mathrm{E}+03$ & $6.05 \mathrm{E}+03$ & $4.04 \mathrm{E}+03$ & $9.50 \mathrm{E}+03$ & $8.31 \mathrm{E}+03$ & $7.39 \mathrm{E}+03$ & 7.70E-02 \\
\hline TOC & & $1.75 \mathrm{E}+03$ & $1.66 \mathrm{E}+03$ & $2.21 \mathrm{E}+03$ & $1.16 \mathrm{E}+03$ & $8.47 \mathrm{E}+02$ & $1.41 \mathrm{E}+03$ & $1.18 \mathrm{E}-01$ \\
\hline Oxalate & & $5.69 \mathrm{E}+03$ & $2.95 \mathrm{E}+03$ & $3.84 \mathrm{E}+03$ & $3.69 \mathrm{E}+03$ & $5.99 \mathrm{E}+03$ & $4.30 \mathrm{E}+03$ & $4.88 \mathrm{E}-02$ \\
\hline Zirconium & & $4.41 \mathrm{E}+02$ & $4.57 \mathrm{E}+03$ & $1.05 E+03$ & $1.49 \mathrm{E}+03$ & $2.88 \mathrm{E}+02$ & $1.26 \mathrm{E}+03$ & $1.39 \mathrm{E}-02$ \\
\hline $\begin{array}{l}\text { Radionuclides } \\
\text { (Ci/L) }\end{array}$ & none & & & & & & $\begin{array}{l}\text { Total Tc } \\
\text { (Ci) }\end{array}$ & \\
\hline${ }^{99} \mathrm{Tc}$ & & $9.69 \mathrm{E}-05$ & $9.96 \mathrm{E}-05$ & 5.27E-05 & $2.73 \mathrm{E}-05$ & 2.03E-05 & & \\
\hline $\begin{array}{l}{ }^{99} \mathrm{Tc}(\mathrm{Ci}) \\
\text { Inventory }\end{array}$ & & $9.72 \mathrm{E}+02$ & $2.22 \mathrm{E}+03$ & $4.43 E+03$ & $3.45 E+03$ & $1.58 \mathrm{E}+03$ & $1.26 \mathrm{E}+04^{(\mathrm{a})}$ & \\
\hline Total Vol. (gal) & none & $2.65 E+06$ & $5.89 E+06$ & $2.22 \mathrm{E}+07$ & $3.34 \mathrm{E}+07$ & $2.05 \mathrm{E}+07$ & & \\
\hline Total Vol. (L) & & $1.00 \mathrm{E}+07$ & $2.23 \mathrm{E}+07$ & $8.40 \mathrm{E}+07$ & $1.26 \mathrm{E}+08$ & $7.76 \mathrm{E}+07$ & $3.20 \mathrm{E}+08^{(\mathrm{a})}$ & \\
\hline
\end{tabular}


Table 3-2. (continued)

\begin{tabular}{|c|c|c|c|c|c|c|c|c|}
\hline Phase: & 1 & 2 & 3 & $4 a$ & $4 b$ & $4 c$ & \multirow{2}{*}{$\begin{array}{c}\text { Vol } \\
\text { Weighted } \\
\text { Ave } \\
\end{array}$} & \multirow{2}{*}{$\begin{array}{c}\text { Vol } \\
\text { Weighted } \\
\text { Ave }\end{array}$} \\
\hline Interface $^{(*)}$ & $33 a$ & $33 a$ & $33 a$ & $33 a$ & 33a & 33a & & \\
\hline $\begin{array}{l}\text { Chemical Comp. } \\
\text { (mg/L) }\end{array}$ & none & none & none & & & & $\mathrm{mg} / \mathrm{L}$ & M \\
\hline Aluminum & & & & $4.68 \mathrm{E}+03$ & $1.53 \mathrm{E}+03$ & $5.16 \mathrm{E}+02$ & $1.73 \mathrm{E}+03$ & 6.41E-02 \\
\hline Bismuth & & & & $5.65 \mathrm{E}+01$ & $1.05 E+02$ & $7.01 \mathrm{E}+01$ & $7.51 \mathrm{E}+01$ & 3.59E-04 \\
\hline Chlorine & & & & $3.25 E+03$ & $1.67 \mathrm{E}+03$ & $8.60 \mathrm{E}+02$ & $1.61 \mathrm{E}+03$ & $4.54 \mathrm{E}-02$ \\
\hline Chromium & & & & $5.53 \mathrm{E}+02$ & $6.43 \mathrm{E}+02$ & $2.35 \mathrm{E}+02$ & $4.05 \mathrm{E}+02$ & 7.79E-03 \\
\hline Fluorine & & & & $1.07 \mathrm{E}+03$ & $2.37 \mathrm{E}+03$ & $2.07 \mathrm{E}+03$ & $1.91 \mathrm{E}+03$ & $1.00 \mathrm{E}-01$ \\
\hline Iron & & & & $5.24 \mathrm{E}+01$ & $3.01 \mathrm{E}+01$ & $1.93 \mathrm{E}+01$ & $2.96 \mathrm{E}+01$ & $5.30 \mathrm{E}-04$ \\
\hline Nickel & & & & $1.69 \mathrm{E}+00$ & $1.21 \mathrm{E}-01$ & $1.42 \mathrm{E}-02$ & 4.32E-01 & 7.36E-06 \\
\hline Nitrate & & & & $8.18 \mathrm{E}+04$ & $3.69 \mathrm{E}+04$ & $2.50 \mathrm{E}+04$ & $4.11 \mathrm{E}+04$ & 6.63E-01 \\
\hline Nitrite & & & & $1.46 \mathrm{E}+05$ & $1.36 \mathrm{E}+05$ & $1.01 \mathrm{E}+05$ & $1.20 \mathrm{E}+05$ & $2.60 \mathrm{E}+00$ \\
\hline Potassium & & & & $3.09 \mathrm{E}+03$ & $1.42 \mathrm{E}+03$ & $4.81 \mathrm{E}+02$ & $1.31 \mathrm{E}+03$ & 3.36E-02 \\
\hline Phosphate & & & & $4.28 \mathrm{E}+03$ & $6.10 \mathrm{E}+03$ & $6.90 \mathrm{E}+03$ & $6.10 \mathrm{E}+03$ & 6.42E-02 \\
\hline Sodium & & & & $1.56 \mathrm{E}+05$ & $1.16 \mathrm{E}+05$ & $7.58 \mathrm{E}+04$ & $1.04 \mathrm{E}+05$ & $4.52 \mathrm{E}+00$ \\
\hline Sulfate & & & & $6.73 E+03$ & $9.33 \mathrm{E}+03$ & $9.08 \mathrm{E}+03$ & $8.59 \mathrm{E}+03$ & 8.95E-02 \\
\hline TOC & & & & $1.69 \mathrm{E}+03$ & $1.65 \mathrm{E}+03$ & $9.38 \mathrm{E}+02$ & $1.28 \mathrm{E}+03$ & $1.07 \mathrm{E}-01$ \\
\hline Oxalate & & & & $1.15 \mathrm{E}+03$ & $1.61 \mathrm{E}+03$ & $1.63 \mathrm{E}+03$ & $1.51 \mathrm{E}+03$ & 1.72E-02 \\
\hline Zirconium & & & & NR & NR & NR & NR & NR \\
\hline $\begin{array}{l}\text { Radionuclides } \\
\text { (Ci/L) }\end{array}$ & none & none & none & & & & $\begin{array}{l}\text { Total Tc } \\
\text { (Ci) }\end{array}$ & \\
\hline${ }^{99} \mathrm{Tc}$ & & & & $1.08 \mathrm{E}-04$ & 4.69E-05 & $2.56 \mathrm{E}-05$ & & \\
\hline $\begin{array}{l}{ }^{99} \mathrm{Tc}(\mathrm{Ci}) \\
\text { Inventory }\end{array}$ & & & & $2.85 \mathrm{E}+03$ & $1.24 \mathrm{E}+03$ & $1.53 \mathrm{E}+03$ & $5.62 \mathrm{E}+03$ & \\
\hline $\begin{array}{l}\text { Total Volume } \\
\text { (gal) }\end{array}$ & none & none & none & $6.97 \mathrm{E}+06$ & $6.97 \mathrm{E}+06$ & $1.58 \mathrm{E}+07$ & & \\
\hline $\begin{array}{l}\text { Total Volume } \\
\text { (L) }\end{array}$ & & & & $2.64 \mathrm{E}+07$ & $2.64 \mathrm{E}+07$ & $5.98 \mathrm{E}+07$ & $1.13 E+08$ & \\
\hline
\end{tabular}


Table 3-2. (continued)

\begin{tabular}{|c|c|c|c|c|c|c|c|c|}
\hline Phase: & 1 & 2 & 3 & $4 a$ & $4 b$ & $4 c$ & & \\
\hline Interface $^{(*)}$ & $34 a$ & $34 a$ & $34 a$ & $34 a$ & $34 a$ & $34 a$ & Ave & Ave \\
\hline $\begin{array}{l}\text { Chemical } \\
\text { Comp. (mg/L) }\end{array}$ & none & none & & & & & $\mathrm{mg} / \mathrm{L}$ & M \\
\hline Aluminum & & & $2.36 \mathrm{E}+04$ & $3.44 \mathrm{E}+04$ & $2.15 \mathrm{E}+04$ & $1.56 \mathrm{E}+04$ & $2.34 \mathrm{E}+04$ & 8.67E-01 \\
\hline Bismuth & & & $4.68 \mathrm{E}+02$ & $9.87 \mathrm{E}+02$ & $1.77 \mathrm{E}+03$ & $5.63 \mathrm{E}+02$ & $1.14 \mathrm{E}+03$ & $5.47 \mathrm{E}-03$ \\
\hline Chlorine & & & $2.14 \mathrm{E}+03$ & $1.94 \mathrm{E}+03$ & $1.03 \mathrm{E}+03$ & $7.65 \mathrm{E}+02$ & $1.27 \mathrm{E}+03$ & $3.58 \mathrm{E}-02$ \\
\hline Chromium & & & $9.44 \mathrm{E}+02$ & $2.31 \mathrm{E}+03$ & $1.14 \mathrm{E}+03$ & $1.02 \mathrm{E}+03$ & $1.40 \mathrm{E}+03$ & $2.70 \mathrm{E}-02$ \\
\hline Fluorine & & & $2.49 \mathrm{E}+03$ & $1.78 \mathrm{E}+03$ & $3.70 \mathrm{E}+03$ & $3.41 \mathrm{E}+03$ & $3.03 E+03$ & $1.60 \mathrm{E}-01$ \\
\hline Iron & & & $9.91 \mathrm{E}+03$ & $3.45 \mathrm{E}+03$ & $3.25 \mathrm{E}+03$ & $1.99 \mathrm{E}+03$ & $3.39 \mathrm{E}+03$ & $6.07 \mathrm{E}-02$ \\
\hline Nickel & & & $6.71 \mathrm{E}+02$ & $4.98 \mathrm{E}+02$ & $3.90 \mathrm{E}+02$ & $1.40 \mathrm{E}+02$ & $3.68 \mathrm{E}+02$ & $6.26 \mathrm{E}-03$ \\
\hline Nitrate & & & $5.02 \mathrm{E}+04$ & $3.45 \mathrm{E}+04$ & $2.48 \mathrm{E}+04$ & $2.02 \mathrm{E}+04$ & $2.78 \mathrm{E}+04$ & $4.48 \mathrm{E}-01$ \\
\hline Nitrite & & & $1.10 \mathrm{E}+05$ & $9.20 \mathrm{E}+04$ & $9.57 \mathrm{E}+04$ & $7.92 \mathrm{E}+04$ & $9.11 \mathrm{E}+04$ & $1.98 \mathrm{E}+00$ \\
\hline Potassium & & & $3.07 \mathrm{E}+03$ & $2.46 \mathrm{E}+03$ & $8.83 \mathrm{E}+02$ & $4.63 \mathrm{E}+02$ & $1.33 \mathrm{E}+03$ & 3.39E-02 \\
\hline Phosphate & & & $7.16 \mathrm{E}+03$ & $7.05 \mathrm{E}+03$ & $1.48 \mathrm{E}+04$ & $1.36 \mathrm{E}+04$ & $1.19 \mathrm{E}+04$ & $1.25 \mathrm{E}-01$ \\
\hline Sodium & & & $1.21 \mathrm{E}+05$ & $1.04 \mathrm{E}+05$ & $8.83 \mathrm{E}+04$ & $7.21 \mathrm{E}+04$ & $9.01 \mathrm{E}+04$ & $3.92 \mathrm{E}+00$ \\
\hline Sulfate & & & $5.25 \mathrm{E}+03$ & $4.34 \mathrm{E}+03$ & $8.18 \mathrm{E}+03$ & $9.46 \mathrm{E}+03$ & $7.33 \mathrm{E}+03$ & 7.63E-02 \\
\hline TOC & & & $1.68 \mathrm{E}+03$ & $2.24 \mathrm{E}+03$ & $1.10 \mathrm{E}+03$ & $9.78 \mathrm{E}+02$ & $1.41 \mathrm{E}+03$ & $1.17 \mathrm{E}-01$ \\
\hline Oxalate & & & $4.14 \mathrm{E}+03$ & $3.85 \mathrm{E}+03$ & $3.58 \mathrm{E}+03$ & $5.65 \mathrm{E}+03$ & $4.26 \mathrm{E}+03$ & 4.84E-02 \\
\hline Zirconium & & & $3.27 \mathrm{E}+03$ & $1.09 \mathrm{E}+03$ & $1.73 \mathrm{E}+03$ & $2.62 \mathrm{E}+02$ & $1.26 \mathrm{E}+03$ & $1.38 \mathrm{E}-02$ \\
\hline $\begin{array}{l}\text { Radionuclides } \\
\text { (Ci/L) }\end{array}$ & none & none & & & & & $\begin{array}{l}\text { Total Tc } \\
\text { (Ci) }\end{array}$ & \\
\hline${ }^{99} \mathrm{Tc}$ & & & $9.53 \mathrm{E}-05$ & $6.15 \mathrm{E}-05$ & $2.65 \mathrm{E}-05$ & $2.25 \mathrm{E}-05$ & & \\
\hline $\begin{array}{l}{ }^{99} \mathrm{Tc}(\mathrm{Ci}) \\
\text { Inventory }\end{array}$ & & & $2.02 \mathrm{E}+03$ & $5.24 \mathrm{E}+03$ & $3.37 \mathrm{E}+03$ & $2.01 \mathrm{E}+03$ & $1.26 \mathrm{E}+04^{(\mathrm{a})}$ & \\
\hline $\begin{array}{l}\text { Total Volume } \\
\text { (gal) }\end{array}$ & none & none & $5.60 \mathrm{E}+06$ & $2.25 \mathrm{E}+07$ & $3.36 \mathrm{E}+07$ & $2.36 \mathrm{E}+07$ & & \\
\hline $\begin{array}{l}\text { Total Volume } \\
\text { (L) }\end{array}$ & & & $2.12 \mathrm{E}+07$ & $8.52 \mathrm{E}+07$ & $1.27 \mathrm{E}+08$ & $8.93 \mathrm{E}+07$ & $3.23 E+08^{(a)}$ & \\
\hline
\end{tabular}

${ }^{(*)}$ see Table 3-1 for definition of interfaces. ${ }^{(a)}$ Interfaces 30(a) and 34(a) are essentially the same waste stream as it enters and exits TWCS. Only very minor changes in chemical composition and total volume are predicted by the One System flowsheet projections. ${ }^{99}$ Tc inventory that enters (interface 30a) and then exits (interface 34a) is predicted to be the same.

(a) none $=$ no waste stream was generated during this WTP mission phase.

${ }^{(b)} \mathrm{NR}=$ not reported and assumed to be insignificant. 
4 to $5 \mathrm{M}$ (Duncan et al. 2011). As shown in Table 3-3 the tank waste Na composition sent to the various "pre-treatment" facilities as a function of phase (time) varies between 0.37 to $6.78 \mathrm{M} \mathrm{Na}$. The Phase 2 DST waste going to the LAWPS facility may be too low in Na to be processed to remove TcO4- using SuperLig 639 without adding additional caustic, or concentrating the solution by evaporation. Further, most of the final Phase 4C wastes have Na concentrations at or below 3.3 M, which may also require additional Na addition. Thus many of the waste streams to be transferred to the LAWPS, TWCS, and the PT facilities may not exist as an ideal saline solution to use SuperLig 639 to remove pertechnetate from solution. One study, Rapko et al. (2003), evaluated pertechnetate sorption properties of SuperLig 639 as a function of Na concentration and total ionic strength. They found a strong linear correlation for the pertechnetate Kd (sorption distribution value) to both the total sodium concentration and to the solution's ionic strength. Rapko et al. (2003)'s data are shown in Table 3-4 and Figure 3-2

Table 3-3. Tank Waste Na Composition (in M) as a Function of Phase (Time) and Pre-Treatment Facility

\begin{tabular}{|l|c|c|c|c|c|c|}
\hline Waste goes (from $\rightarrow$ to) & Phase 1 & Phase 2 & Phase 3 & Phase 4a & Phase 4B & Phase 4C \\
\hline $\begin{array}{l}\text { 27a (DST waste to } \\
\text { LAWPS) }\end{array}$ & none & 0.37 & None & 5.43 & 4.43 & none \\
\hline $\begin{array}{l}\text { 30a (DST waste to } \\
\text { TWCS) }\end{array}$ & none & 5.04 & 5.78 & 4.25 & 4.10 & 2.73 \\
\hline $\begin{array}{l}\text { 33a (DST waste to } \\
\text { WTP PT) }\end{array}$ & none & none & None & 6.78 & 5.04 & 3.30 \\
\hline $\begin{array}{l}\text { 34a (TWCS waste to } \\
\text { WTP PT) }\end{array}$ & none & none & 5.26 & 4.52 & 3.84 & 3.13 \\
\hline
\end{tabular}

Highlighted cells indicate that the Na concentration in this particular waste stream may be too low to effectively remove the pertechnetate from DST tank wastes using SuperLig 639.

Table 3-4 SuperLig 639 Pertechnetate Sorption $\mathrm{K}_{\mathrm{d}}(\mathrm{mL} / \mathrm{g})$ as a Function of Na Concentration (M)

\begin{tabular}{|cccc|}
\hline & $\begin{array}{c}\text { Equilibrium } \mathrm{NO}_{3}{ }^{-} / \mathrm{TcO}_{4}{ }^{-} \\
\text {Total } \mathrm{Na}(\mathrm{M})\end{array}$ & Ave $\mathrm{K}_{\mathrm{d}}$ & Std Dev. Of Ave. $\mathrm{K}_{\mathrm{d}}$ \\
\hline 5.028 & 223 & 1997 & 103 \\
1.028 & 49.4 & 351 & 13 \\
0.528 & 31.5 & 203 & 20 \\
0.128 & 19.2 & 71 & 3 \\
0.028 & 13.8 & 12 & 3 \\
Nitrate and hydroxide were fixed at 0.018 and $0.01 \mathrm{M}$, respectively. Na was varied by adding NaCl. \\
\hline
\end{tabular}

Table 3-4 shows that the pertechnetate association with SuperLig 639 (as quantified by the $\mathrm{K}_{\mathrm{d}}$ ) drops quickly as total Na concentration is lowered from $5 \mathrm{M}$. Thus the efficiency of removing pertechnetate from dilute solutions such as $<1 \mathrm{M}$ Na will be much lower than for solutions in the ideal range of 4 to $5 \mathrm{M}$ Na. 


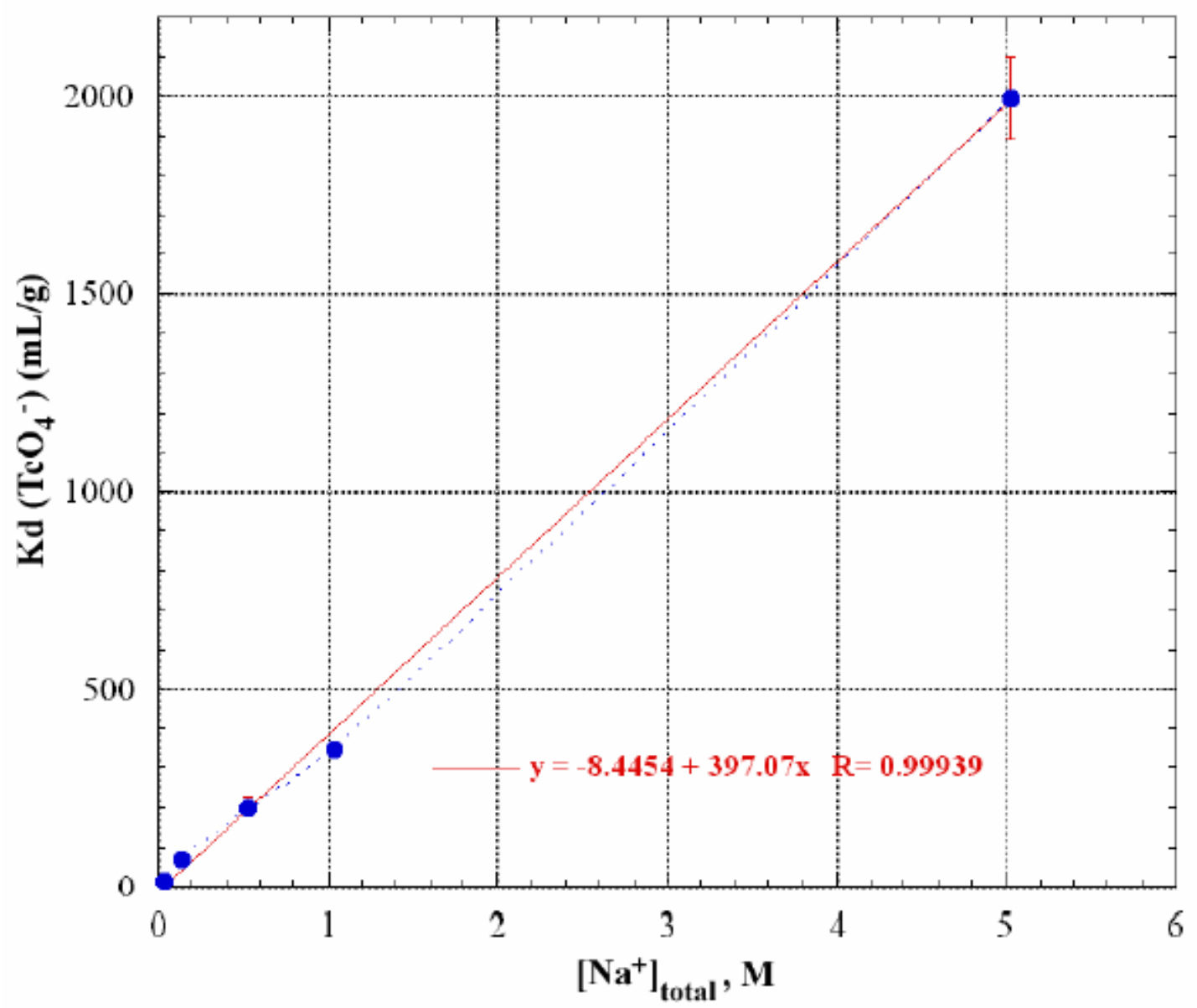

Figure 3-2 Plot of Pertechnetate Kd Value as a Function of Solution Na Concentration (M) with 0.018 M NO3 and $0.01 \mathrm{M} \mathrm{OH}$

Further, all past small-scale testing of SuperLig 639 for removal of pertechnetate was performed on DST supernates that had first been processed to remove ${ }^{137} \mathrm{Cs}$ so that the pertechnetate removal could be done outside of hot-cells. For the DFLAW and LAW feed waste streams (27a and 33a) the baseline flow sheet will include ${ }^{137} \mathrm{Cs}$ removal such that only the SuperLig 639 processing step would need to be added to the current WTP mission to effect pertechnetate removal. However, the slurry waste streams (30a --going from DSTs to TWCS---and 34a going from TWCS to WTP PT facility) contain between 6.4 and $8.9 \mathrm{wt} \%$ suspended solids that would have to be filtered out before SuperLig 639 resin could be used to remove pertechnetate. Essentially these two interfaces describe the same slurry waste as it enters and then leaves TWCS. In addition, ${ }^{137} \mathrm{Cs}$ removal is not currently part of the operations to be performed in TWCS, thus the $\mathrm{TcO}_{4}{ }^{-}$removal performance of SuperLig 639 on tank waste prior to removal of ${ }^{137} \mathrm{Cs}$ is unknown. Radiation damage on the SuperLig 639 material from the high gamma ray dose from ${ }^{137} \mathrm{Cs}$ is a likely issue.

The volume of tank waste that is transferred from the DST directly to pre-treatment facilities includes waste from interfaces 27a, 30a, and 33a. Interface 34a transfers tank slurry waste from the TWCS to the WTP Pretreatment Facility during Phases 3 and 4 so does not directly get waste from the DSTs. Table 3-5 sums the volume of waste sent from the DSTs and the Tc inventory within the waste transferred from the DSTs. The total volume of tank waste estimated, by the HTWOS computer code for the entire WTP 
mission, as being transferred directly to pre-treatment facilities is almost 550 million liters and the estimated Tc inventory is 27,800 curies. This Tc inventory estimate is about $5 \%$ larger than the total estimated (26,500 Ci) to be in the Hanford tanks in 2014 (see Serne et al., 2014 and references within). This slightly larger Tc inventory may be caused by WTP secondary waste streams that are recycled back to DSTs during operation of the melters. Regardless, the volume of waste transferred to the pre-treatment facilities from the DSTs, 550 million liters, is large and the costs for SuperLig 639 resin that would be used to remove the pertechnetate from these waste streams might be high. Small-scale laboratory tests (see for example Burgeson et al. 2004 a,b) on SuperLig 639 for removal of pertechnetate from DST supernate suggest that the resin can treat between 360 to 500 bed volumes of DST supernatant before the pertechnetate breakthrough reaches 50\%. Upon reaching 50\% breakthrough, the resins should be regenerated using distilled water at $\sim 65^{\circ} \mathrm{C}$. Using these SuperLig 639 pertechnetate removal efficiency values, it would take between 1.0 million and 1.5 million liters of SuperLig 639 resin to process the $\sim 550$ million liters of tank liquid waste transferred to pretreatment facilities if the resin was used only once. However, it is known that the SuperLig 639 resin can be readily re-generated (stripped of the bound pertechnetate and reused). It is reported that $\geq 50$ loading cycles are expected for LAW feed (Duncan et al. 2011). If we assume that the resin can be regenerated 50 times before it loses its efficiency from radiation or chemical damage, then the total volume of SuperLig 639 resin needed to remove pertechnetate from the 550 million liters of tank waste would be between 22,000 and 30,000 liters. Burgeson et al. (2004a,b) found that the bed density of SuperLig 639 packed resin beds was $0.5 \mathrm{~g} / \mathrm{mL}$ or $0.5 \mathrm{~kg} / \mathrm{L}$. Thus between 11,000 and 15,000 kg of the SuperLig 639 resin would be a reasonable estimate of the mass of SuperLig 639 that might be required to process all the tank waste to remove pertechnetate. Also recall that SuperLig 639 does not remove non-pertechnetate species from tank waste (see review discussion in Serne et al., 2014; Rapko et al. 2013a, b). Non-pertechnetate species would require additional treatment; perhaps oxidizing the non-pertechnetate species (they are known to be in lower oxidation states than $\mathrm{TcO}_{4}^{-}$) but there is little data available on how easy it would be to convert nonpertechnetate species to pertechnetate.

Table 3-5. Overall Volume and Tc Inventory (Ci) Transferred From DSTs to PT Facilities

\begin{tabular}{|l|c|c|c|c|c|}
\hline \multicolumn{7}{|c|}{ From DSTs to Pretreatment Facilities } \\
\hline Into: & Interface & vol (gal) & vol (L) & Tc (Ci/L) & Tc (Ci) \\
\hline LAWPS & $27 \mathrm{a}$ & $3.00 \mathrm{E}+07$ & $1.14 \mathrm{E}+08$ & $8.40 \mathrm{E}-05$ & $9.54 \mathrm{E}+03$ \\
\hline LAW PT & $33 \mathrm{a}$ & $2.98 \mathrm{E}+07$ & $1.13 \mathrm{E}+08$ & $4.99 \mathrm{E}-05$ & $5.63 \mathrm{E}+03$ \\
\hline TWCS & $30 \mathrm{a}$ & $8.46 \mathrm{E}+07$ & $3.20 \mathrm{E}+08$ & $3.95 \mathrm{E}-05$ & $1.26 \mathrm{E}+04$ \\
\hline & Totals & $\mathbf{1 . 4 4 E + 0 8}$ & $\mathbf{5 . 4 7 E}+\mathbf{0 8}$ & & $2.78 \mathrm{E}+\mathbf{0 4}$ \\
\hline
\end{tabular}

Although removing ${ }^{99}$ Tc from the very front end of the WTP flowsheet and creating a separate low volume Tc-only waste form would be desirable, given the following issues it may not be practical to perform the Tc removal at the front end of WTP. Issues include the large mass of SuperLig 639 resin that would be required, the lower than optimum (4 to $5 \mathrm{M}$ ) alkali-metal concentrations in much of the tank waste, presence of suspended solids, and high ${ }^{137} \mathrm{Cs}$ content in some of the tank waste locations discussed and the fact that SuperLig 639 only removes the $\mathrm{TcO}_{4}{ }^{-}$species. 
If "treated" tank waste was going to have Tc removed at the back-end of treatment just before being sent to the melters or in a new (not part of the current design) operation performed at the melters before being added to the melters, the key interfaces that would be considered are shown in Table 3-6.

Table 3-6. Interfaces Between Treated Tank Waste and Melter Facilities

\begin{tabular}{|c|c|c|c|c|}
\hline Interface & $\begin{array}{c}\text { Interface } \\
\text { Name }\end{array}$ & From & To & Primary Flow \\
\hline 28 & DF LAW & LAWPS & LAW Melters & LAW \\
\hline $41 \mathrm{a}$ & LAW & PT & LAW Melters & LAW \\
\hline 31 & DF HLW & TWCS & HLW Melters & HLW \\
\hline $35 a$ & HLW & PT & HLW Melters & HLW \\
\hline 45 & PT to SLAW & PT & SLAW Melters & LAW \\
\hline 46 & DF SLAW & LAWPS & SLAW Melters & LAW \\
\hline
\end{tabular}

Table 3-7 lists the volume weighted masses of key waste stream chemicals in units of $\mathrm{mg} / \mathrm{L}$ and molarity (M) and volume weighted Tc inventory in curies for all 4 operational phases of the WTP mission for treated liquid wastes that will be sent to the melters is versus WTP operational phase (time). Because the volume weighted averages do not honor the individual durations of the phases we have also parsed out the Na composition by phases so that one can see what the average Na composition is versus time. As mentioned Na concentration is important because the SuperLig 639 resin (to date the most mature technology for Tc separation from LAW) works best when the sodium (actually total alkali metal) concentration is about 4 to $5 \mathrm{M}$ (Duncan et al 2011). Hamm et al. (2013) presents two numerical models/codes that predict the performance of SuperLig 639 for removing pertechnetate from Hanford tank wastes. Two models are described 1) A thermodynamic isotherm model, based on experimental data, that predicts $\mathrm{TcO}_{4}{ }^{-}$sorption as a function of solution composition and temperature and 2) A column model that uses the isotherm calculated by the first model to simulate the performance of a full-scale sorption process. The isotherm model provides a synthesis of experimental data collected from many different sources to give a best estimate prediction of the behavior of the pertechnetate-SuperLig 639 system and an estimate of the uncertainty in this prediction. The column model provides a prediction of the expected performance of the full-scale process by determining the volume of waste solution that can be processed based on SuperLig 639 design parameters such as column size, flow rate and resin physical properties.

As shown in Table 3-8, the tank waste Na composition sent to various "pre-treatment" facilities as a function of phase (time) varies between 0.26 and 7.96 M Na. The waste going from PT to the HLW melter is likely too low in $\mathrm{Na}$ to be effectively processed to remove $\mathrm{TcO}_{4}{ }^{-}$using SuperLig 639 without adding additional caustic, or concentrating the solution by evaporation. The treated waste leaving PT and going to the LAW and SLAW melters has Na concentrations above 4 to $5 \mathrm{M}$, which is the range of Na concentrations used in the SuperLig 639 bench-scale tests that successfully removed pertechnetate. 
Table 3-7. Volumes, Tc Concentrations and Inventory, and Chemical Concentrations of Treated Tank Waste Sent to Melters

\begin{tabular}{|c|c|c|c|c|c|c|c|c|}
\hline & Phase 1 & Phase 2 & Phase 3 & Phase 4a & Phase 4B & Phase 4C & $\begin{array}{c}\text { Vol } \\
\text { Weighted } \\
\text { Ave }\end{array}$ & $\begin{array}{c}\text { Vol } \\
\text { Weighted } \\
\text { Ave }\end{array}$ \\
\hline Interface ${ }^{*}$ & 28 & 28 & 28 & 28 & 28 & 28 & $\mathrm{mg} / \mathrm{L}$ & $M$ \\
\hline $\begin{array}{l}\text { Chemical } \\
\text { Components } \\
\text { (mg/L) }\end{array}$ & none & & none & none & none & none & & \\
\hline Aluminum & & $4.01 \mathrm{E}+03$ & & & & & $4.01 \mathrm{E}+03$ & $1.49 \mathrm{E}-01$ \\
\hline Bismuth & & $2.61 \mathrm{E}+01$ & & & & & $2.61 \mathrm{E}+01$ & $1.25 \mathrm{E}-04$ \\
\hline Chlorine & & $2.27 E+03$ & & & & & $2.27 \mathrm{E}+03$ & $6.40 \mathrm{E}-02$ \\
\hline Chromium & & $3.97 \mathrm{E}+02$ & & & & & $3.97 \mathrm{E}+02$ & $7.64 \mathrm{E}-03$ \\
\hline Fluorine & & $3.95 E+02$ & & & & & $3.95 \mathrm{E}+02$ & $2.08 \mathrm{E}-02$ \\
\hline Iron & & $5.00 \mathrm{E}+01$ & & & & & $5.00 \mathrm{E}+01$ & 8.95E-04 \\
\hline Nickel & & $1.55 E+00$ & & & & & $1.55 \mathrm{E}+00$ & 2.64E-05 \\
\hline Nitrate & & $6.31 \mathrm{E}+04$ & & & & & $6.31 \mathrm{E}+04$ & $1.02 \mathrm{E}+00$ \\
\hline Nitrite & & $1.10 \mathrm{E}+05$ & & & & & $1.10 \mathrm{E}+05$ & $2.39 \mathrm{E}+00$ \\
\hline Potassium & & $3.45 \mathrm{E}+03$ & & & & & $3.45 \mathrm{E}+03$ & 8.82E-02 \\
\hline Phosphate & & $3.31 \mathrm{E}+03$ & & & & & $3.31 \mathrm{E}+03$ & $3.48 \mathrm{E}-02$ \\
\hline Sodium & & $1.29 \mathrm{E}+05$ & & & & & $1.29 \mathrm{E}+05$ & $5.61 \mathrm{E}+00$ \\
\hline Sulfate & & $4.83 E+03$ & & & & & $4.83 \mathrm{E}+03$ & 5.03E-02 \\
\hline TOC & & $1.56 \mathrm{E}+03$ & & & & & $1.56 \mathrm{E}+03$ & $1.30 \mathrm{E}-01$ \\
\hline Oxalate & & $9.63 \mathrm{E}+02$ & & & & & $9.63 \mathrm{E}+02$ & 1.09E-02 \\
\hline Zirconium & & NR & & & & & & \\
\hline $\begin{array}{l}\text { Radionuclides } \\
\text { (Ci/L) }\end{array}$ & none & & none & none & none & none & & \\
\hline${ }^{99} \mathrm{Tc}$ & & 9.39E-05 & & & & & Total Tc(Ci) & \\
\hline $\begin{array}{l}{ }^{99} \mathrm{Tc}(\mathrm{Ci}) \\
\text { Inventory }\end{array}$ & & $6.93 \mathrm{E}+03$ & & & & & $6.93 E+03$ & \\
\hline $\begin{array}{l}\text { Total Volume } \\
\text { (gal) }\end{array}$ & none & $1.95 \mathrm{E}+07$ & & & & & Total Vol. (L) & \\
\hline $\begin{array}{l}\text { Total Volume } \\
\text { (L) }\end{array}$ & & $7.38 \mathrm{E}+07$ & & & & & $7.38 \mathrm{E}+07$ & \\
\hline
\end{tabular}


Table 3-7. (continued)

\begin{tabular}{|c|c|c|c|c|c|c|c|c|}
\hline & Phase 1 & Phase 2 & Phase 3 & Phase 4a & Phase 4B & Phase 4C & $\begin{array}{c}\text { Vol } \\
\text { Weighted } \\
\text { Ave }\end{array}$ & $\begin{array}{c}\text { Vol } \\
\text { Weighted } \\
\text { Ave }\end{array}$ \\
\hline Interface ${ }^{*}$ & $41 a$ & $41 a$ & $41 a$ & $41 a$ & $41 a$ & $41 a$ & $\mathrm{mg} / \mathrm{L}$ & M \\
\hline $\begin{array}{l}\text { Chemical } \\
\text { Components } \\
\text { (mg/L) }\end{array}$ & none & none & & & & & & \\
\hline Aluminum & & & $1.78 \mathrm{E}+04$ & $1.72 \mathrm{E}+04$ & $1.31 \mathrm{E}+04$ & $1.31 \mathrm{E}+04$ & $1.50 \mathrm{E}+04$ & 5.57E-01 \\
\hline Bismuth & & & $9.41 \mathrm{E}+01$ & $1.52 \mathrm{E}+02$ & $1.72 \mathrm{E}+02$ & $1.65 \mathrm{E}+02$ & $1.55 \mathrm{E}+02$ & $7.42 \mathrm{E}-04$ \\
\hline Chlorine & & & $2.59 \mathrm{E}+03$ & $2.84 \mathrm{E}+03$ & $1.72 \mathrm{E}+03$ & $1.44 \mathrm{E}+03$ & $2.14 \mathrm{E}+03$ & $6.04 \mathrm{E}-02$ \\
\hline Chromium & & & $7.43 \mathrm{E}+02$ & $1.51 \mathrm{E}+03$ & $1.23 \mathrm{E}+03$ & $1.06 \mathrm{E}+03$ & $1.24 \mathrm{E}+03$ & 2.38E-02 \\
\hline Fluorine & & & $2.78 \mathrm{E}+03$ & $2.27 \mathrm{E}+03$ & $5.00 \mathrm{E}+03$ & $5.77 \mathrm{E}+03$ & $3.99 \mathrm{E}+03$ & $2.10 \mathrm{E}-01$ \\
\hline Iron & & & $1.65 \mathrm{E}+02$ & $1.77 \mathrm{E}+02$ & $1.74 \mathrm{E}+02$ & $1.46 \mathrm{E}+02$ & $1.67 \mathrm{E}+02$ & $3.00 \mathrm{E}-03$ \\
\hline Nickel & & & $7.03 \mathrm{E}+00$ & $7.00 \mathrm{E}+00$ & $5.02 \mathrm{E}+00$ & $4.66 \mathrm{E}+00$ & $5.84 \mathrm{E}+00$ & $9.96 \mathrm{E}-05$ \\
\hline Nitrate & & & $3.98 \mathrm{E}+04$ & $4.37 \mathrm{E}+04$ & $3.18 \mathrm{E}+04$ & $3.06 \mathrm{E}+04$ & $3.66 \mathrm{E}+04$ & $5.90 \mathrm{E}-01$ \\
\hline Nitrite & & & $1.04 \mathrm{E}+05$ & $1.09 \mathrm{E}+05$ & $1.29 \mathrm{E}+05$ & $1.28 \mathrm{E}+05$ & $1.19 \mathrm{E}+05$ & $2.59 \mathrm{E}+00$ \\
\hline Potassium & & & $2.69 \mathrm{E}+03$ & $2.28 \mathrm{E}+03$ & $1.22 \mathrm{E}+03$ & $6.53 \mathrm{E}+02$ & $1.61 \mathrm{E}+03$ & 4.13E-02 \\
\hline Phosphate & & & $5.91 \mathrm{E}+03$ & $6.17 \mathrm{E}+03$ & $1.52 \mathrm{E}+04$ & $1.78 \mathrm{E}+04$ & $1.17 \mathrm{E}+04$ & 1.23E-01 \\
\hline Sodium & & & $1.83 \mathrm{E}+05$ & $1.82 \mathrm{E}+05$ & $1.79 \mathrm{E}+05$ & $1.77 \mathrm{E}+05$ & $1.80 \mathrm{E}+05$ & $7.83 \mathrm{E}+00$ \\
\hline Sulfate & & & $4.37 \mathrm{E}+03$ & $4.71 \mathrm{E}+03$ & $9.96 \mathrm{E}+03$ & $1.55 \mathrm{E}+04$ & $8.84 \mathrm{E}+03$ & $9.21 \mathrm{E}-02$ \\
\hline TOC & & & $1.43 \mathrm{E}+03$ & $1.77 \mathrm{E}+03$ & $1.36 \mathrm{E}+03$ & $1.35 \mathrm{E}+03$ & $1.51 \mathrm{E}+03$ & $1.26 \mathrm{E}-01$ \\
\hline Oxalate & & & $3.44 \mathrm{E}+03$ & $2.64 \mathrm{E}+03$ & $3.62 \mathrm{E}+03$ & $6.83 E+03$ & $4.02 \mathrm{E}+03$ & 4.57E-02 \\
\hline Zirconium & & & NR & NR & NR & NR & NR & NR \\
\hline $\begin{array}{l}\text { Radionuclides } \\
\text { (Ci/L) }\end{array}$ & none & none & & & & & & \\
\hline${ }^{99} \mathrm{Tc}$ & & & $1.36 \mathrm{E}-04$ & 1.19E-04 & 5.09E-05 & 4.85E-05 & Total Tc(Ci) & \\
\hline $\begin{array}{l}{ }^{99} \mathrm{Tc}(\mathrm{Ci}) \\
\text { Inventory }\end{array}$ & & & $2.52 \mathrm{E}+03$ & $7.48 \mathrm{E}+03$ & $2.74 \mathrm{E}+03$ & $2.06 \mathrm{E}+03$ & $1.48 \mathrm{E}+04$ & \\
\hline $\begin{array}{l}\text { Total Volume } \\
\text { (gal) }\end{array}$ & & & $4.90 \mathrm{E}+06$ & $1.66 \mathrm{E}+07$ & $1.42 \mathrm{E}+07$ & $1.12 \mathrm{E}+07$ & Total Vol. (L) & \\
\hline $\begin{array}{l}\text { Total Volume } \\
\text { (L) }\end{array}$ & & & $1.85 \mathrm{E}+07$ & $6.28 \mathrm{E}+07$ & $5.38 \mathrm{E}+07$ & $4.24 \mathrm{E}+07$ & $1.78 \mathrm{E}+08$ & \\
\hline
\end{tabular}


Table 3-7. (continued)

\begin{tabular}{|l|l|l|l|l|l|l|c|c|}
\hline & Phase 1 & Phase 2 & Phase 3 & Phase 4a & Phase 4B & Phase 4C & $\begin{array}{c}\text { Vol } \\
\text { Weighted } \\
\text { Ave }\end{array}$ & $\begin{array}{c}\text { Vol } \\
\text { Weighted } \\
\text { Ave }\end{array}$ \\
\hline Interface* & 31 & 31 & 31 & 31 & 31 & 31 & mg/L & M \\
\hline $\begin{array}{l}\text { Chemical } \\
\text { Components } \\
\text { (mg/L) }\end{array}$ & No Data & No Data & No Data & No Data & No Data & No Data & No Data & No Data \\
\hline $\begin{array}{l}\text { Radionuclides } \\
\text { (Ci/L) }\end{array}$ & No Data & No Data & No Data & No Data & No Data & No Data & No Data & No Data \\
\hline${ }^{99}$ Tc & & & & & & & Total Tc(Ci) & \\
\hline $\begin{array}{l}\text { 99 Tc (Ci) } \\
\text { Inventory }\end{array}$ & & & & & & No Data & \\
\hline $\begin{array}{l}\text { Total Volume } \\
\text { (gal) }\end{array}$ & No Data & No Data & No Data & No Data & No Data & No Data & Total Vol. (L) & \\
\hline $\begin{array}{l}\text { Total Volume } \\
\text { (L) }\end{array}$ & & & & & & & No Data & \\
\hline
\end{tabular}

The One-System flowsheet projections do not track waste from the TWCS to the HLW melters (Interface 31) apparently because they have not decided whether any waste (likely filtered to remove suspended solids) would be sent to the HLW melters. At this time all TWCS wastes go only to the PT facility and there is some recycle of wastes from the PT facility back to TWCS for further treatment (refer to footnote \#6 on page 3.1 for discussion on the operations to be performed in the TWCS) to may be built in the future. 
Table 3-7. (continued)

\begin{tabular}{|c|c|c|c|c|c|c|c|c|}
\hline & Phase 1 & Phase 2 & Phase 3 & Phase 4a & Phase 4B & Phase 4C & $\begin{array}{c}\text { Vol } \\
\text { Weighted } \\
\text { Ave } \\
\end{array}$ & $\begin{array}{c}\text { Vol } \\
\text { Weighted } \\
\text { Ave } \\
\end{array}$ \\
\hline Interface $^{*}$ & $35 a$ & $35 a$ & $35 a$ & $35 a$ & $35 a$ & $35 a$ & $\mathrm{mg} / \mathrm{L}$ & M \\
\hline $\begin{array}{c}\text { Chemical } \\
\text { Components } \\
(\mathrm{mg} / \mathrm{L})\end{array}$ & none & none & & & & & & \\
\hline Aluminum & & & $8.96 \mathrm{E}+03$ & $4.60 \mathrm{E}+04$ & $4.60 \mathrm{E}+04$ & $3.07 E+04$ & $4.13 \mathrm{E}+04$ & $1.53 \mathrm{E}+00$ \\
\hline Bismuth & & & $1.34 \mathrm{E}+03$ & $3.32 E+03$ & $7.86 \mathrm{E}+03$ & $4.21 \mathrm{E}+03$ & $5.29 \mathrm{E}+03$ & 2.53E-02 \\
\hline Chlorine & & & $1.12 \mathrm{E}+01$ & $3.45 \mathrm{E}+00$ & $1.94 \mathrm{E}+00$ & $2.15 \mathrm{E}+00$ & $3.02 \mathrm{E}+00$ & $8.50 \mathrm{E}-05$ \\
\hline Chromium & & & $6.86 \mathrm{E}+02$ & $1.16 \mathrm{E}+03$ & $6.42 \mathrm{E}+02$ & $1.58 \mathrm{E}+03$ & $9.88 \mathrm{E}+02$ & $1.90 \mathrm{E}-02$ \\
\hline Fluorine & & & $2.18 \mathrm{E}+02$ & $8.12 \mathrm{E}+00$ & $4.21 \mathrm{E}+01$ & $1.76 \mathrm{E}+03$ & $3.39 \mathrm{E}+02$ & $1.78 \mathrm{E}-02$ \\
\hline Iron & & & $5.35 \mathrm{E}+04$ & $1.43 E+04$ & $1.53 \mathrm{E}+04$ & $1.55 E+04$ & $1.71 \mathrm{E}+04$ & $3.06 \mathrm{E}-01$ \\
\hline Nickel & & & $3.06 \mathrm{E}+03$ & $2.10 \mathrm{E}+03$ & $2.00 \mathrm{E}+03$ & $1.05 \mathrm{E}+03$ & $1.93 \mathrm{E}+03$ & 3.28E-02 \\
\hline Nitrate & & & $3.49 \mathrm{E}+02$ & $1.89 \mathrm{E}+02$ & $1.50 \mathrm{E}+02$ & $1.97 \mathrm{E}+02$ & $1.83 \mathrm{E}+02$ & 2.95E-03 \\
\hline Nitrite & & & $1.12 \mathrm{E}+04$ & $1.12 \mathrm{E}+04$ & $8.03 E+03$ & $1.54 \mathrm{E}+04$ & $1.06 \mathrm{E}+04$ & $2.30 \mathrm{E}-01$ \\
\hline Potassium & & & $1.35 \mathrm{E}+02$ & $1.31 \mathrm{E}+02$ & $5.79 \mathrm{E}+01$ & $8.03 E+01$ & $9.15 \mathrm{E}+01$ & $2.34 \mathrm{E}-03$ \\
\hline Phosphate & & & $3.65 \mathrm{E}+01$ & $1.32 \mathrm{E}+01$ & $1.17 \mathrm{E}+02$ & $5.36 \mathrm{E}+01$ & $6.54 \mathrm{E}+01$ & 6.89E-04 \\
\hline Sodium & & & $7.83 \mathrm{E}+03$ & $6.87 \mathrm{E}+03$ & $5.31 \mathrm{E}+03$ & $1.07 \mathrm{E}+04$ & $6.93 \mathrm{E}+03$ & $3.01 \mathrm{E}-01$ \\
\hline Sulfate & & & $2.79 \mathrm{E}+01$ & $1.28 \mathrm{E}+01$ & $3.10 \mathrm{E}+01$ & $4.11 \mathrm{E}+02$ & $9.07 \mathrm{E}+01$ & 9.44E-04 \\
\hline TOC & & & $1.95 \mathrm{E}+01$ & $9.19 \mathrm{E}+00$ & $6.36 \mathrm{E}+00$ & $6.91 \mathrm{E}+00$ & $8.17 \mathrm{E}+00$ & 8.51E-05 \\
\hline Oxalate & & & $7.86 \mathrm{E}+02$ & $8.17 \mathrm{E}+02$ & $2.21 \mathrm{E}+02$ & $1.33 \mathrm{E}+03$ & $6.53 \mathrm{E}+02$ & $6.80 \mathrm{E}-03$ \\
\hline Zirconium & & & $1.63 \mathrm{E}+04$ & $4.96 \mathrm{E}+03$ & $8.84 \mathrm{E}+03$ & $2.25 E+03$ & $6.76 \mathrm{E}+03$ & 7.04E-02 \\
\hline $\begin{array}{c}\text { Radionuclides } \\
\text { (Ci/L) }\end{array}$ & none & none & & & & & & \\
\hline${ }^{99} \mathrm{Tc}$ & & & $4.71 \mathrm{E}-07$ & 1.18E-07 & $5.11 \mathrm{E}-08$ & $6.00 \mathrm{E}-08$ & Total Tc(Ci) & \\
\hline $\begin{array}{l}{ }^{99} \mathrm{Tc}(\mathrm{Ci}) \\
\text { Inventory }\end{array}$ & & & $1.57 \mathrm{E}+00$ & $2.47 \mathrm{E}+00$ & $1.30 \mathrm{E}+00$ & $6.29 \mathrm{E}-01$ & $5.98 \mathrm{E}+00$ & \\
\hline $\begin{array}{c}\text { Total Volume } \\
\text { (gal) }\end{array}$ & none & none & $8.83 E+05$ & $5.53 E+06$ & $6.73 E+06$ & $2.77 \mathrm{E}+06$ & Total Vol. (L) & \\
\hline $\begin{array}{c}\text { Total Volume } \\
\text { (L) }\end{array}$ & & & $3.34 \mathrm{E}+06$ & $2.09 \mathrm{E}+07$ & $2.55 \mathrm{E}+07$ & $1.05 \mathrm{E}+07$ & $6.02 \mathrm{E}+07$ & \\
\hline
\end{tabular}


Table 3-7. (continued)

\begin{tabular}{|c|c|c|c|c|c|c|c|c|}
\hline & Phase 1 & Phase 2 & Phase 3 & Phase 4a & Phase 4B & Phase 4C & $\begin{array}{c}\text { Vol } \\
\text { Weighted } \\
\text { Ave }\end{array}$ & $\begin{array}{c}\text { Vol } \\
\text { Weighted } \\
\text { Ave }\end{array}$ \\
\hline Interface $^{*}$ & 45 & 45 & 45 & 45 & 45 & 45 & $\mathrm{mg} / \mathrm{L}$ & M \\
\hline $\begin{array}{c}\text { Chemical } \\
\text { Components } \\
(\mathrm{mg} / \mathrm{L})\end{array}$ & none & none & none & & & & & \\
\hline Aluminum & & & & $1.71 \mathrm{E}+04$ & $1.24 \mathrm{E}+04$ & $1.00 \mathrm{E}+04$ & $1.32 \mathrm{E}+04$ & 4.90E-01 \\
\hline Bismuth & & & & $1.44 \mathrm{E}+02$ & $1.70 \mathrm{E}+02$ & $1.61 \mathrm{E}+02$ & $1.59 \mathrm{E}+02$ & $7.61 \mathrm{E}-04$ \\
\hline Chlorine & & & & $2.66 \mathrm{E}+03$ & $1.61 \mathrm{E}+03$ & $1.60 \mathrm{E}+03$ & $1.94 \mathrm{E}+03$ & $5.48 \mathrm{E}-02$ \\
\hline Chromium & & & & $1.60 \mathrm{E}+03$ & $1.11 \mathrm{E}+03$ & $8.36 \mathrm{E}+02$ & $1.19 \mathrm{E}+03$ & $2.29 \mathrm{E}-02$ \\
\hline Fluorine & & & & $1.98 \mathrm{E}+03$ & $5.09 \mathrm{E}+03$ & $5.51 \mathrm{E}+03$ & $4.21 \mathrm{E}+03$ & $2.22 \mathrm{E}-01$ \\
\hline Iron & & & & $1.75 \mathrm{E}+02$ & $1.64 \mathrm{E}+02$ & $1.14 \mathrm{E}+02$ & $1.53 \mathrm{E}+02$ & $2.74 \mathrm{E}-03$ \\
\hline Nickel & & & & $7.34 \mathrm{E}+00$ & $4.77 \mathrm{E}+00$ & $3.31 \mathrm{E}+00$ & $5.17 \mathrm{E}+00$ & $8.81 \mathrm{E}-05$ \\
\hline Nitrate & & & & $4.28 \mathrm{E}+04$ & $3.17 \mathrm{E}+04$ & $3.76 \mathrm{E}+04$ & $3.70 \mathrm{E}+04$ & 5.96E-01 \\
\hline Nitrite & & & & $1.05 \mathrm{E}+05$ & $1.28 \mathrm{E}+05$ & $1.56 \mathrm{E}+05$ & $1.29 \mathrm{E}+05$ & $2.80 \mathrm{E}+00$ \\
\hline Potassium & & & & $2.63 \mathrm{E}+03$ & $1.15 \mathrm{E}+03$ & $8.02 \mathrm{E}+02$ & $1.52 \mathrm{E}+03$ & $3.90 \mathrm{E}-02$ \\
\hline Phosphate & & & & $5.76 \mathrm{E}+03$ & $1.58 \mathrm{E}+04$ & $1.62 \mathrm{E}+04$ & $1.27 \mathrm{E}+04$ & 1.34E-01 \\
\hline Sodium & & & & $1.79 \mathrm{E}+05$ & $1.76 \mathrm{E}+05$ & $1.75 \mathrm{E}+05$ & $1.77 \mathrm{E}+05$ & $7.68 \mathrm{E}+00$ \\
\hline Sulfate & & & & $4.56 \mathrm{E}+03$ & $1.12 \mathrm{E}+04$ & $1.77 \mathrm{E}+04$ & $1.09 \mathrm{E}+04$ & $1.14 \mathrm{E}-01$ \\
\hline TOC & & & & $2.05 E+03$ & $1.38 \mathrm{E}+03$ & $1.59 \mathrm{E}+03$ & $1.66 \mathrm{E}+03$ & $1.72 \mathrm{E}-02$ \\
\hline Oxalate & & & & $2.76 \mathrm{E}+03$ & $3.59 \mathrm{E}+03$ & $4.90 \mathrm{E}+03$ & $3.70 \mathrm{E}+03$ & $3.86 \mathrm{E}-02$ \\
\hline \multicolumn{9}{|l|}{ Zirconium } \\
\hline $\begin{array}{c}\text { Radionuclides } \\
(\mathrm{Ci} / \mathrm{L})\end{array}$ & none & none & none & & & & & \\
\hline${ }^{99} \mathrm{Tc}$ & & & & 9.95E-05 & 4.69E-05 & 5.10E-05 & Total Tc(Ci) & \\
\hline $\begin{array}{l}{ }^{99} \mathrm{Tc}(\mathrm{Ci}) \\
\text { Inventory }\end{array}$ & & & & $6.25 \mathrm{E}+03$ & $3.59 \mathrm{E}+03$ & $2.88 \mathrm{E}+03$ & $1.27 \mathrm{E}+04$ & \\
\hline $\begin{array}{c}\begin{array}{c}\text { Total Volume } \\
\text { (gal) }\end{array} \\
\end{array}$ & & & & $1.66 \mathrm{E}+07$ & $2.02 \mathrm{E}+07$ & $1.49 \mathrm{E}+07$ & Total Vol. (L) & \\
\hline $\begin{array}{c}\text { Total Volume } \\
\text { (L) }\end{array}$ & & & & $6.28 \mathrm{E}+07$ & $7.65 \mathrm{E}+07$ & $5.64 \mathrm{E}+07$ & $1.96 \mathrm{E}+08$ & \\
\hline
\end{tabular}


Table 3-7. (continued)

\begin{tabular}{|c|c|c|c|c|c|c|c|c|}
\hline & Phase 1 & Phase 2 & Phase 3 & Phase 4a & Phase 4B & Phase 4C & $\begin{array}{c}\text { Vol } \\
\text { Weighted } \\
\text { Ave } \\
\end{array}$ & $\begin{array}{c}\text { Vol } \\
\text { Weighted } \\
\text { Ave } \\
\end{array}$ \\
\hline Interface $^{*}$ & 46 & 46 & 46 & 46 & 46 & 46 & $\mathrm{mg} / \mathrm{L}$ & M \\
\hline $\begin{array}{c}\text { Chemical } \\
\text { Components } \\
(\mathrm{mg} / \mathrm{L})\end{array}$ & none & none & none & & & none & & \\
\hline Aluminum & & & & $3.71 \mathrm{E}+03$ & $1.88 \mathrm{E}+03$ & & $3.58 \mathrm{E}+03$ & 1.32E-01 \\
\hline Bismuth & & & & $6.26 \mathrm{E}+01$ & $9.08 \mathrm{E}+01$ & & $6.47 \mathrm{E}+01$ & $2.40 \mathrm{E}-03$ \\
\hline Chlorine & & & & $2.10 \mathrm{E}+03$ & $1.80 \mathrm{E}+03$ & & $2.08 \mathrm{E}+03$ & 7.70E-02 \\
\hline Chromium & & & & $6.23 \mathrm{E}+02$ & $6.83 \mathrm{E}+02$ & & $6.27 \mathrm{E}+02$ & 2.32E-02 \\
\hline Fluorine & & & & $5.14 \mathrm{E}+02$ & $2.48 \mathrm{E}+03$ & & $6.58 \mathrm{E}+02$ & $2.44 \mathrm{E}-02$ \\
\hline Iron & & & & $6.38 \mathrm{E}+01$ & $6.18 \mathrm{E}+01$ & & $6.37 \mathrm{E}+01$ & $2.36 \mathrm{E}-03$ \\
\hline Nickel & & & & $1.28 \mathrm{E}+00$ & $1.06 \mathrm{E}-01$ & & $1.19 \mathrm{E}+00$ & $4.42 \mathrm{E}-05$ \\
\hline Nitrate & & & & $4.54 \mathrm{E}+04$ & $2.89 \mathrm{E}+04$ & & $4.42 \mathrm{E}+04$ & $1.64 \mathrm{E}+00$ \\
\hline Nitrite & & & & $1.22 \mathrm{E}+05$ & $1.11 \mathrm{E}+05$ & & $1.21 \mathrm{E}+05$ & $4.49 \mathrm{E}+00$ \\
\hline Potassium & & & & $3.02 \mathrm{E}+03$ & $2.11 \mathrm{E}+03$ & & $2.95 \mathrm{E}+03$ & $1.09 \mathrm{E}-01$ \\
\hline Phosphate & & & & $3.30 \mathrm{E}+03$ & $3.70 \mathrm{E}+03$ & & $3.33 \mathrm{E}+03$ & 1.23E-01 \\
\hline Sodium & & & & $1.25 \mathrm{E}+05$ & $1.02 \mathrm{E}+05$ & & $1.23 \mathrm{E}+05$ & $4.57 \mathrm{E}+00$ \\
\hline Sulfate & & & & $3.01 \mathrm{E}+03$ & $3.96 \mathrm{E}+03$ & & $3.08 \mathrm{E}+03$ & $1.14 \mathrm{E}-01$ \\
\hline TOC & & & & $3.87 \mathrm{E}+03$ & $1.64 \mathrm{E}+03$ & & $3.71 \mathrm{E}+03$ & $1.37 \mathrm{E}-01$ \\
\hline Oxalate & & & & $9.07 \mathrm{E}+02$ & $1.32 \mathrm{E}+03$ & & $9.37 \mathrm{E}+02$ & $3.47 \mathrm{E}-02$ \\
\hline \multicolumn{9}{|l|}{ Zirconium } \\
\hline $\begin{array}{c}\text { Radionuclides } \\
(\mathrm{Ci} / \mathrm{L})\end{array}$ & none & none & none & & & none & & \\
\hline${ }^{99} \mathrm{Tc}$ & & & & 6.76E-05 & 4.27E-05 & & Total Tc(Ci) & \\
\hline $\begin{array}{l}{ }^{99} \mathrm{Tc}(\mathrm{Ci}) \\
\text { Inventory }\end{array}$ & & & & $2.50 \mathrm{E}+03$ & $1.25 \mathrm{E}+02$ & & $2.62 \mathrm{E}+03$ & \\
\hline $\begin{array}{c}\text { Total Volume } \\
\text { (gal) }\end{array}$ & none & none & none & $9.73 E+06$ & $7.74 \mathrm{E}+05$ & none & Total Vol. (L) & \\
\hline $\begin{array}{c}\text { Total Volume } \\
\text { (L) }\end{array}$ & & & & $3.69 \mathrm{E}+07$ & $2.93 \mathrm{E}+06$ & & $3.99 \mathrm{E}+07$ & \\
\hline
\end{tabular}

${ }^{(*)}$ See Table 3-6 for definition of interfaces.

(a) none = no waste stream was generated during this WTP mission phase.

(b) $\mathrm{NR}=$ not reported and assumed to be insignificant. 
Table 3-8. Treated Tank Waste Na Composition (in M) as a Function of Phase (Time)

\begin{tabular}{|l|c|c|c|c|c|c|}
\hline Waste goes (from $\rightarrow$ to) & Phase 1 & Phase 2 & Phase 3 & Phase 4a & Phase 4B & Phase 4C \\
\hline $\begin{array}{l}\text { 28 (LAWPS waste to } \\
\text { LAW melter) }\end{array}$ & none & 5.61 & none & none & none & none \\
\hline $\begin{array}{l}\text { 41a (PT waste to LAW } \\
\text { Melter }\end{array}$ & none & none & 7.96 & 7.91 & 7.78 & 7.70 \\
\hline $\begin{array}{l}\text { 31 (TWCS waste to } \\
\text { HLW melter) }\end{array}$ & No Data & No Data & No Data & No Data & No Data & No Data \\
\hline $\begin{array}{l}\text { 35a (PT waste to HLW } \\
\text { melter) }\end{array}$ & none & none & 0.34 & 0.30 & 0.23 & 0.47 \\
\hline $\begin{array}{l}\text { 45 (PT waste to SLAW } \\
\text { melter) }\end{array}$ & none & none & none & 7.78 & 7.65 & 7.68 \\
\hline $\begin{array}{l}\text { 46 (LAWPS waste to } \\
\text { SLAW melter) }\end{array}$ & none & none & none & 5.43 & 4.43 & none \\
\hline
\end{tabular}

Highlighted cells indicate that the Na concentration in this particular waste stream is likely too low to effectively remove the pertechnetate from treated tank wastes at the front end of the HLW melters.

As shown in Table 3-9, the interface 35 (treated waste from PT to the HLW waste melter) has so little

${ }^{99} \mathrm{Tc}$ in that its removal is likely not warranted, especially by use of SuperLig 639 because the Na concentration in this waste stream is much too low. It seems reasonable that the volumes of tank waste transferred into the various "pretreatment" facilities $\left(5.47 \times 10^{+8}\right.$ liters; see Table $\left.3-5\right)$ are essentially the same as the volume sent to the melters $\left(5.48 \times 10^{+8}\right.$ liters; see Table 3-9). However it is not clear why Table 3-5 shows the Tc inventory in this waste at 27,800 curies but the Tc inventory sent from these "pretreatment" facilities to the melters is estimated to be 37,100 curies. One explanation is that there is recycle of Tc into the PT facility from "off-gas" captured solutions that is then sent back through the LAW melters and perhaps later the SLAW melters. As mentioned earlier the total inventory of ${ }^{99} \mathrm{Tc}$ in the Hanford tanks is estimated at 26,500 Ci (Serne et al. 2014). Thus approximately 10,600 Ci (or 40\%) gets recycled through the PT and back to LAW/SLAW melters until it is retained in the ILAW glass. A similar mass balance for volume and Tc inventory into LAWPS (interface 27a) and out of LAWPS (interfaces 28 plus 46) is shown in Table 3-10. Similarly the mass balance for volume and Tc inventory into PT and out of the PT will be covered in Section 5, where the focus is on off-gas captured secondary liquid wastes. The mass balance for the LAWPS facility used solely during the direct feed campaign (Phase 2) is good. Volumes of waste and total Tc inventory entering and leaving LAWPS are essentially the same.

Table 3-9. Overall Volume and Tc Inventory (Ci) Transferred From "Pre-treatment” to Melters

\begin{tabular}{|l|c|c|c|c|c|}
\hline \multicolumn{7}{|c|}{ From Pretreatment Facilities to Melters } \\
\hline Into: & Interface & vol (gal) & vol $(\mathbf{L})$ & Tc $(\mathbf{C i} / \mathbf{L})$ & Tc $(\mathbf{C i})$ \\
\hline LAW Melters & 28 & $1.95 \mathrm{E}+07$ & $7.38 \mathrm{E}+07$ & $9.39 \mathrm{E}-05$ & $6.93 \mathrm{E}+03$ \\
\hline LAW Melters & $41 \mathrm{a}$ & $4.69 \mathrm{E}+07$ & $1.78 \mathrm{E}+08$ & variable & $1.48 \mathrm{E}+04$ \\
\hline HLW Melters & $35 \mathrm{a}$ & $1.59 \mathrm{E}+07$ & $6.02 \mathrm{E}+07$ & variable & $5.98 \mathrm{E}+00$ \\
\hline SLAW Melters & 45 & $5.17 \mathrm{E}+07$ & $1.96 \mathrm{E}+08$ & variable & $1.27 \mathrm{E}+04$ \\
\hline SLAW Melters & 46 & $1.05 \mathrm{E}+07$ & $3.99 \mathrm{E}+07$ & variable & $2.62 \mathrm{E}+03$ \\
\hline & Totals & $\mathbf{1 . 4 5 E}+\mathbf{0 8}$ & $\mathbf{5 . 4 8 E + 0 8}$ & variable & $\mathbf{3 . 7 1 E + 0 4}$ \\
\hline
\end{tabular}


Table 3-10. Overall Volume and Tc Inventory (Ci) Mass Balance for LAWPS

\begin{tabular}{|l|c|c|c|}
\hline Facility & Interfaces & $\begin{array}{c}\text { Total Volume } \\
(\mathrm{L})\end{array}$ & Total Tc (Ci) \\
\hline LAWPS (in) & $27 \mathrm{a}$ & $1.14 \mathrm{E}+08$ & $9.53 \mathrm{E}+03$ \\
\hline LAWPS (out) & $28+46$ & $1.14 \mathrm{E}+08$ & $9.55 \mathrm{E}+03$ \\
\hline $\begin{array}{l}\text { Mass Balance (Out-In)/In } \\
\%\end{array}$ & $-0.3 \%$ & $0.3 \%$ \\
\hline $\begin{array}{l}\text { Note: when using only 3 significant figures for the volume in this Table the } \\
\text { slight difference in volumes entering and leaving LAWPS are masked. }\end{array}$ \\
\hline
\end{tabular}

Removal of ${ }^{99}$ Tc after leaving the "pre-treatment" facilities [LAWPS, TWCS, and PT] at the front end of the LAW and SLAW melters likely is not practical using SuperLig 639 because of resin high costs, potentially non-optimum waste stream $\mathrm{Na}$ concentrations, and the need to build a Tc removal unit at the melters. Section 5 discusses locations in the over-all One System flowsheet where ${ }^{99}$ Tc removal is more effective. 


\subsection{Composition and Volume of SuperLig 639 Eluate}

SuperLig 639 is a resin of the SuperLigand family that is manufactured by IBC Advanced Technologies (American Fork, UT) (SuperLig (2015)). SuperLigands are based on a Molecular Recognition Technology that uses molecular recognition to achieve high selectivity for particular species of interest. The application of SuperLig 639 for pertechnetate removal is based on ion pair extraction in which the $\mathrm{Na}^{+}$ion is complexed by a macro-cyclic ligand and the pertechnetate ion preferentially accompanies the Na as the counter anion. The efficiency of this separation process thus is highly dependent on the $\mathrm{Na}^{+}$concentration and, while it is high for liquid wastes such as LAW, it is ineffective for low sodium concentration waste streams. The selectivity for $\mathrm{TcO}_{4}{ }^{-}$is driven by its preference to the lipophilic substrates due to the relatively low hydration energy of this large charge-diffuse anion. Pertechnetate is a minor component of LAW and is present at micro- to low millimolar concentrations and is unable to fully balance the charge of all $\mathrm{Na}^{+}$ions bound by SuperLig 639. The primary anion competitor is nitrate, however other anions such as nitrite, etc. are also retained in the SuperLig 639 as counter ions to the $\mathrm{Na}^{+}$. See Hamm et al. (2013) and Rapko et al. (2003) for more discussion on competing anions.

As noted above in Section 3.0, there is a loss of affinity in SuperLig 639 for sodium pertechnetate at low sodium concentrations. This behavior allows the elution and regeneration of the SuperLig 639 resin to be achieved with water, preferably at elevated temperature $\left(65^{\circ} \mathrm{C}\right)$.

The resulting eluate has been demonstrated to have a rather complex composition (Burgeson et al. 2005). Only a handful of actual tank LAW feeds have been processed with SuperLig 639 for Tc removal, and Table 4-1 summarizes composition of the resulting eluates. The SuperLig 639 eluate is composed of sodium, potassium, and various anions: nitrate, chromate, aluminate, hydroxide, and carbonate. This confirms that the SuperLig 639 does not act as ion exchanger, but rather retains sodium or potassium ion pairs with various anions.

One example of the performance of water regeneration of a small-scale SuperLig 639 packed column that was loaded with DST supernate from Tank AZ-101 is found in Burgeson et al. (2004b). The peak ${ }^{99} \mathrm{Tc}^{10}$ concentration of the water eluate was 81 times the ${ }^{99} \mathrm{Tc}$ concentration in the DST feed and was found in the second bed volume of eluate; the ${ }^{99}$ Tc concentration in the eluate dropped slightly after this and then leveled out until the 8th bed volume of eluate. At this point, the ${ }^{99}$ Tc concentration dropped quickly. A total of 17 bed volumes of water eluate were required before the ${ }^{99}$ Tc concentration dropped below $1 \%$ of the concentration in the DST supernate feed. Overall, after rinsing the Tc loaded SuperLig 639 column with 17 bed volumes of water, the ${ }^{99}$ Tc concentration of the composited regenerant was 4578 $\mu \mathrm{Ci} / \mathrm{L}$, which correlates to a $C / C_{0}$ of 12.2 . Assuming that between 22,000 and 30,000 liters of SuperLig 639 resin recycled 50 times can treat the entire 550 million liters of DST supernatant (see Section 2 above) and 17 bed volumes are needed to elute Tc, the total volume of Tc eluate will be between 18.7 and 25.5 million liters (or 4.94-6.74 $\times 10^{6}$ gallons). Therefore further concentration and purification of this Tc eluate may be required for the stabilization in a Tc-specific waste form as described later in this report.

\footnotetext{
${ }^{10}$ Notation ${ }^{99} \mathrm{Tc}$ is used here to differentiate between Tc isotopes ${ }^{99} \mathrm{Tc}$ and ${ }^{99 \mathrm{~m}} \mathrm{Tc}$ used by Burgeson et al. (2004b). The source of ${ }^{99} \mathrm{Tc}$ is actual tank waste while ${ }^{99 \mathrm{~m}} \mathrm{Tc}$ was added to monitor experimental Tc recovery.
} 
It is important to note that these LAW feeds that were processed using SuperLig 639 were first subjected to ${ }^{137} \mathrm{Cs}$ removal using SuperLig 644 resin prior to Tc separation. In the currently proposed baseline LAW pretreatment scheme, ${ }^{137} \mathrm{Cs}$ separation will be achieved using spherical resorcinol formaldehyde (SRF) resin (Nash et al. 2006). Therefore the LAW feed subjected to the ${ }^{137} \mathrm{Cs}$ removal by SuperLig 644 and SRF likely have somewhat different compositions, specifically with regard to Tc concentration. The SuperLig 644 technology utilizes a macro-cyclic ligand for ${ }^{137} \mathrm{Cs}$ removal, and therefore may be susceptible to ion pair extractions and so retains some quantity of Tc (Kurath and Wagner 2000). SRF is a weak acid resin, uptakes $\mathrm{Cs}^{+}$by proton exchange (Nash et al. 2006), and has no affinity for the $\mathrm{TcO}_{4}{ }^{-}$anion. To date no testing has been done for Tc removal by SuperLig 639 after using SRF to remove ${ }^{137} \mathrm{Cs}$ from LAW.

Table 4-1. Main Components of the SuperLig 639 Eluate Reported for Processing the Actual Tank Wastes

\begin{tabular}{|l|c|c|c|c|c|}
\hline \multirow{2}{*}{$\begin{array}{l}\text { SuperLig } 639 \\
\text { Eluate } \\
\text { Component }\end{array}$} & \multicolumn{5}{|c|}{ Component Concentration (mol/L) for Tank Waste } \\
\cline { 2 - 6 } & $241-\mathrm{AP} 101^{\text {a) }}$ & $241-\mathrm{AN} 102-C 104^{\text {a }}$ & $241-\mathrm{AP} 104^{\text {a) }}$ & $241-\mathrm{AZ101}{ }^{\text {a) }}$ & $241-\mathrm{AZ102}{ }^{\mathrm{b})}$ \\
\hline Tc & $2.70 \mathrm{E}-04$ & $1.07 \mathrm{E}-04$ & $5.68 \mathrm{E}-04$ & $2.38 \mathrm{E}-03$ & $3.53 \mathrm{E}-04$ \\
\hline $\mathrm{Na}$ & $1.54 \mathrm{E}-02$ & $1.22 \mathrm{E}-02$ & $1.20 \mathrm{E}-02$ & $9.50 \mathrm{E}-03$ & $1.54 \mathrm{E}-02$ \\
\hline $\mathrm{K}$ & $1.30 \mathrm{E}-03$ & $1.30 \mathrm{E}-03$ & $1.30 \mathrm{E}-03$ & $1.10 \mathrm{E}-03$ & $2.06 \mathrm{E}-03$ \\
\hline $\mathrm{Ca}$ & NR & $1.50 \mathrm{E}-04$ & NR & BD & $3.03 \mathrm{E}-05$ \\
\hline $\mathrm{Al}$ & $5.19 \mathrm{E}-04$ & $3.60 \mathrm{E}-04$ & $1.85 \mathrm{E}-04$ & $4.40 \mathrm{E}-05$ & $1.31 \mathrm{E}-03$ \\
\hline Cl & $6.21 \mathrm{E}-05$ & $8.50 \mathrm{E}-05$ & $1.40 \mathrm{E}-04$ & $1.60 \mathrm{E}-05$ & $9.69 \mathrm{E}-03$ \\
\hline F & NR & $5.80 \mathrm{E}-04$ & $1.70 \mathrm{E}-04$ & $1.00 \mathrm{E}-04$ & BD \\
\hline Carbonate & $2.70 \mathrm{E}-03$ & $9.20 \mathrm{E}-03$ & $4.00 \mathrm{E}-03$ & $2.00 \mathrm{E}-03$ & NR \\
\hline Chromate & $2.69 \mathrm{E}-03$ & $9.60 \mathrm{E}-06$ & $9.60 \mathrm{E}-06$ & $9.80 \mathrm{E}-06$ & $2.98 \mathrm{E}-04$ \\
\hline Nitrite & $6.74 \mathrm{E}-04$ & $1.10 \mathrm{E}-03$ & $6.50 \mathrm{E}-04$ & $9.60 \mathrm{E}-04$ & $1.26 \mathrm{E}-02$ \\
\hline Nitrate & $1.65 \mathrm{E}-03$ & $2.10 \mathrm{E}-03$ & $9.90 \mathrm{E}-04$ & $6.90 \mathrm{E}-04$ & $1.13 \mathrm{E}-02$ \\
\hline Hydroxide & $4.60 \mathrm{E}-03$ & $1.00 \mathrm{E}-02$ & $5.00 \mathrm{E}-03$ & $3.00 \mathrm{E}-03$ & $5.20 \mathrm{E}-02$ \\
\hline Phosphate & $1.50 \mathrm{E}-05$ & $2.60 \mathrm{E}-06$ & $1.40 \mathrm{E}-05$ & $1.50 \mathrm{E}-05$ & $1.61 \mathrm{E}-04$ \\
\hline Sulfate & $5.31 \mathrm{E}-05$ & $9.40 \mathrm{E}-05$ & $7.40 \mathrm{E}-05$ & $1.30 \mathrm{E}-04$ & $6.22 \mathrm{E}-03$ \\
\hline Oxalate & $1.59 \mathrm{E}-05$ & $2.30 \mathrm{E}-05$ & $6.80 \mathrm{E}-06$ & $1.10 \mathrm{E}-05$ & $2.43 \mathrm{E}-03$ \\
\hline U & $6.79 \mathrm{E}-03$ & $7.50 \mathrm{E}-09$ & $4.10 \mathrm{E}-09$ & NR & NR \\
\hline Total moles/L & $3.67 \mathrm{E}-02$ & $3.73 \mathrm{E}-02$ & $2.51 \mathrm{E}-02$ & $2.00 \mathrm{E}-02$ & $1.98 \mathrm{E}-01$ \\
\hline
\end{tabular}

Data are taken from Burgeson et al. (2005).

Data are taken from King and Calloway (2000).

NR $=$ not reported.

$\mathrm{BD}=$ below detection.

The SuperLig 639 eluate can potentially be used without further purification /pre-concentration to generate $\mathrm{Fe}$-Tc oxide waste form (see comparable waste simulant concentrations from which $\mathrm{TcO}_{4}{ }^{-}$was successfully removed in Um et al. (2010)), but it cannot be used directly to fabricate the metal alloy or the sodalite waste form because of the high concentrations of sodium and other anions, respectively, as well as the low concentration of $\mathrm{TcO}_{4}{ }^{-}$. For this reason, if these immobilization technologies were used, further separation processes would be needed, making SuperLig 639 a less desirable option for separating Tc from LAW. 


\subsection{Compositions and Volumes of Off-gas Condensate/Flush Waters}

Similar to the tables created in Section 3.0 for the tank wastes that could have Tc removed from LAW prior to being sent to melters, in this section we generate tables containing the volumes of secondary liquid wastes, chemical compositions, and Tc concentrations in secondary liquid wastes for the four defined operational phases of WTP. Our interest is constructing a summary of the overall WTP mission interfaces that constitute liquid waste streams that currently would be sent back to DSTs (prior to completion of the WTP PT) and afterwards to the PT. The HTWOS estimates, documented in an Excel file “RPP Reference Integrated Flowsheet Mass Flow Calculations” dated 08/03/2015, were used for volumes of liquid waste and chemical and Tc concentrations. In this section we focus on removing ${ }^{99} \mathrm{Tc}$ from waste streams captured in off-gas systems downstream from the melters (LAW, and HLW) ${ }^{11}$, although it will be shown that off-gas from the HLW melters do not contain large enough quantities of ${ }^{99}$ Tc to warrant removal. During DFLAW the only facility that receives captured off-gas wastes is the EMF. ${ }^{12}$ Later the PT facility will receive melter off-gas wastes and currently the presumed supplemental melters (SLAW) will internally recycle captured off-gas wastes directly back to the SLAW melters with a dilute secondary waste stream sent to the LERF/ETF facility. The overall detailed flow chart in Figure 3-1 contains 85 interfaces (shown as diamonds) between the various facilities. These 85 interfaces are defined in Arm et al. (2014) in their Table 2-1. Recall that the locations of interfaces in our Table 5-1 and Table 5-2 are identified by the numbered diamonds in Figure 3-1. We keep the numbering system the same as used by Arm et al. (2014).

Table 5-1 shows liquid waste streams that enter the EMF, including those that captured volatile constituents, including Tc, during the DFLAW phase (Phase 2) that are recycled back from the LAW melters (interface 84a). Waste streams that exit the EMF include waste sent back to DSTs (interface 29), wastes recycled to the LAW melters (interface 84b) and dilute wastes sent to LERF/ETF (interface 83) and off-gas vented out stacks (interface 81). The latter two have insignificant quantities of ${ }^{99} \mathrm{Tc}$ as shown in Table 5-2. Theoretically, Tc could be removed from waste streams (interfaces 29 and $84 \mathrm{~b}$ ) as they leave EMF or from interface 84a as it enters EMF.

The exact method for removing the off-gas captured ${ }^{99} \mathrm{Tc}$ and the location for performing the ${ }^{99} \mathrm{Tc}$ removal have not been established but later in this section some proposed locations are offered.

\footnotetext{
${ }^{11}$ The current One System WTP mass flow sheet assumes that the SLAW melter facility contains an evaporator in which off-gas captured volatile species are concentrated and recycled back to the SLAW melters without any transfer to another facility such as the PT facility.

12 The EMF is currently in the conceptual design phase. The main function of the EMF will be to concentrate secondary liquid effluent from the LAW off-gas treatment system during DFLAW operations. The overhead condensate stream will be transferred to the LERF/ETF facility. The "bottoms" or slurry concentrate stream will be partially recycled back to the LAW feed tank in the LAW Vitrification Facility. Any remaining slurry concentrate will be treated for corrosion control and returned to the DST system.
} 
Table 5-1. Interfaces where Liquid Wastes are Sent During DFLAW Operations

\begin{tabular}{|c|l|l|l|l|}
\hline Interface & Interface Name & From & To & Primary Flow \\
\hline 29 & EMF Bottoms Returns & WTP EMF & East Area DSTs & Secondary Liquid Waste \\
\hline $84 \mathrm{~b}$ & EMF Bottoms Recycle & EMF & LAW Melter & Secondary Liquid Waste \\
\hline 83 & EMF 2 $^{\text {nd }}$ Liquid Waste & EMF & LERF/ETF & Secondary Liquid Waste \\
\hline 81 & Off-gas & EMF & Stack & Off-gas \\
\hline $84 a$ & EMF & LAW Melter & EMF & Secondary Liquid Waste \\
\hline
\end{tabular}

Table 5-2. Volumes, Tc Concentrations and Inventory, and Chemical Concentrations of Off-gas Secondary Liquid Waste Concentrated in EMF Before Being Recycled to LAW Melter or Returned to DSTs During DFLAW

\begin{tabular}{|c|c|c|c|c|c|c|c|c|}
\hline Phase: & 1 & 2 & 3 & $4 \mathbf{a}$ & 4B & $4 \mathrm{C}$ & \multirow{2}{*}{$\begin{array}{c}\text { Vol } \\
\text { Weighted } \\
\text { Ave } \\
\end{array}$} & \multirow{2}{*}{$\begin{array}{c}\text { Vol } \\
\text { Weighted } \\
\text { Ave } \\
\end{array}$} \\
\hline Interface $^{*}$ & 29 & 29 & 29 & 29 & 29 & 29 & & \\
\hline $\begin{array}{l}\text { Chemical } \\
\text { Comp. (mg/L) }\end{array}$ & none & & none & none & none & none & $\mathrm{mg} / \mathrm{L}$ & M \\
\hline Aluminum & & $6.08 \mathrm{E}+00$ & & & & & $6.08 \mathrm{E}+00$ & $2.25 \mathrm{E}-04$ \\
\hline Bismuth & & $3.78 \mathrm{E}-01$ & & & & & $3.78 \mathrm{E}-01$ & $1.81 \mathrm{E}-06$ \\
\hline Chlorine & & $1.28 \mathrm{E}+03$ & & & & & $1.28 \mathrm{E}+03$ & $3.61 \mathrm{E}-02$ \\
\hline Chromium & & $2.32 \mathrm{E}+01$ & & & & & $2.32 \mathrm{E}+01$ & 4.46E-04 \\
\hline Fluorine & & $2.57 \mathrm{E}+02$ & & & & & $2.57 \mathrm{E}+02$ & $1.35 \mathrm{E}-02$ \\
\hline Iron & & $7.08 \mathrm{E}-02$ & & & & & $7.08 \mathrm{E}-02$ & $1.27 \mathrm{E}-06$ \\
\hline Nickel & & $1.14 \mathrm{E}-02$ & & & & & $1.14 \mathrm{E}-02$ & $1.94 \mathrm{E}-07$ \\
\hline Nitrate & & $2.19 \mathrm{E}+05$ & & & & & $2.19 \mathrm{E}+05$ & $3.53 \mathrm{E}+00$ \\
\hline Nitrite & & $4.12 \mathrm{E}+03$ & & & & & $4.12 \mathrm{E}+03$ & 8.96E-02 \\
\hline Potassium & & $1.42 \mathrm{E}+02$ & & & & & $1.42 \mathrm{E}+02$ & 3.63E-03 \\
\hline Phosphate & & $2.90 \mathrm{E}+01$ & & & & & $2.90 \mathrm{E}+01$ & 3.05E-04 \\
\hline Sodium & & $1.13 \mathrm{E}+05$ & & & & & $1.13 \mathrm{E}+05$ & $4.91 \mathrm{E}+00$ \\
\hline Sulfate & & $1.04 \mathrm{E}+03$ & & & & & $1.04 \mathrm{E}+03$ & $1.08 \mathrm{E}-02$ \\
\hline TOC & & NR & & & & & NR & NR \\
\hline Oxalate & & NR & & & & & NR & NR \\
\hline Zirconium & & NR & & & & & NR & NR \\
\hline $\begin{array}{l}\text { Radionuclides } \\
\text { (Ci/L) }\end{array}$ & none & & none & none & none & none & & \\
\hline${ }^{99} \mathrm{Tc}$ & & $9.71 \mathrm{E}-05$ & & & & & $\begin{array}{c}\text { Total Tc } \\
\text { (Ci) }\end{array}$ & \\
\hline $\begin{array}{l}{ }^{99} \mathrm{Tc}(\mathrm{Ci}) \\
\text { Inventory }\end{array}$ & & $1.35 \mathrm{E}+03$ & & & & & $1.35 E+03$ & \\
\hline Total Vol. (gal) & none & $3.67 \mathrm{E}+06$ & none & none & none & none & Total Vol. (L) & \\
\hline Total Vol. (L) & & $1.39 \mathrm{E}+07$ & & & & & $1.39 \mathrm{E}+07$ & \\
\hline
\end{tabular}


Table 5.2. (continued)

\begin{tabular}{|c|c|c|c|c|c|c|c|c|}
\hline Phase: & 1 & 2 & 3 & $4 a$ & $4 \mathrm{~b}$ & $4 c$ & \multirow{2}{*}{$\begin{array}{c}\text { Vol } \\
\text { Weighted } \\
\text { Ave } \\
\end{array}$} & \multirow{2}{*}{$\begin{array}{c}\text { Vol } \\
\text { Weighted } \\
\text { Ave } \\
\end{array}$} \\
\hline Interface $^{*}$ & $84 \mathrm{~b}$ & $84 \mathrm{~b}$ & $84 \mathrm{~b}$ & $84 \mathrm{~b}$ & $84 \mathrm{~b}$ & $84 \mathrm{~b}$ & & \\
\hline $\begin{array}{l}\text { Chemical } \\
\text { Components } \\
\text { (mg/L) }\end{array}$ & none & & none & none & none & none & $\mathrm{mg} / \mathrm{L}$ & M \\
\hline Aluminum & & $8.19 \mathrm{E}+01$ & & & & & $8.19 \mathrm{E}+01$ & 3.03E-03 \\
\hline Bismuth & & $5.09 \mathrm{E}+00$ & & & & & $5.09 \mathrm{E}+00$ & $2.44 \mathrm{E}-05$ \\
\hline Chlorine & & $1.73 \mathrm{E}+04$ & & & & & $1.73 \mathrm{E}+04$ & 4.88E-01 \\
\hline Chromium & & $3.13 \mathrm{E}+02$ & & & & & $3.13 E+02$ & $6.02 \mathrm{E}-03$ \\
\hline Fluorine & & $3.47 \mathrm{E}+03$ & & & & & $3.47 \mathrm{E}+03$ & 1.83E-01 \\
\hline Iron & & $9.57 \mathrm{E}-01$ & & & & & $9.57 \mathrm{E}-01$ & $1.71 \mathrm{E}-05$ \\
\hline Nickel & & $1.54 \mathrm{E}-01$ & & & & & $1.54 \mathrm{E}-01$ & 2.62E-06 \\
\hline Nitrate & & $7.61 \mathrm{E}+02$ & & & & & $7.61 \mathrm{E}+02$ & $1.23 \mathrm{E}-02$ \\
\hline Nitrite & & $5.58 \mathrm{E}+04$ & & & & & $5.58 \mathrm{E}+04$ & $1.21 \mathrm{E}+00$ \\
\hline Potassium & & $1.91 \mathrm{E}+03$ & & & & & $1.91 \mathrm{E}+03$ & $4.88 \mathrm{E}-02$ \\
\hline Phosphate & & $3.92 \mathrm{E}+02$ & & & & & $3.92 \mathrm{E}+02$ & 4.13E-03 \\
\hline Sodium & & $4.41 \mathrm{E}+04$ & & & & & $4.41 \mathrm{E}+04$ & $1.92 \mathrm{E}+00$ \\
\hline Sulfate & & $1.40 \mathrm{E}+04$ & & & & & $1.40 \mathrm{E}+04$ & $1.46 \mathrm{E}-01$ \\
\hline TOC & & NR & & & & & NR & NR \\
\hline Oxalate & & NR & & & & & NR & NR \\
\hline Zirconium & & NR & & & & & NR & NR \\
\hline $\begin{array}{l}\text { Radionuclides } \\
\text { (Ci/L) }\end{array}$ & none & & none & none & none & none & & \\
\hline${ }^{99} \mathrm{Tc}$ & & $1.31 \mathrm{E}-03$ & & & & & $\begin{array}{c}\text { Total Tc } \\
\text { (Ci) }\end{array}$ & \\
\hline${ }^{99} \mathrm{Tc}$ (Ci) Inventory & & $7.69 \mathrm{E}+03$ & & & & & $7.69 \mathrm{E}+03$ & \\
\hline $\begin{array}{l}\text { Total Volume } \\
\text { (gal) }\end{array}$ & none & $1.55 E+06$ & none & none & none & none & $\begin{array}{c}\text { Total Volume } \\
\text { (L) }\end{array}$ & \\
\hline $\begin{array}{l}\text { Total Volume } \\
\text { (L) }\end{array}$ & & $5.87 \mathrm{E}+06$ & & & & & $5.87 \mathrm{E}+06$ & \\
\hline
\end{tabular}

- $\quad$ See Figure 3-1 for interface locations

none $=$ no waste stream was generated during this WTP mission phase.

$\mathrm{NR}=$ not reported and assumed to be insignificant 
Table 5-2. (continued)

\begin{tabular}{|c|c|c|c|c|c|c|c|c|}
\hline & $\begin{array}{c}\text { Phase } \\
1\end{array}$ & Phase 2 & $\begin{array}{c}\text { Phase } \\
3\end{array}$ & $\begin{array}{c}\text { Phase } \\
4 a\end{array}$ & $\begin{array}{c}\text { Phase } \\
4 \mathrm{~b}\end{array}$ & $\begin{array}{c}\text { Phase } \\
4 \mathrm{c}\end{array}$ & & \\
\hline Interface ${ }^{*}$ & 83 & 83 & 83 & 83 & 83 & 83 & $\begin{array}{c}\text { Vol } \\
\text { Weighted } \\
\text { Ave } \\
\end{array}$ & $\begin{array}{c}\text { Vol } \\
\text { Weighted } \\
\text { Ave } \\
\end{array}$ \\
\hline $\begin{array}{l}\text { Chemical } \\
\text { Components } \\
\text { (mg/L) }\end{array}$ & none & & none & none & none & none & $\mathrm{mg} / \mathrm{L}$ & $\mathrm{M}$ \\
\hline Aluminum & & 3.33E-06 & & & & & 3.33E-06 & $1.23 \mathrm{E}-10$ \\
\hline Bismuth & & $8.56 \mathrm{E}-03$ & & & & & $8.56 \mathrm{E}-03$ & $4.10 \mathrm{E}-08$ \\
\hline Chlorine & & $1.04 \mathrm{E}-01$ & & & & & $1.04 \mathrm{E}-01$ & 2.93E-06 \\
\hline Chromium & & 3.16E-04 & & & & & 3.16E-04 & 6.08E-09 \\
\hline Fluorine & & 2.36E-01 & & & & & 2.36E-01 & $1.24 \mathrm{E}-05$ \\
\hline Iron & & $1.60 \mathrm{E}-03$ & & & & & $1.60 \mathrm{E}-03$ & $2.86 \mathrm{E}-08$ \\
\hline Nickel & & 2.56E-04 & & & & & $2.56 \mathrm{E}-04$ & 4.36E-09 \\
\hline Nitrate & & $1.41 \mathrm{E}-05$ & & & & & $1.41 \mathrm{E}-05$ & 2.27E-10 \\
\hline Nitrite & & 1.73E-04 & & & & & 1.73E-04 & 3.76E-09 \\
\hline Potassium & & 2.15E-03 & & & & & $2.15 \mathrm{E}-03$ & $5.50 \mathrm{E}-08$ \\
\hline Phosphate & & 2.98E-04 & & & & & 2.98E-04 & 3.14E-09 \\
\hline Sodium & & 1.59E-02 & & & & & $1.59 \mathrm{E}-02$ & 6.91E-07 \\
\hline Sulfate & & $1.96 \mathrm{E}-01$ & & & & & $1.96 \mathrm{E}-01$ & $2.04 \mathrm{E}-06$ \\
\hline TOC & & NR & & & & & NR & NR \\
\hline Oxalate & & NR & & & & & NR & NR \\
\hline Zirconium & & NR & & & & & NR & NR \\
\hline $\begin{array}{l}\text { Radionuclide } \\
\text { s (Ci/L) }\end{array}$ & none & & none & none & none & none & $\begin{array}{c}\text { Total } \\
\text { Tc(Ci) }\end{array}$ & \\
\hline${ }^{99} \mathrm{Tc}$ & & $2.16 \mathrm{E}-10$ & & & & & & \\
\hline $\begin{array}{l}{ }^{99} \mathrm{Tc}(\mathrm{Ci}) \\
\text { Inventory }\end{array}$ & & 2.04E-02 & & & & & 2.04E-02 & \\
\hline $\begin{array}{l}\text { Total Volume } \\
\text { (gal) }\end{array}$ & none & $2.50 \mathrm{E}+07$ & none & none & none & none & & \\
\hline $\begin{array}{l}\text { Total Volume } \\
\text { (L) }\end{array}$ & & $9.46 \mathrm{E}+07$ & & & & & $9.46 \mathrm{E}+07$ & \\
\hline
\end{tabular}

- $\quad$ See Figure 3-1 for interface locations

none $=$ no waste stream was generated during this WTP mission phase.

$\mathrm{NR}=$ not reported and assumed to be insignificant. 
Table 5-2 (continued)

\begin{tabular}{|c|c|c|c|c|c|c|c|c|}
\hline & $\begin{array}{c}\text { Phase } \\
1\end{array}$ & $\begin{array}{c}\text { Phase } \\
2 \\
\end{array}$ & Phase 3 & $\begin{array}{c}\text { Phase } \\
4 a\end{array}$ & $\begin{array}{c}\text { Phase } \\
4 \mathrm{~b}\end{array}$ & $\begin{array}{c}\text { Phase } \\
4 \mathrm{c}\end{array}$ & & \\
\hline Interface $^{*}$ & 81 & 81 & & 81 & 81 & 81 & $\begin{array}{c}\text { Vol Weighted } \\
\text { Ave } \\
\end{array}$ & $\begin{array}{c}\text { Vol } \\
\text { Weighted } \\
\text { Ave } \\
\end{array}$ \\
\hline $\begin{array}{l}\text { Chemical } \\
\text { Components } \\
\text { (mg/L) }\end{array}$ & none & none & & none & none & none & $\mathrm{mg} / \mathrm{L}$ & M \\
\hline Aluminum & & & 7.12E-05 & & & & 7.12E-05 & 2.64E-09 \\
\hline Bismuth & & & 4.25E-03 & & & & 4.25E-03 & 2.03E-08 \\
\hline Chlorine & & & $1.88 \mathrm{E}-01$ & & & & $1.88 \mathrm{E}-01$ & $5.30 \mathrm{E}-06$ \\
\hline Chromium & & & 8.24E-04 & & & & 8.24E-04 & $1.58 \mathrm{E}-08$ \\
\hline Fluorine & & & $1.73 E+00$ & & & & $1.73 E+00$ & $9.11 \mathrm{E}-05$ \\
\hline Iron & & & 4.45E-02 & & & & 4.45E-02 & 7.97E-07 \\
\hline Nickel & & & 5.47E-03 & & & & 5.47E-03 & 9.32E-08 \\
\hline Nitrate & & & $1.88 \mathrm{E}-05$ & & & & $1.88 \mathrm{E}-05$ & 3.03E-10 \\
\hline Nitrite & & & 2.31E-04 & & & & $2.31 \mathrm{E}-04$ & $5.02 \mathrm{E}-09$ \\
\hline Potassium & & & 4.68E-02 & & & & 4.68E-02 & $1.20 \mathrm{E}-06$ \\
\hline Phosphate & & & 6.36E-03 & & & & 6.36E-03 & 6.69E-08 \\
\hline Sodium & & & 4.41E-01 & & & & 4.41E-01 & 1.92E-05 \\
\hline Sulfate & & & $6.47 \mathrm{E}-01$ & & & & $6.47 \mathrm{E}-01$ & $6.74 \mathrm{E}-06$ \\
\hline TOC & & & NR & & & & NR & NR \\
\hline Oxalate & & & NR & & & & NR & NR \\
\hline Zirconium & & & NR & & & & NR & NR \\
\hline $\begin{array}{l}\text { Radionuclid } \\
\text { es (Ci/L) }\end{array}$ & none & none & & none & none & none & & \\
\hline${ }^{99} \mathrm{Tc}$ & & & 4.62E-09 & & & & Total Tc (Ci) & \\
\hline $\begin{array}{l}{ }^{99} \mathrm{Tc}(\mathrm{Ci}) \\
\text { Inventory }\end{array}$ & & & 3.17E-05 & & & & 3.17E-05 & \\
\hline $\begin{array}{l}\text { Total } \\
\text { Volume (gal) }\end{array}$ & none & none & $1.81 \mathrm{E}+03$ & none & none & none & $\begin{array}{c}\text { Total Volume } \\
\text { (L) }\end{array}$ & \\
\hline $\begin{array}{l}\text { Total } \\
\text { Volume (L) }\end{array}$ & & & $6.85 E+03$ & & & & $6.85 E+03$ & \\
\hline
\end{tabular}

- See Figure 3-1 for interface locations

none $=$ no waste stream was generated during this WTP mission phase.

$\mathrm{NR}=$ not reported and assumed to be insignificant. 
Table 5-2. (continued)

\begin{tabular}{|c|c|c|c|c|c|c|c|c|}
\hline & $\begin{array}{c}\text { Phase } \\
1 \\
\end{array}$ & Phase 2 & $\begin{array}{c}\text { Phase } \\
3 \\
\end{array}$ & $\begin{array}{c}\text { Phase } \\
4 a\end{array}$ & $\begin{array}{c}\text { Phase } \\
\text { 4B }\end{array}$ & $\begin{array}{c}\text { Phase } \\
\text { 4C }\end{array}$ & & \\
\hline Interface $^{*}$ & $84 a$ & $84 a$ & $84 a$ & $84 a$ & $84 a$ & $84 a$ & $\begin{array}{c}\text { Vol } \\
\text { Weighted } \\
\text { Ave } \\
\end{array}$ & $\begin{array}{c}\text { Vol } \\
\text { Weighted } \\
\text { Ave } \\
\end{array}$ \\
\hline $\begin{array}{l}\text { Chemical } \\
\text { Components } \\
\text { (mg/L) }\end{array}$ & none & & none & none & none & none & $\mathrm{mg} / \mathrm{L}$ & M \\
\hline Aluminum & & $6.72 E+00$ & & & & & $6.72 \mathrm{E}+00$ & $2.49 \mathrm{E}-04$ \\
\hline Bismuth & & 4.29E-01 & & & & & 4.29E-01 & 2.05E-06 \\
\hline Chlorine & & $1.42 \mathrm{E}+03$ & & & & & $1.42 \mathrm{E}+03$ & 4.01E-02 \\
\hline Chromium & & $2.58 \mathrm{E}+01$ & & & & & $2.58 \mathrm{E}+01$ & 4.96E-04 \\
\hline Fluorine & & $2.85 E+02$ & & & & & $2.85 E+02$ & $1.50 \mathrm{E}-02$ \\
\hline Iron & & 8.08E-02 & & & & & 8.08E-02 & $1.45 \mathrm{E}-06$ \\
\hline Nickel & & $1.28 \mathrm{E}-02$ & & & & & $1.28 \mathrm{E}-02$ & 2.18E-07 \\
\hline Nitrate & & $1.39 \mathrm{E}+01$ & & & & & $1.39 \mathrm{E}+01$ & 2.24E-04 \\
\hline Nitrite & & $4.62 E+03$ & & & & & $4.62 \mathrm{E}+03$ & $1.00 \mathrm{E}-01$ \\
\hline Potassium & & $1.56 \mathrm{E}+02$ & & & & & $1.56 \mathrm{E}+02$ & 3.99E-03 \\
\hline Phosphate & & $3.24 \mathrm{E}+01$ & & & & & $3.24 \mathrm{E}+01$ & $3.41 \mathrm{E}-04$ \\
\hline Sodium & & $3.58 \mathrm{E}+03$ & & & & & $3.58 \mathrm{E}+03$ & $1.56 \mathrm{E}-01$ \\
\hline Sulfate & & $1.14 \mathrm{E}+03$ & & & & & $1.14 \mathrm{E}+03$ & 1.19E-02 \\
\hline TOC & & NR & & & & & NR & NR \\
\hline Oxalate & & NR & & & & & NR & NR \\
\hline Zirconium & & NR & & & & & NR & NR \\
\hline $\begin{array}{l}\text { Radionuclides } \\
\text { (Ci/L) }\end{array}$ & none & & none & none & none & none & $\begin{array}{l}\text { Totals } \\
\text { Tc(Ci)\& } \\
\text { Vols (gal } \\
\text { or L) } \\
\end{array}$ & \\
\hline${ }^{99} \mathrm{Tc}$ & none & $1.08 \mathrm{E}-04$ & none & none & none & none & & \\
\hline $\begin{array}{l}{ }^{99} \mathrm{Tc}(\mathrm{Ci}) \\
\text { Inventory }\end{array}$ & & $9.11 \mathrm{E}+03$ & & & & & $9.11 E+03$ & \\
\hline $\begin{array}{l}\text { Total Volume } \\
\text { (gal) }\end{array}$ & none & $2.23 \mathrm{E}+07$ & none & none & none & none & $2.23 E+07$ & \\
\hline $\begin{array}{l}\text { Total Volume } \\
\text { (L) }\end{array}$ & & $8.44 \mathrm{E}+07$ & & & & & $8.44 \mathrm{E}+07$ & \\
\hline
\end{tabular}

- See Figure 3-1 for interface locations

none $=$ no waste stream was generated during this WTP mission phase.

$\mathrm{NR}=$ not reported and assumed to be insignificant. 
The waste streams entering and then passing out of the EMF facility during DFLAW contain 9110 $\mathrm{Ci}$ of Tc with the bulk ( 7690) $\mathrm{Ci}$ being recycled to the LAW melters (interface 84b) in a relatively low volume of $5.87 \times 10^{+06} \mathrm{~L}$ and $\sim 1350 \mathrm{Ci}$ sent back to DSTs (interface 29$)$ in a larger volume $\left(1.39 \times 10^{+07}\right.$ $\mathrm{L}$. An insignificant amount of ${ }^{99} \mathrm{Tc}$ is sent from EMF to LERF/ETF (0.02 Ci; see interface 83) and from the EMF out the stack $\left(3.17 \times 10^{-05} \mathrm{Ci}\right.$; see interface 81$)$. A key operation within the EMF is an evaporator to concentrate the captured LAW melter off-gas liquids. The waste stream (interface 29) sent back to DSTs is conditioned to have Na and nitrate concentrations similar to the tank waste. Nitrite is maintained at concentrations adequate to minimize tank wall and bottom corrosion. The waste stream recycled back to the LAW melter is more concentrated in chloride, fluoride, nitrite and sulfate (interface 84b) than the waste stream sent back to DST tanks (interface 29).

The predicted Na concentration in interface 29 wastes is $4.91 \mathrm{M}$, similar to concentrations found in the DSTs. The larger portion of EMF concentrated liquid waste, which is sent back to the LAW melters is concentrated up to a Na concentration of $1.92 \mathrm{M}$. In either case should the EMF concentrated off-gas liquid wastes have Tc removed prior to recycling to the LAW melters or tank farms, the relatively high ionic strength would need to be considered. For example, direct removal of Tc by traditional anion exchange resins might be challenging; however, a plausible use of SuperLig 639 would be for the concentrated portion currently planned to recycle back to the DSTs. The waste recycled back to the LAW melters does not have a high enough Na concentration to use SuperLig 639 optimally because for optimal performance, the Na should be present at 4 to $5 \mathrm{M}$, not $1.92 \mathrm{M}$. In section 5.2 there is more discussion on Tc removal from the off-gas secondary waste stream produced during the DFLAW EMF evaporation process.

A comparable analysis of the off-gas liquid waste streams generated during the full operation of WTP-PT (Phases 3 and 4; as described at the beginning of Section 3) is found in Table 5-3 and Table 5-4. For completeness the entire mass balance of wastes entering and leaving the PT is provided in Table 5-5. Table 5-4 shows details for each waste stream entering and then leaving the PT as a function of Phase (as described in Section 3), which equates to WTP operational time.

Table 5-5 shows a very good mass balance for waste volumes and Tc entering and leaving the PT facility. Further, it is obvious from the Tc inventories that only a few of the waste streams contain enough ${ }^{99}$ Tc to be considered as good candidates for Tc removal, especially after pre-treatment of DST tank feed (interface 33a) to remove suspended solids and ${ }^{137} \mathrm{Cs}$. Most of the highly saline waste streams that leave PT (interfaces 35a, 41a, and 45) were discussed in Section 3. In Section 3 we concluded that removal of ${ }^{99} \mathrm{Tc}$ at the end of pretreatment activities in the PT facility is likely too costly and challenging (e,g., Na concentrations either too low or perhaps too high for optimal removal of pertechnetate using SuperLig 639). Removal of ${ }^{99}$ Tc from LAW wastes after removal of suspended solids and ${ }^{137} \mathrm{Cs}$ (i.e., from interfaces $41 \mathrm{a}$ and 45 likely would require diluting their Na concentrations down from 7.3 to $7.8 \mathrm{M}$ to 4 to $5 \mathrm{M}$. Thus, rather than using SuperLig 639, a different Tc removal method should be investigated. Based on the Table 5-4 and Table 5-5 data there is not enough ${ }^{99}$ Tc in the waste streams either leaving the PT facility and going to the HLW melters (interface 35a), going to LERF/ETF (interface 51), or exhausted out the stacks (interface 50 ) to warrant ${ }^{99}$ Tc removal. 
Table 5-3. Interfaces where Liquid Wastes Enter and Exit the Pre-Treatment (PT) During Full WTP Operations

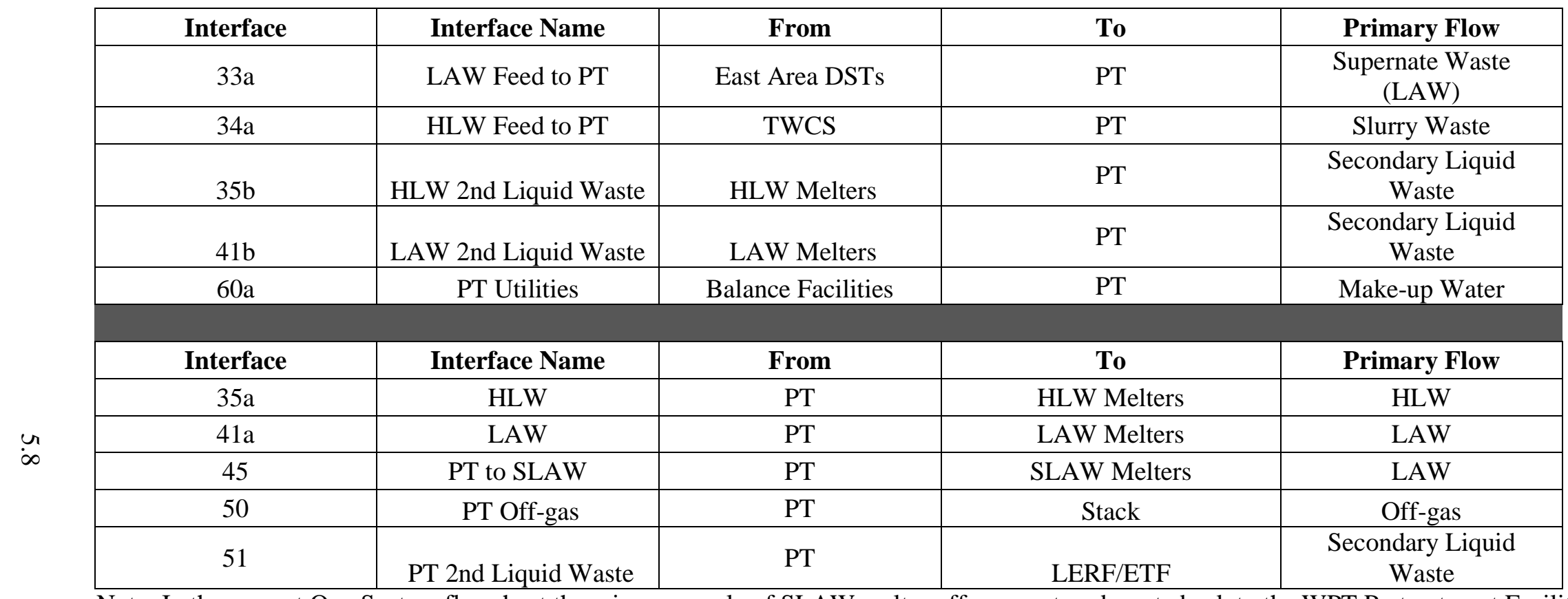

Note: In the current One System flowsheet there is no recycle of SLAW melter off-gas captured waste back to the WPT Pretreatment Facility. It is assumed that the SLAW melter facility will contain an evaporator that will concentrate SLAW off-gas captured wastes with the concentrate returned directly to the SLAW melters and evaporator condensate would liquid waste will be sent to LERF/ETF. The Tc concentration in SLAW evaporator condensate may be low enough that no separation is warranted. If Tc concentrations are higher than anticipated, then Tc removal from the SLAW evaporator condensates would have be performed at the ETF. 
Table 5-4. Volumes, Tc Concentrations, Inventory, and Chemical Concentrations of Waste Entering and Leaving the PT Facility During Full WTP Operations (Phases 3 and 4)

\begin{tabular}{|c|c|c|c|c|c|c|c|c|}
\hline & Phase 1 & $\begin{array}{c}\text { Phase } \\
2\end{array}$ & $\begin{array}{c}\text { Phase } \\
3\end{array}$ & Phase 4a & Phase 4b & Phase 4c & & \\
\hline Interface ${ }^{*}$ & $33 a$ & 33a & 33a & $33 a$ & $33 a$ & 33a & $\begin{array}{c}\text { Vol Weighted } \\
\text { Ave }\end{array}$ & $\begin{array}{c}\text { Vol } \\
\text { Weighted } \\
\text { Ave }\end{array}$ \\
\hline $\begin{array}{l}\text { Chemical } \\
\text { Components } \\
\text { (mg/L) }\end{array}$ & none & none & none & & & & $\mathrm{mg} / \mathrm{L}$ & $\mathrm{M}$ \\
\hline Aluminum & & & & $4.68 \mathrm{E}+03$ & $1.53 \mathrm{E}+03$ & $5.16 \mathrm{E}+02$ & $1.73 \mathrm{E}+03$ & $6.41 \mathrm{E}-02$ \\
\hline Bismuth & & & & $5.65 \mathrm{E}+01$ & $1.05 \mathrm{E}+02$ & $7.01 \mathrm{E}+01$ & $7.51 \mathrm{E}+01$ & 3.59E-04 \\
\hline Chlorine & & & & $3.25 \mathrm{E}+03$ & $1.67 \mathrm{E}+03$ & $8.60 \mathrm{E}+02$ & $1.61 \mathrm{E}+03$ & 4.54E-02 \\
\hline Chromium & & & & $5.53 E+02$ & $6.43 \mathrm{E}+02$ & $2.35 \mathrm{E}+02$ & $4.05 \mathrm{E}+02$ & 7.79E-03 \\
\hline Fluorine & & & & $1.07 \mathrm{E}+03$ & $2.37 \mathrm{E}+03$ & $2.07 \mathrm{E}+03$ & $1.91 \mathrm{E}+03$ & $1.00 \mathrm{E}-01$ \\
\hline Iron & & & & $5.24 \mathrm{E}+01$ & $3.01 \mathrm{E}+01$ & $1.93 \mathrm{E}+01$ & $2.96 \mathrm{E}+01$ & $5.30 \mathrm{E}-04$ \\
\hline Nickel & & & & $1.69 \mathrm{E}+00$ & $1.21 \mathrm{E}-01$ & $1.42 \mathrm{E}-02$ & 4.32E-01 & 7.36E-06 \\
\hline Nitrate & & & & $8.18 \mathrm{E}+04$ & $3.69 \mathrm{E}+04$ & $2.50 \mathrm{E}+04$ & $4.11 \mathrm{E}+04$ & 6.63E-01 \\
\hline Nitrite & & & & $1.46 \mathrm{E}+05$ & $1.36 \mathrm{E}+05$ & $1.01 \mathrm{E}+05$ & $1.20 \mathrm{E}+05$ & $2.60 \mathrm{E}+00$ \\
\hline Potassium & & & & $3.09 \mathrm{E}+03$ & $1.42 \mathrm{E}+03$ & $4.81 \mathrm{E}+02$ & $1.31 \mathrm{E}+03$ & 3.36E-02 \\
\hline Phosphate & & & & $4.28 \mathrm{E}+03$ & $6.10 \mathrm{E}+03$ & $6.90 \mathrm{E}+03$ & $6.10 \mathrm{E}+03$ & $6.42 \mathrm{E}-02$ \\
\hline Sodium & & & & $1.56 \mathrm{E}+05$ & $1.16 \mathrm{E}+05$ & $7.58 \mathrm{E}+04$ & $1.04 \mathrm{E}+05$ & $4.52 \mathrm{E}+00$ \\
\hline Sulfate & & & & $6.73 \mathrm{E}+03$ & $9.33 \mathrm{E}+03$ & $9.08 \mathrm{E}+03$ & $8.59 \mathrm{E}+03$ & 8.95E-02 \\
\hline TOC & & & & $1.69 \mathrm{E}+03$ & $1.65 \mathrm{E}+03$ & $9.38 \mathrm{E}+02$ & $1.28 \mathrm{E}+03$ & 1.07E-01 \\
\hline Oxalate & & & & $1.15 \mathrm{E}+03$ & $1.61 \mathrm{E}+03$ & $1.63 \mathrm{E}+03$ & $1.51 \mathrm{E}+03$ & $1.72 \mathrm{E}-02$ \\
\hline Zirconium & & & & NR & NR & NR & NR & NR \\
\hline $\begin{array}{l}\text { Radionuclides } \\
(\mathrm{Ci} / \mathrm{L})\end{array}$ & none & none & none & & & & $\begin{array}{l}\text { Totals: Tc } \\
\text { (Ci) \& Vol } \\
\text { (gal or L) }\end{array}$ & \\
\hline${ }^{99} \mathrm{Tc}$ & & & & $1.08 \mathrm{E}-04$ & 4.69E-05 & $2.56 \mathrm{E}-05$ & & \\
\hline $\begin{array}{l}{ }^{99} \mathrm{Tc}(\mathrm{Ci}) \\
\text { Inventory }\end{array}$ & & & & $2.85 \mathrm{E}+03$ & $1.24 \mathrm{E}+03$ & $1.53 \mathrm{E}+03$ & $5.62 \mathrm{E}+03$ & \\
\hline $\begin{array}{l}\text { Total Volume } \\
\text { (gal) }\end{array}$ & none & none & none & $6.97 E+06$ & $6.97 E+06$ & $1.58 \mathrm{E}+07$ & $2.97 \mathrm{E}+07$ & \\
\hline $\begin{array}{l}\text { Total Volume } \\
\text { (L) }\end{array}$ & & & & $2.64 \mathrm{E}+07$ & $2.64 \mathrm{E}+07$ & $5.98 \mathrm{E}+07$ & $1.13 \mathrm{E}+08$ & \\
\hline
\end{tabular}


Table 5-4. (continued)

\begin{tabular}{|c|c|c|c|c|c|c|c|c|}
\hline & Phase 1 & $\begin{array}{c}\text { Phase } \\
2\end{array}$ & Phase 3 & Phase 4a & Phase 4b & Phase $4 c$ & & \\
\hline Interface $^{*}$ & $34 a$ & $34 a$ & $34 a$ & $34 a$ & $34 a$ & $34 a$ & $\begin{array}{c}\text { Vol } \\
\text { Weighted } \\
\text { Ave }\end{array}$ & $\begin{array}{c}\text { Vol } \\
\text { Weighted } \\
\text { Ave }\end{array}$ \\
\hline $\begin{array}{l}\text { Chemical } \\
\text { Components } \\
\text { (mg/L) }\end{array}$ & none & none & & & & & $\mathrm{mg} / \mathrm{L}$ & $\mathrm{M}$ \\
\hline Aluminum & & & $2.36 \mathrm{E}+04$ & $3.44 \mathrm{E}+04$ & $2.15 E+04$ & $1.56 \mathrm{E}+04$ & $2.34 \mathrm{E}+04$ & 8.67E-01 \\
\hline Bismuth & & & $4.68 \mathrm{E}+02$ & $9.87 \mathrm{E}+02$ & $1.77 \mathrm{E}+03$ & $5.63 \mathrm{E}+02$ & $1.14 \mathrm{E}+03$ & $5.47 \mathrm{E}-03$ \\
\hline Chlorine & & & $2.14 \mathrm{E}+03$ & $1.94 \mathrm{E}+03$ & $1.03 \mathrm{E}+03$ & $7.65 \mathrm{E}+02$ & $1.27 \mathrm{E}+03$ & $3.58 \mathrm{E}-02$ \\
\hline Chromium & & & $9.44 \mathrm{E}+02$ & $2.31 \mathrm{E}+03$ & $1.14 \mathrm{E}+03$ & $1.02 \mathrm{E}+03$ & $1.40 \mathrm{E}+03$ & $2.70 \mathrm{E}-02$ \\
\hline Fluorine & & & $2.49 \mathrm{E}+03$ & $1.78 \mathrm{E}+03$ & $3.70 \mathrm{E}+03$ & $3.41 \mathrm{E}+03$ & $3.03 \mathrm{E}+03$ & $1.60 \mathrm{E}-01$ \\
\hline Iron & & & $9.91 \mathrm{E}+03$ & $3.45 \mathrm{E}+03$ & $3.25 \mathrm{E}+03$ & $1.99 \mathrm{E}+03$ & $3.39 \mathrm{E}+03$ & 6.07E-02 \\
\hline Nickel & & & $6.71 \mathrm{E}+02$ & $4.98 \mathrm{E}+02$ & $3.90 \mathrm{E}+02$ & $1.40 \mathrm{E}+02$ & $3.68 \mathrm{E}+02$ & $6.26 \mathrm{E}-03$ \\
\hline Nitrate & & & $5.02 \mathrm{E}+04$ & $3.45 \mathrm{E}+04$ & $2.48 \mathrm{E}+04$ & $2.02 \mathrm{E}+04$ & $2.78 \mathrm{E}+04$ & 4.48E-01 \\
\hline Nitrite & & & $1.10 \mathrm{E}+05$ & $9.20 \mathrm{E}+04$ & $9.57 \mathrm{E}+04$ & $7.92 \mathrm{E}+04$ & $9.11 \mathrm{E}+04$ & $1.98 \mathrm{E}+00$ \\
\hline Potassium & & & $3.07 \mathrm{E}+03$ & $2.46 \mathrm{E}+03$ & $8.83 \mathrm{E}+02$ & $4.63 \mathrm{E}+02$ & $1.33 \mathrm{E}+03$ & 3.39E-02 \\
\hline Phosphate & & & $7.16 \mathrm{E}+03$ & $7.05 \mathrm{E}+03$ & $1.48 \mathrm{E}+04$ & $1.36 \mathrm{E}+04$ & $1.19 \mathrm{E}+04$ & $1.25 \mathrm{E}-01$ \\
\hline Sodium & & & $1.21 \mathrm{E}+05$ & $1.04 \mathrm{E}+05$ & $8.83 \mathrm{E}+04$ & $7.21 \mathrm{E}+04$ & $9.01 \mathrm{E}+04$ & $3.92 \mathrm{E}+00$ \\
\hline Sulfate & & & $5.25 \mathrm{E}+03$ & $4.34 \mathrm{E}+03$ & $8.18 \mathrm{E}+03$ & $9.46 \mathrm{E}+03$ & $7.33 \mathrm{E}+03$ & 7.63E-02 \\
\hline TOC & & & $1.68 \mathrm{E}+03$ & $2.24 \mathrm{E}+03$ & $1.10 \mathrm{E}+03$ & $9.78 \mathrm{E}+02$ & $1.41 \mathrm{E}+03$ & 1.17E-01 \\
\hline Oxalate & & & $4.14 \mathrm{E}+03$ & $3.85 E+03$ & $3.58 \mathrm{E}+03$ & $5.65 \mathrm{E}+03$ & $4.26 \mathrm{E}+03$ & 4.84E-02 \\
\hline Zirconium & & & $3.27 \mathrm{E}+03$ & $1.09 \mathrm{E}+03$ & $1.73 \mathrm{E}+03$ & $2.62 \mathrm{E}+02$ & $1.26 \mathrm{E}+03$ & $1.38 \mathrm{E}-02$ \\
\hline $\begin{array}{l}\text { Radionuclides } \\
(\mathrm{Ci} / \mathrm{L})\end{array}$ & none & none & & & & & $\begin{array}{l}\text { Totals: Tc } \\
\text { (Ci )\& Vol } \\
\text { (gal or L) }\end{array}$ & \\
\hline${ }^{99} \mathrm{Tc}$ & & & 9.53E-05 & $6.15 \mathrm{E}-05$ & 2.65E-05 & 2.25E-05 & & \\
\hline $\begin{array}{l}{ }^{99} \mathrm{Tc}(\mathrm{Ci}) \\
\text { Inventory }\end{array}$ & & & $2.02 \mathrm{E}+03$ & $5.24 \mathrm{E}+03$ & $3.37 \mathrm{E}+03$ & $2.01 \mathrm{E}+03$ & $1.26 \mathrm{E}+04$ & \\
\hline $\begin{array}{l}\text { Total Volume } \\
\text { (gal) }\end{array}$ & none & none & $5.60 \mathrm{E}+06$ & $2.25 \mathrm{E}+07$ & $3.36 \mathrm{E}+07$ & $2.36 \mathrm{E}+07$ & $8.53 \mathrm{E}+07$ & \\
\hline $\begin{array}{l}\text { Total Volume } \\
\text { (L) }\end{array}$ & & & $2.12 \mathrm{E}+07$ & $8.52 \mathrm{E}+07$ & $1.27 \mathrm{E}+08$ & $8.93 \mathrm{E}+07$ & $3.23 \mathrm{E}+08$ & \\
\hline
\end{tabular}


Table 5-4. (continued)

\begin{tabular}{|c|c|c|c|c|c|c|c|c|}
\hline Interface $^{*}$ & $35 b$ & $35 b$ & $35 \mathrm{~b}$ & $35 b$ & $35 \mathrm{~b}$ & $35 \mathrm{~b}$ & $\begin{array}{c}\text { Vol } \\
\text { Weighted } \\
\text { Ave }\end{array}$ & $\begin{array}{c}\text { Vol Weighted } \\
\text { Ave }\end{array}$ \\
\hline $\begin{array}{l}\text { Chemical } \\
\text { Components } \\
(\mathrm{mg} / \mathrm{L})\end{array}$ & none & none & & & & & $\mathrm{mg} / \mathrm{L}$ & $\mathrm{M}$ \\
\hline Aluminum & & & $5.30 \mathrm{E}+01$ & $2.99 \mathrm{E}+02$ & $3.01 \mathrm{E}+02$ & $2.10 \mathrm{E}+02$ & $2.70 \mathrm{E}+02$ & $1.00 \mathrm{E}-02$ \\
\hline Bismuth & & & $3.79 \mathrm{E}+00$ & $1.04 \mathrm{E}+01$ & $2.46 \mathrm{E}+01$ & $1.39 \mathrm{E}+01$ & $1.66 \mathrm{E}+01$ & 7.95E-05 \\
\hline Chlorine & & & $6.20 \mathrm{E}+00$ & $2.10 \mathrm{E}+00$ & $1.18 \mathrm{E}+00$ & $1.38 \mathrm{E}+00$ & $1.84 \mathrm{E}+00$ & 5.19E-05 \\
\hline Chromium & & & $6.79 \mathrm{E}+00$ & $1.25 \mathrm{E}+01$ & $6.98 \mathrm{E}+00$ & $1.81 \mathrm{E}+01$ & $1.07 \mathrm{E}+01$ & 2.07E-04 \\
\hline Fluorine & & & $1.35 \mathrm{E}+02$ & $5.67 \mathrm{E}+00$ & $2.86 \mathrm{E}+01$ & $1.26 \mathrm{E}+03$ & $2.32 \mathrm{E}+02$ & 1.22E-02 \\
\hline Iron & & & $4.09 \mathrm{E}+02$ & $1.20 \mathrm{E}+02$ & $1.29 \mathrm{E}+02$ & $1.36 \mathrm{E}+02$ & $1.44 \mathrm{E}+02$ & $2.58 \mathrm{E}-03$ \\
\hline Nickel & & & $2.00 \mathrm{E}+01$ & $1.51 \mathrm{E}+01$ & $1.44 \mathrm{E}+01$ & $7.88 \mathrm{E}+00$ & $1.39 \mathrm{E}+01$ & 2.37E-04 \\
\hline Nitrate & & & $8.28 \mathrm{E}+00$ & $1.57 \mathrm{E}+01$ & $1.41 \mathrm{E}+01$ & $9.61 \mathrm{E}+00$ & $1.36 \mathrm{E}+01$ & 2.19E-04 \\
\hline Nitrite & & & $2.27 \mathrm{E}+02$ & $2.78 \mathrm{E}+02$ & $1.97 \mathrm{E}+02$ & $2.50 \mathrm{E}+02$ & $2.36 \mathrm{E}+02$ & 5.13E-03 \\
\hline Potassium & & & $3.22 \mathrm{E}+00$ & $3.48 \mathrm{E}+00$ & $1.53 \mathrm{E}+00$ & $2.24 \mathrm{E}+00$ & $2.43 \mathrm{E}+00$ & $6.22 \mathrm{E}-05$ \\
\hline Phosphate & & & $2.96 \mathrm{E}-01$ & $1.18 \mathrm{E}-01$ & $1.04 \mathrm{E}+00$ & 5.13E-01 & 5.86E-01 & 6.17E-06 \\
\hline Sodium & & & $5.94 \mathrm{E}+01$ & $5.76 \mathrm{E}+01$ & $4.45 \mathrm{E}+01$ & $9.46 \mathrm{E}+01$ & $5.83 \mathrm{E}+01$ & 2.53E-03 \\
\hline Sulfate & & & $1.25 \mathrm{E}+01$ & $6.29 \mathrm{E}+00$ & $1.50 \mathrm{E}+01$ & $2.13 \mathrm{E}+02$ & $4.47 \mathrm{E}+01$ & 4.66E-04 \\
\hline TOC & & & NR & NR & NR & NR & NR & NR \\
\hline Oxalate & & & NR & NR & NR & NR & NR & NR \\
\hline Zirconium & & & $7.50 \mathrm{E}+01$ & $2.52 \mathrm{E}+01$ & $4.49 \mathrm{E}+01$ & $1.20 \mathrm{E}+01$ & $3.44 \mathrm{E}+01$ & $3.58 \mathrm{E}-04$ \\
\hline $\begin{array}{l}\text { Radionuclides } \\
\text { (Ci/L) }\end{array}$ & none & none & & & & & $\begin{array}{l}\text { Totals: Tc } \\
\text { (Ci) \& } \\
\text { Vol (gal } \\
\text { or L) }\end{array}$ & \\
\hline${ }^{99} \mathrm{Tc}$ & & & $2.28 \mathrm{E}-07$ & $6.25 \mathrm{E}-08$ & $2.70 \mathrm{E}-08$ & 3.36E-08 & & \\
\hline $\begin{array}{l}{ }^{99} \mathrm{Tc}(\mathrm{Ci}) \\
\text { Inventory }\end{array}$ & & & 9.84E-01 & $1.54 \mathrm{E}+00$ & 8.12E-01 & 3.96E-01 & $3.73 E+00$ & \\
\hline $\begin{array}{l}\text { Total Volume } \\
\text { (gal) }\end{array}$ & none & none & $1.14 \mathrm{E}+06$ & $6.52 E+06$ & $7.94 \mathrm{E}+06$ & $3.11 E+06$ & $1.87 \mathrm{E}+07$ & \\
\hline $\begin{array}{l}\text { Total Volume } \\
\text { (L) }\end{array}$ & & & $4.32 E+06$ & $2.47 \mathrm{E}+07$ & $3.01 \mathrm{E}+07$ & $1.18 \mathrm{E}+07$ & $7.08 \mathrm{E}+07$ & \\
\hline
\end{tabular}


Table 5-4. (continued)

\begin{tabular}{|c|c|c|c|c|c|c|c|c|}
\hline & Phase 1 & Phase 2 & Phase 3 & Phase 4a & Phase 4b & Phase 4c & & \\
\hline Interface $^{*}$ & $41 \mathrm{~b}$ & $41 \mathrm{~b}$ & $41 \mathrm{~b}$ & $41 \mathrm{~b}$ & $41 \mathrm{~b}$ & $41 \mathrm{~b}$ & $\begin{array}{c}\text { Vol } \\
\text { Weighted } \\
\text { Ave } \\
\end{array}$ & $\begin{array}{c}\text { Vol } \\
\text { Weighted } \\
\text { Ave } \\
\end{array}$ \\
\hline $\begin{array}{l}\text { Chemical } \\
\text { Components } \\
\text { (mg/L) }\end{array}$ & none & none & & & & & $\mathrm{mg} / \mathrm{L}$ & $\mathrm{M}$ \\
\hline Aluminum & & & $1.53 \mathrm{E}+01$ & $1.49 \mathrm{E}+01$ & $1.05 \mathrm{E}+01$ & $8.18 \mathrm{E}+00$ & $1.17 \mathrm{E}+01$ & 4.32E-04 \\
\hline Bismuth & & & 7.75E-01 & $1.28 \mathrm{E}+00$ & $1.32 \mathrm{E}+00$ & 9.99E-01 & $1.16 \mathrm{E}+00$ & 5.56E-06 \\
\hline Chlorine & & & $5.21 \mathrm{E}+02$ & $5.77 \mathrm{E}+02$ & $3.19 \mathrm{E}+02$ & $2.11 \mathrm{E}+02$ & $3.88 \mathrm{E}+02$ & $1.09 \mathrm{E}-02$ \\
\hline Chromium & & & $2.33 \mathrm{E}+01$ & $4.79 \mathrm{E}+01$ & $3.56 \mathrm{E}+01$ & $2.41 \mathrm{E}+01$ & $3.49 \mathrm{E}+01$ & 6.72E-04 \\
\hline Fluorine & & & $6.05 \mathrm{E}+02$ & $5.03 \mathrm{E}+02$ & $1.01 \mathrm{E}+03$ & $9.19 \mathrm{E}+02$ & $7.85 \mathrm{E}+02$ & 4.13E-02 \\
\hline Iron & & & $1.36 \mathrm{E}-01$ & $1.48 \mathrm{E}-01$ & $1.34 \mathrm{E}-01$ & 8.77E-02 & $1.25 \mathrm{E}-01$ & 2.24E-06 \\
\hline Nickel & & & $2.96 \mathrm{E}-02$ & 2.99E-02 & $1.96 \mathrm{E}-02$ & $1.43 \mathrm{E}-02$ & 2.22E-02 & 3.79E-07 \\
\hline Nitrate & & & $2.78 \mathrm{E}+01$ & $1.83 \mathrm{E}+01$ & $5.58 \mathrm{E}-01$ & $1.82 \mathrm{E}-01$ & $8.60 \mathrm{E}+00$ & $1.39 \mathrm{E}-04$ \\
\hline Nitrite & & & $2.04 \mathrm{E}+03$ & $2.21 \mathrm{E}+03$ & $1.84 \mathrm{E}+03$ & $1.31 \mathrm{E}+03$ & $1.82 \mathrm{E}+03$ & 3.95E-02 \\
\hline Potassium & & & $5.99 \mathrm{E}+01$ & $5.14 \mathrm{E}+01$ & $2.52 \mathrm{E}+01$ & $1.06 \mathrm{E}+01$ & $3.24 \mathrm{E}+01$ & 8.29E-04 \\
\hline Phosphate & & & $2.93 \mathrm{E}+01$ & $3.10 \mathrm{E}+01$ & $6.96 \mathrm{E}+01$ & $6.44 \mathrm{E}+01$ & $5.21 \mathrm{E}+01$ & 5.49E-04 \\
\hline Sodium & & & $2.21 \mathrm{E}+03$ & $2.29 \mathrm{E}+03$ & $2.32 \mathrm{E}+03$ & $1.97 \mathrm{E}+03$ & $2.20 \mathrm{E}+03$ & 9.55E-02 \\
\hline Sulfate & & & $2.20 \mathrm{E}+01$ & $1.24 \mathrm{E}+02$ & $1.12 \mathrm{E}+03$ & $1.67 \mathrm{E}+03$ & $8.65 E+02$ & $9.01 \mathrm{E}-03$ \\
\hline TOC & & & NR & NR & NR & NR & NR & NR \\
\hline Oxalate & & & NR & NR & NR & NR & NR & NR \\
\hline Zirconium & & & NR & NR & NR & NR & NR & NR \\
\hline $\begin{array}{l}\text { Radionuclides } \\
\text { (Ci/L) }\end{array}$ & none & none & & & & & & \\
\hline${ }^{99} \mathrm{Tc}$ & & & 3.81E-05 & 3.38E-05 & 1.32E-05 & 9.89E-06 & $\begin{array}{l}\text { Totals: Tc } \\
\text { (Ci) \& Vol } \\
\text { (gal or L) }\end{array}$ & \\
\hline $\begin{array}{l}{ }^{99} \mathrm{Tc}(\mathrm{Ci}) \\
\text { Inventory }\end{array}$ & & & $1.57 E+03$ & $4.70 \mathrm{E}+03$ & $1.72 E+03$ & $1.28 \mathrm{E}+03$ & $9.27 E+03$ & \\
\hline $\begin{array}{l}\text { Total Volume } \\
\text { (gal) }\end{array}$ & none & none & $1.09 \mathrm{E}+07$ & $3.67 \mathrm{E}+07$ & $3.44 \mathrm{E}+07$ & $3.43 E+07$ & $1.16 \mathrm{E}+08$ & \\
\hline $\begin{array}{l}\text { Total Volume } \\
\text { (L) }\end{array}$ & & & $4.13 \mathrm{E}+07$ & $1.39 \mathrm{E}+08$ & $1.30 \mathrm{E}+08$ & $1.30 \mathrm{E}+08$ & $4.40 \mathrm{E}+08$ & \\
\hline
\end{tabular}


Table 5-4. (continued)

\begin{tabular}{|c|c|c|c|c|c|c|c|c|}
\hline & Phase 1 & $\begin{array}{c}\text { Phase } \\
2\end{array}$ & Phase 3 & Phase 4a & Phase 4b & Phase $4 c$ & & \\
\hline Interface $^{*}$ & $60 \mathrm{a}$ & $60 \mathrm{a}$ & $60 \mathrm{a}$ & $60 \mathrm{a}$ & $60 \mathrm{a}$ & $60 \mathrm{a}$ & $\begin{array}{c}\text { Vol } \\
\text { Weighted } \\
\text { Ave }\end{array}$ & $\begin{array}{c}\text { Vol } \\
\text { Weighted } \\
\text { Ave }\end{array}$ \\
\hline $\begin{array}{l}\text { Chemical } \\
\text { Components } \\
(\mathrm{mg} / \mathrm{L})\end{array}$ & none & none & & & & & $\mathrm{mg} / \mathrm{L}$ & M \\
\hline Aluminum & & & NR & NR & NR & NR & & \\
\hline Bismuth & & & NR & NR & NR & NR & & \\
\hline Chlorine & & & NR & NR & NR & NR & & \\
\hline Chromium & & & NR & NR & NR & NR & & \\
\hline Fluorine & & & NR & NR & NR & NR & & \\
\hline Iron & & & NR & NR & NR & NR & & \\
\hline Nickel & & & NR & NR & NR & NR & & \\
\hline Nitrate & & & $3.59 \mathrm{E}+01$ & $3.80 \mathrm{E}+01$ & $4.19 \mathrm{E}+01$ & $3.52 \mathrm{E}+01$ & $3.86 \mathrm{E}+01$ & $6.23 \mathrm{E}-04$ \\
\hline Nitrite & & & $1.73 \mathrm{E}+04$ & $1.72 \mathrm{E}+04$ & $1.55 \mathrm{E}+04$ & $1.43 \mathrm{E}+04$ & $1.60 \mathrm{E}+04$ & 3.47E-01 \\
\hline Potassium & & & NR & NR & NR & NR & & \\
\hline Phosphate & & & NR & NR & NR & NR & & \\
\hline Sodium & & & $1.18 \mathrm{E}+05$ & $1.14 \mathrm{E}+05$ & $1.12 \mathrm{E}+05$ & $1.23 \mathrm{E}+05$ & $1.16 \mathrm{E}+05$ & $5.03 \mathrm{E}+00$ \\
\hline Sulfate & & & NR & NR & NR & NR & & \\
\hline TOC & & & NR & NR & NR & NR & & \\
\hline Oxalate & & & NR & NR & NR & NR & & \\
\hline Zirconium & & & NR & NR & NR & NR & & \\
\hline $\begin{array}{l}\text { Radionuclides } \\
(\mathrm{Ci} / \mathrm{L})\end{array}$ & none & none & NR & NR & NR & NR & & \\
\hline${ }^{99} \mathrm{Tc}$ & & & 0 & 0 & 0 & 0 & & \\
\hline $\begin{array}{l}{ }^{99} \mathrm{Tc}(\mathrm{Ci}) \\
\text { Inventory }\end{array}$ & & & 0 & 0 & 0 & 0 & 0 & \\
\hline $\begin{array}{l}\text { Total Volume } \\
\text { (gal) }\end{array}$ & none & none & $4.54 \mathrm{E}+06$ & $2.00 \mathrm{E}+07$ & $2.08 \mathrm{E}+07$ & $1.29 \mathrm{E}+07$ & $5.82 \mathrm{E}+07$ & \\
\hline $\begin{array}{l}\text { Total Volume } \\
\text { (L) }\end{array}$ & & & $1.72 \mathrm{E}+07$ & $7.57 \mathrm{E}+07$ & $7.87 \mathrm{E}+07$ & $4.88 \mathrm{E}+07$ & $2.20 \mathrm{E}+08$ & \\
\hline
\end{tabular}


Table 5-4. (continued)

\begin{tabular}{|c|c|c|c|c|c|c|c|c|}
\hline & Phase 1 & Phase 2 & Phase 3 & Phase 4a & Phase 4B & Phase 4C & $\begin{array}{c}\text { Vol } \\
\text { Weighted } \\
\text { Ave } \\
\end{array}$ & $\begin{array}{c}\text { Vol } \\
\text { Weighted } \\
\text { Ave } \\
\end{array}$ \\
\hline Interface $^{*}$ & $35 a$ & $35 a$ & $35 a$ & $35 a$ & $35 a$ & $35 a$ & $\mathrm{mg} / \mathrm{L}$ & $\mathrm{M}$ \\
\hline $\begin{array}{c}\text { Chemical } \\
\text { Components } \\
(\mathrm{mg} / \mathrm{L})\end{array}$ & none & none & & & & & & \\
\hline Aluminum & & & $8.96 \mathrm{E}+03$ & $4.60 \mathrm{E}+04$ & $4.60 \mathrm{E}+04$ & $3.07 \mathrm{E}+04$ & $4.13 E+04$ & $1.53 \mathrm{E}+00$ \\
\hline Bismuth & & & $1.34 \mathrm{E}+03$ & $3.32 \mathrm{E}+03$ & $7.86 \mathrm{E}+03$ & $4.21 \mathrm{E}+03$ & $5.29 \mathrm{E}+03$ & 2.53E-02 \\
\hline Chlorine & & & $1.12 \mathrm{E}+01$ & $3.45 \mathrm{E}+00$ & $1.94 \mathrm{E}+00$ & $2.15 E+00$ & $3.02 \mathrm{E}+00$ & 8.50E-05 \\
\hline Chromium & & & $6.86 \mathrm{E}+02$ & $1.16 \mathrm{E}+03$ & $6.42 \mathrm{E}+02$ & $1.58 \mathrm{E}+03$ & $9.88 \mathrm{E}+02$ & $1.90 \mathrm{E}-02$ \\
\hline Fluorine & & & $2.18 \mathrm{E}+02$ & $8.12 \mathrm{E}+00$ & $4.21 \mathrm{E}+01$ & $1.76 \mathrm{E}+03$ & $3.39 \mathrm{E}+02$ & $1.78 \mathrm{E}-02$ \\
\hline Iron & & & $5.35 E+04$ & $1.43 \mathrm{E}+04$ & $1.53 \mathrm{E}+04$ & $1.55 E+04$ & $1.71 \mathrm{E}+04$ & 3.06E-01 \\
\hline Nickel & & & $3.06 \mathrm{E}+03$ & $2.10 \mathrm{E}+03$ & $2.00 \mathrm{E}+03$ & $1.05 \mathrm{E}+03$ & $1.93 \mathrm{E}+03$ & 3.28E-02 \\
\hline Nitrate & & & $3.49 \mathrm{E}+02$ & $1.89 \mathrm{E}+02$ & $1.50 \mathrm{E}+02$ & $1.97 \mathrm{E}+02$ & $1.83 \mathrm{E}+02$ & 2.95E-03 \\
\hline Nitrite & & & $1.12 \mathrm{E}+04$ & $1.12 \mathrm{E}+04$ & $8.03 \mathrm{E}+03$ & $1.54 \mathrm{E}+04$ & $1.06 \mathrm{E}+04$ & 2.30E-01 \\
\hline Potassium & & & $1.35 \mathrm{E}+02$ & $1.31 \mathrm{E}+02$ & $5.79 \mathrm{E}+01$ & $8.03 E+01$ & $9.15 \mathrm{E}+01$ & 2.34E-03 \\
\hline Phosphate & & & $3.65 E+01$ & $1.32 \mathrm{E}+01$ & $1.17 \mathrm{E}+02$ & $5.36 \mathrm{E}+01$ & $6.54 \mathrm{E}+01$ & 6.89E-04 \\
\hline Sodium & & & $7.83 \mathrm{E}+03$ & $6.87 \mathrm{E}+03$ & $5.31 \mathrm{E}+03$ & $1.07 \mathrm{E}+04$ & $6.93 \mathrm{E}+03$ & 3.01E-01 \\
\hline Sulfate & & & $2.79 \mathrm{E}+01$ & $1.28 \mathrm{E}+01$ & $3.10 \mathrm{E}+01$ & $4.11 \mathrm{E}+02$ & $9.07 \mathrm{E}+01$ & 9.44E-04 \\
\hline TOC & & & $1.95 \mathrm{E}+01$ & $9.19 \mathrm{E}+00$ & $6.36 \mathrm{E}+00$ & $6.91 \mathrm{E}+00$ & $8.17 \mathrm{E}+00$ & 8.51E-05 \\
\hline Oxalate & & & $7.86 \mathrm{E}+02$ & $8.17 \mathrm{E}+02$ & $2.21 \mathrm{E}+02$ & $1.33 E+03$ & $6.53 \mathrm{E}+02$ & 6.80E-03 \\
\hline Zirconium & & & $1.63 \mathrm{E}+04$ & $4.96 \mathrm{E}+03$ & $8.84 \mathrm{E}+03$ & $2.25 \mathrm{E}+03$ & $6.76 \mathrm{E}+03$ & $7.04 \mathrm{E}-02$ \\
\hline $\begin{array}{c}\text { Radionuclides } \\
(\mathrm{Ci} / \mathrm{L})\end{array}$ & none & none & & & & & & \\
\hline${ }^{99} \mathrm{Tc}$ & & & 4.71E-07 & 1.18E-07 & 5.11E-08 & $6.00 \mathrm{E}-08$ & $\begin{array}{l}\text { Totals: Tc } \\
\text { (Ci) \& } \\
\text { Vol (gal } \\
\text { or L) }\end{array}$ & \\
\hline $\begin{array}{l}{ }^{99} \mathrm{Tc}(\mathrm{Ci}) \\
\text { Inventory }\end{array}$ & & & $1.57 \mathrm{E}+00$ & $2.47 \mathrm{E}+00$ & $1.30 \mathrm{E}+00$ & $6.29 \mathrm{E}-01$ & $5.98 \mathrm{E}+00$ & \\
\hline $\begin{array}{c}\text { Total Volume } \\
\text { (gal) }\end{array}$ & none & none & $8.83 E+05$ & $5.53 \mathrm{E}+06$ & $6.73 \mathrm{E}+06$ & $2.77 \mathrm{E}+06$ & $1.59 \mathrm{E}+07$ & \\
\hline $\begin{array}{c}\text { Total Volume } \\
\text { (L) }\end{array}$ & & & $3.34 \mathrm{E}+06$ & $2.09 \mathrm{E}+07$ & $2.55 \mathrm{E}+07$ & $1.05 \mathrm{E}+07$ & $6.02 \mathrm{E}+07$ & \\
\hline
\end{tabular}


Table 5-4. (continued)

\begin{tabular}{|c|c|c|c|c|c|c|c|c|}
\hline & Phase 1 & $\begin{array}{c}\text { Phase } \\
2 \\
\end{array}$ & Phase 3 & Phase 4a & Phase 4B & Phase 4C & $\begin{array}{c}\text { Vol } \\
\text { Weighted } \\
\text { Ave } \\
\end{array}$ & $\begin{array}{c}\text { Vol } \\
\text { Weighted } \\
\text { Ave } \\
\end{array}$ \\
\hline Interface $^{*}$ & $41 a$ & 41a & $41 a$ & $41 a$ & $41 a$ & $41 a$ & $\mathrm{mg} / \mathrm{L}$ & M \\
\hline $\begin{array}{l}\text { Chemical } \\
\text { Components } \\
\text { (mg/L) }\end{array}$ & none & none & & & & & & \\
\hline Aluminum & & & $1.78 \mathrm{E}+04$ & $1.72 \mathrm{E}+04$ & $1.31 \mathrm{E}+04$ & $1.31 \mathrm{E}+04$ & $1.50 \mathrm{E}+04$ & 5.57E-01 \\
\hline Bismuth & & & $9.41 \mathrm{E}+01$ & $1.52 \mathrm{E}+02$ & $1.72 \mathrm{E}+02$ & $1.65 \mathrm{E}+02$ & $1.55 \mathrm{E}+02$ & 7.42E-04 \\
\hline Chlorine & & & $2.59 \mathrm{E}+03$ & $2.84 \mathrm{E}+03$ & $1.72 \mathrm{E}+03$ & $1.44 \mathrm{E}+03$ & $2.14 \mathrm{E}+03$ & 6.04E-02 \\
\hline Chromium & & & $7.43 \mathrm{E}+02$ & $1.51 \mathrm{E}+03$ & $1.23 \mathrm{E}+03$ & $1.06 \mathrm{E}+03$ & $1.24 \mathrm{E}+03$ & 2.38E-02 \\
\hline Fluorine & & & $2.78 \mathrm{E}+03$ & $2.27 \mathrm{E}+03$ & $5.00 \mathrm{E}+03$ & $5.77 \mathrm{E}+03$ & $3.99 \mathrm{E}+03$ & 2.10E-01 \\
\hline Iron & & & $1.65 \mathrm{E}+02$ & $1.77 \mathrm{E}+02$ & $1.74 \mathrm{E}+02$ & $1.46 \mathrm{E}+02$ & $1.67 \mathrm{E}+02$ & $3.00 \mathrm{E}-03$ \\
\hline Nickel & & & $7.03 \mathrm{E}+00$ & $7.00 \mathrm{E}+00$ & $5.02 \mathrm{E}+00$ & $4.66 \mathrm{E}+00$ & $5.84 \mathrm{E}+00$ & 9.96E-05 \\
\hline Nitrate & & & $3.98 \mathrm{E}+04$ & $4.37 \mathrm{E}+04$ & $3.18 \mathrm{E}+04$ & $3.06 \mathrm{E}+04$ & $3.66 \mathrm{E}+04$ & $5.90 \mathrm{E}-01$ \\
\hline Nitrite & & & $1.04 \mathrm{E}+05$ & $1.09 \mathrm{E}+05$ & $1.29 \mathrm{E}+05$ & $1.28 \mathrm{E}+05$ & $1.19 \mathrm{E}+05$ & $2.59 \mathrm{E}+00$ \\
\hline Potassium & & & $2.69 \mathrm{E}+03$ & $2.28 \mathrm{E}+03$ & $1.22 \mathrm{E}+03$ & $6.53 \mathrm{E}+02$ & $1.61 \mathrm{E}+03$ & 4.13E-02 \\
\hline Phosphate & & & $5.91 \mathrm{E}+03$ & $6.17 \mathrm{E}+03$ & $1.52 \mathrm{E}+04$ & $1.78 \mathrm{E}+04$ & $1.17 \mathrm{E}+04$ & 1.23E-01 \\
\hline Sodium & & & $1.83 \mathrm{E}+05$ & $1.82 \mathrm{E}+05$ & $1.79 \mathrm{E}+05$ & $1.77 \mathrm{E}+05$ & $1.80 \mathrm{E}+05$ & $7.83 \mathrm{E}+00$ \\
\hline Sulfate & & & $4.37 \mathrm{E}+03$ & $4.71 \mathrm{E}+03$ & $9.96 \mathrm{E}+03$ & $1.55 \mathrm{E}+04$ & $8.84 \mathrm{E}+03$ & $9.21 \mathrm{E}-02$ \\
\hline TOC & & & $1.43 \mathrm{E}+03$ & $1.77 \mathrm{E}+03$ & $1.36 \mathrm{E}+03$ & $1.35 \mathrm{E}+03$ & $1.51 \mathrm{E}+03$ & 1.26E-01 \\
\hline Oxalate & & & $3.44 \mathrm{E}+03$ & $2.64 \mathrm{E}+03$ & $3.62 E+03$ & $6.83 E+03$ & $4.02 \mathrm{E}+03$ & 4.57E-02 \\
\hline Zirconium & & & NR & NR & NR & NR & NR & NR \\
\hline $\begin{array}{l}\text { Radionuclides } \\
(\mathrm{Ci} / \mathrm{L})\end{array}$ & none & none & & & & & & \\
\hline${ }^{99} \mathrm{Tc}$ & & & $1.36 \mathrm{E}-04$ & 1.19E-04 & 5.09E-05 & 4.85E-05 & $\begin{array}{l}\text { Totals: Tc } \\
\text { (Ci) \& } \\
\text { Vol (gal } \\
\text { or L) }\end{array}$ & \\
\hline $\begin{array}{l}{ }^{99} \mathrm{Tc}(\mathrm{Ci}) \\
\text { Inventory }\end{array}$ & & & $2.52 E+03$ & $7.48 E+03$ & $2.74 \mathrm{E}+03$ & $2.06 \mathrm{E}+03$ & $1.48 \mathrm{E}+04$ & \\
\hline $\begin{array}{l}\text { Total Volume } \\
\text { (gal) }\end{array}$ & none & none & $4.90 \mathrm{E}+06$ & $1.66 \mathrm{E}+07$ & $1.42 \mathrm{E}+07$ & $1.12 \mathrm{E}+07$ & $4.69 \mathrm{E}+07$ & \\
\hline $\begin{array}{l}\text { Total } \\
\text { Volume (L) }\end{array}$ & & & $1.85 \mathrm{E}+07$ & $6.28 \mathrm{E}+07$ & $5.38 \mathrm{E}+07$ & $4.24 \mathrm{E}+07$ & $1.78 \mathrm{E}+08$ & \\
\hline
\end{tabular}


Table 5-4. (continued)

\begin{tabular}{|c|c|c|c|c|c|c|c|c|}
\hline & Phase 1 & Phase 2 & Phase 3 & Phase 4a & Phase 4B & Phase 4C & $\begin{array}{c}\text { Vol } \\
\text { Weighted } \\
\text { Ave }\end{array}$ & $\begin{array}{c}\text { Vol } \\
\text { Weighted } \\
\text { Ave }\end{array}$ \\
\hline Interface $^{*}$ & 45 & 45 & 45 & 45 & 45 & 45 & $\mathrm{mg} / \mathrm{L}$ & M \\
\hline $\begin{array}{c}\text { Chemical } \\
\text { Components } \\
\text { (mg/L) }\end{array}$ & none & none & none & & & & & \\
\hline Aluminum & & & & $1.71 \mathrm{E}+04$ & $1.24 \mathrm{E}+04$ & $1.00 \mathrm{E}+04$ & $1.29 \mathrm{E}+04$ & $4.79 \mathrm{E}-01$ \\
\hline Bismuth & & & & $1.44 \mathrm{E}+02$ & $1.70 \mathrm{E}+02$ & $1.61 \mathrm{E}+02$ & $1.50 \mathrm{E}+02$ & 7.18E-04 \\
\hline Chlorine & & & & $2.66 \mathrm{E}+03$ & $1.61 \mathrm{E}+03$ & $1.60 \mathrm{E}+03$ & $1.88 \mathrm{E}+03$ & 5.31E-02 \\
\hline Chromium & & & & $1.60 \mathrm{E}+03$ & $1.11 \mathrm{E}+03$ & $8.36 \mathrm{E}+02$ & $1.17 \mathrm{E}+03$ & 2.25E-02 \\
\hline Fluorine & & & & $1.98 \mathrm{E}+03$ & $5.09 \mathrm{E}+03$ & $5.51 \mathrm{E}+03$ & $3.80 \mathrm{E}+03$ & $2.00 \mathrm{E}-01$ \\
\hline Iron & & & & $1.75 \mathrm{E}+02$ & $1.64 \mathrm{E}+02$ & $1.14 \mathrm{E}+02$ & $1.50 \mathrm{E}+02$ & $2.69 \mathrm{E}-03$ \\
\hline Nickel & & & & $7.34 \mathrm{E}+00$ & $4.77 \mathrm{E}+00$ & $3.31 \mathrm{E}+00$ & $5.14 \mathrm{E}+00$ & 8.76E-05 \\
\hline Nitrate & & & & $4.28 \mathrm{E}+04$ & $3.17 E+04$ & $3.76 \mathrm{E}+04$ & $3.48 \mathrm{E}+04$ & $5.62 \mathrm{E}-01$ \\
\hline Nitrite & & & & $1.05 \mathrm{E}+05$ & $1.28 \mathrm{E}+05$ & $1.56 \mathrm{E}+05$ & $1.18 \mathrm{E}+05$ & $2.56 \mathrm{E}+00$ \\
\hline Potassium & & & & $2.63 \mathrm{E}+03$ & $1.15 E+03$ & $8.02 E+02$ & $1.54 \mathrm{E}+03$ & $3.94 \mathrm{E}-02$ \\
\hline Phosphate & & & & $5.76 \mathrm{E}+03$ & $1.58 \mathrm{E}+04$ & $1.62 \mathrm{E}+04$ & $1.15 \mathrm{E}+04$ & $1.21 \mathrm{E}-01$ \\
\hline Sodium & & & & $1.79 \mathrm{E}+05$ & $1.76 \mathrm{E}+05$ & $1.75 E+05$ & $1.67 \mathrm{E}+05$ & $7.27 \mathrm{E}+00$ \\
\hline Sulfate & & & & $4.56 \mathrm{E}+03$ & $1.12 \mathrm{E}+04$ & $1.77 \mathrm{E}+04$ & $9.40 \mathrm{E}+03$ & $9.79 \mathrm{E}-02$ \\
\hline TOC & & & & $2.05 E+03$ & $1.38 \mathrm{E}+03$ & $1.59 \mathrm{E}+03$ & $1.57 \mathrm{E}+03$ & $1.64 \mathrm{E}-02$ \\
\hline Oxalate & & & & $2.76 \mathrm{E}+03$ & $3.59 \mathrm{E}+03$ & $4.90 \mathrm{E}+03$ & $3.33 E+03$ & $3.47 \mathrm{E}-02$ \\
\hline \multicolumn{9}{|l|}{ Zirconium } \\
\hline $\begin{array}{c}\text { Radionuclides } \\
\text { (Ci/L) }\end{array}$ & none & none & none & & & & & \\
\hline${ }^{99} \mathrm{Tc}$ & & & & 9.95E-05 & 4.69E-05 & 5.10E-05 & $\begin{array}{l}\text { Totals: Tc } \\
\text { (Ci) \& Vol } \\
\text { (gal or L) }\end{array}$ & \\
\hline $\begin{array}{l}{ }^{99} \mathrm{Tc}(\mathrm{Ci}) \\
\text { Inventory }\end{array}$ & & & & $6.25 \mathrm{E}+03$ & $3.59 \mathrm{E}+03$ & $2.88 \mathrm{E}+03$ & $1.27 \mathrm{E}+04$ & \\
\hline $\begin{array}{c}\text { Total Volume } \\
\text { (gal) }\end{array}$ & none & none & none & $1.66 \mathrm{E}+07$ & $2.02 \mathrm{E}+07$ & $1.49 \mathrm{E}+07$ & $5.17 \mathrm{E}+07$ & \\
\hline $\begin{array}{c}\text { Total Volume } \\
\text { (L) }\end{array}$ & & & & $6.28 \mathrm{E}+07$ & $7.65 \mathrm{E}+07$ & $5.64 \mathrm{E}+07$ & $1.96 \mathrm{E}+08$ & \\
\hline
\end{tabular}


Table 5-4. (continued)

\begin{tabular}{|c|c|c|c|c|c|c|c|c|}
\hline & Phase 1 & Phase 2 & Phase 3 & Phase 4a & Phase 4b & Phase 4c & & \\
\hline Interface $^{*}$ & 50 & 50 & 50 & 50 & 50 & 50 & $\begin{array}{c}\text { Vol } \\
\text { Weighted } \\
\text { Ave }\end{array}$ & $\begin{array}{c}\text { Vol } \\
\text { Weighted } \\
\text { Ave }\end{array}$ \\
\hline $\begin{array}{l}\text { Chemical } \\
\text { Components } \\
\text { (mg/L) }\end{array}$ & none & none & & & & & $\mathrm{mg} / \mathrm{L}$ & $\mathrm{M}$ \\
\hline Aluminum & & & 6.38E-02 & 4.50E-02 & 3.85E-02 & 3.61E-02 & 4.17E-02 & $1.55 \mathrm{E}-06$ \\
\hline Bismuth & & & 3.71E-01 & 4.19E-01 & 4.97E-01 & 4.99E-01 & 4.64E-01 & $2.22 \mathrm{E}-06$ \\
\hline Chlorine & & & $5.98 \mathrm{E}-01$ & 4.51E-01 & 1.95E-01 & $1.43 \mathrm{E}-01$ & 2.89E-01 & 8.15E-06 \\
\hline Chromium & & & $1.90 \mathrm{E}-02$ & 4.30E-02 & $2.98 \mathrm{E}-02$ & 2.63E-02 & $3.20 \mathrm{E}-02$ & 6.15E-07 \\
\hline Fluorine & & & $2.84 \mathrm{E}+01$ & $1.70 \mathrm{E}+01$ & $2.67 \mathrm{E}+01$ & $3.06 \mathrm{E}+01$ & $2.50 \mathrm{E}+01$ & $1.32 \mathrm{E}-03$ \\
\hline Iron & & & $3.11 \mathrm{E}+01$ & $2.61 \mathrm{E}+01$ & $2.78 \mathrm{E}+01$ & $2.28 \mathrm{E}+01$ & $2.61 \mathrm{E}+01$ & 4.68E-04 \\
\hline Nickel & & & 8.02E-01 & $5.42 \mathrm{E}-01$ & 4.03E-01 & 3.75E-01 & 4.68E-01 & 7.97E-06 \\
\hline Nitrate & & & $4.08 \mathrm{E}-03$ & 3.01E-03 & $2.29 \mathrm{E}-03$ & $2.43 \mathrm{E}-03$ & 2.69E-03 & 4.33E-08 \\
\hline Nitrite & & & 2.79E-03 & 2.22E-03 & $2.30 \mathrm{E}-03$ & 2.17E-03 & 2.28E-03 & 4.95E-08 \\
\hline Potassium & & & 4.00E-01 & 2.42E-01 & 1.17E-01 & $6.04 \mathrm{E}-02$ & $1.61 \mathrm{E}-01$ & 4.11E-06 \\
\hline Phosphate & & & 4.46E-01 & 3.12E-01 & 8.72E-01 & $1.10 \mathrm{E}+00$ & 7.34E-01 & 7.73E-06 \\
\hline Sodium & & & $9.73 \mathrm{E}+00$ & $7.19 \mathrm{E}+00$ & $7.13 \mathrm{E}+00$ & $7.05 \mathrm{E}+00$ & $7.33 \mathrm{E}+00$ & 3.19E-04 \\
\hline Sulfate & & & $1.09 \mathrm{E}+00$ & $1.11 \mathrm{E}+00$ & $3.49 \mathrm{E}+00$ & $6.06 \mathrm{E}+00$ & $3.32 \mathrm{E}+00$ & 3.45E-05 \\
\hline TOC & & & $1.82 \mathrm{E}+04$ & $1.76 \mathrm{E}+04$ & $1.37 \mathrm{E}+04$ & $1.46 \mathrm{E}+04$ & $1.55 \mathrm{E}+04$ & $1.61 \mathrm{E}-01$ \\
\hline Oxalate & & & $1.77 \mathrm{E}+05$ & $1.81 \mathrm{E}+05$ & $2.17 \mathrm{E}+05$ & $3.10 \mathrm{E}+05$ & $2.30 \mathrm{E}+05$ & $2.39 \mathrm{E}+00$ \\
\hline Zirconium & & & NR & NR & NR & NR & NR & NR \\
\hline $\begin{array}{l}\text { Radionuclides } \\
(\mathrm{Ci} / \mathrm{L})\end{array}$ & none & none & & & & & $\begin{array}{l}\text { Totals: Tc } \\
\text { (Ci) \& Vol } \\
\text { (gal or L) }\end{array}$ & \\
\hline${ }^{99} \mathrm{Tc}$ & & & $1.32 \mathrm{E}-08$ & 7.82E-09 & 2.39E-09 & $1.98 \mathrm{E}-09$ & & \\
\hline $\begin{array}{l}{ }^{99} \mathrm{Tc}(\mathrm{Ci}) \\
\text { Inventory }\end{array}$ & & & $2.88 \mathrm{E}-05$ & 6.66E-05 & $2.24 \mathrm{E}-05$ & $1.59 \mathrm{E}-05$ & $1.34 \mathrm{E}-04$ & \\
\hline $\begin{array}{l}\text { Total Volume } \\
\text { (gal) }\end{array}$ & none & none & $5.77 \mathrm{E}+02$ & $2.25 E+03$ & $2.48 \mathrm{E}+03$ & $2.12 \mathrm{E}+03$ & $7.43 E+03$ & \\
\hline $\begin{array}{l}\text { Total Volume } \\
\text { (L) }\end{array}$ & & & $2.18 \mathrm{E}+03$ & $8.52 \mathrm{E}+03$ & $9.39 \mathrm{E}+03$ & $8.03 E+03$ & $2.81 E+04$ & \\
\hline
\end{tabular}


Table 5-4. (continued)

\begin{tabular}{|c|c|c|c|c|c|c|c|c|}
\hline & $\begin{array}{c}\text { Phase } \\
1\end{array}$ & $\begin{array}{l}\text { Phase } \\
2\end{array}$ & Phase 3 & Phase 4a & Phase 4B & Phase 4C & & \\
\hline Interface & 51 & 51 & 51 & 51 & 51 & 51 & $\begin{array}{c}\text { Vol } \\
\text { Weighted } \\
\text { Ave }\end{array}$ & $\begin{array}{c}\text { Vol } \\
\text { Weighted } \\
\text { Ave }\end{array}$ \\
\hline $\begin{array}{l}\text { Chemical } \\
\text { Components } \\
\text { (mg/L) }\end{array}$ & none & none & & & & & $\mathrm{mg} / \mathrm{L}$ & M \\
\hline Aluminum & & & 8.66E-04 & $6.09 \mathrm{E}-04$ & $5.04 \mathrm{E}-04$ & $4.66 \mathrm{E}-04$ & $5.48 \mathrm{E}-04$ & 2.03E-08 \\
\hline Bismuth & & & 2.45E-01 & $2.51 \mathrm{E}-01$ & 2.89E-01 & 3.05E-01 & 2.80E-01 & $1.34 \mathrm{E}-06$ \\
\hline Chlorine & & & $5.44 \mathrm{E}-01$ & 4.93E-01 & 2.19E-01 & 1.53E-01 & 2.99E-01 & $8.45 \mathrm{E}-06$ \\
\hline Chromium & & & $2.26 \mathrm{E}-03$ & $4.98 \mathrm{E}-03$ & $3.40 \mathrm{E}-03$ & 2.91E-03 & $3.61 \mathrm{E}-03$ & $6.94 \mathrm{E}-08$ \\
\hline Fluorine & & & $2.26 \mathrm{E}+00$ & $1.38 \mathrm{E}+00$ & $2.14 \mathrm{E}+00$ & $2.29 \mathrm{E}+00$ & $1.98 \mathrm{E}+00$ & $1.04 \mathrm{E}-04$ \\
\hline Iron & & & 3.37E-01 & $2.80 \mathrm{E}-01$ & 2.94E-01 & 2.32E-01 & 2.73E-01 & $4.90 \mathrm{E}-06$ \\
\hline Nickel & & & 1.09E-02 & 7.36E-03 & 5.31E-03 & $4.88 \mathrm{E}-03$ & $6.16 \mathrm{E}-03$ & $1.05 \mathrm{E}-07$ \\
\hline Nitrate & & & $9.05 \mathrm{E}-04$ & 6.64E-04 & 4.92E-04 & $6.11 \mathrm{E}-04$ & 6.09E-04 & 9.82E-09 \\
\hline Nitrite & & & $1.26 \mathrm{E}+02$ & $1.16 \mathrm{E}+02$ & $9.26 \mathrm{E}+01$ & $7.31 \mathrm{E}+01$ & $9.55 \mathrm{E}+01$ & $2.08 \mathrm{E}-03$ \\
\hline Potassium & & & $5.47 \mathrm{E}-03$ & $3.22 \mathrm{E}-03$ & $1.52 \mathrm{E}-03$ & 9.05E-04 & 2.09E-03 & $5.36 \mathrm{E}-08$ \\
\hline Phosphate & & & $6.23 \mathrm{E}-03$ & 4.30E-03 & $1.14 \mathrm{E}-02$ & 1.54E-02 & 1.03E-02 & $1.08 \mathrm{E}-07$ \\
\hline Sodium & & & $2.26 \mathrm{E}+02$ & $2.09 \mathrm{E}+02$ & $1.67 \mathrm{E}+02$ & $1.64 \mathrm{E}+02$ & $1.82 \mathrm{E}+02$ & 7.92E-03 \\
\hline Sulfate & & & 1.09E-01 & $1.54 \mathrm{E}-01$ & 7.06E-01 & $1.20 \mathrm{E}+00$ & 6.63E-01 & $6.90 \mathrm{E}-06$ \\
\hline TOC & & & $6.20 \mathrm{E}+00$ & $5.83 \mathrm{E}+00$ & $4.54 \mathrm{E}+00$ & $5.54 \mathrm{E}+00$ & $5.34 \mathrm{E}+00$ & 4.45E-04 \\
\hline Oxalate & & & $6.08 \mathrm{E}+01$ & $5.97 \mathrm{E}+01$ & $6.93 \mathrm{E}+01$ & $1.02 \mathrm{E}+02$ & $7.63 \mathrm{E}+01$ & 8.67E-04 \\
\hline Zirconium & & & NR & NR & NR & NR & NR & NR \\
\hline $\begin{array}{l}\text { Radionuclides } \\
(\mathrm{Ci} / \mathrm{L})\end{array}$ & none & none & & & & & & \\
\hline${ }^{99} \mathrm{Tc}$ & none & none & $1.97 \mathrm{E}-10$ & $1.13 \mathrm{E}-10$ & $3.18 \mathrm{E}-11$ & 2.96E-11 & $\begin{array}{l}\text { Totals: Tc } \\
\text { (Ci) \& Vol. } \\
\text { (gal or L) }\end{array}$ & \\
\hline $\begin{array}{l}\text { 99Tc (Ci) } \\
\text { Inventory }\end{array}$ & & & $1.07 \mathrm{E}-02$ & $2.40 \mathrm{E}-02$ & 7.74E-03 & 7.01E-03 & $4.94 \mathrm{E}-02$ & \\
\hline $\begin{array}{l}\text { Total Volume } \\
\text { (gal) }\end{array}$ & none & none & $1.43 E+07$ & $5.60 \mathrm{E}+07$ & $6.43 \mathrm{E}+07$ & $6.26 \mathrm{E}+07$ & $1.97 \mathrm{E}+08$ & \\
\hline $\begin{array}{l}\text { Total Volume } \\
\text { (L) }\end{array}$ & & & $5.41 \mathrm{E}+07$ & $2.12 \mathrm{E}+08$ & $2.43 \mathrm{E}+08$ & $2.37 E+08$ & $7.46 \mathrm{E}+08$ & \\
\hline
\end{tabular}


Table 5-5. Mass Balance of Waste Volumes and ${ }^{99}$ Tc Entering and Exiting the PT Facility

\begin{tabular}{|c|c|c|c|c|c|}
\hline Into: & interface $^{*}$ & vol (gal) & $\operatorname{vol}(\mathrm{L})$ & Tc (Ci) & Weighted Ave Na(M) \\
\hline PT & 33a & $2.97 \mathrm{E}+07$ & $1.13 \mathrm{E}+08$ & $5.62 E+03$ & 4.52 \\
\hline $\mathrm{PT}$ & $34 a$ & $8.53 \mathrm{E}+07$ & $3.23 \mathrm{E}+08$ & $1.26 \mathrm{E}+04$ & 3.92 \\
\hline PT & $35 b$ & $1.87 \mathrm{E}+07$ & $7.08 \mathrm{E}+07$ & $3.73 \mathrm{E}+00$ & 0.003 \\
\hline PT & $41 \mathrm{~b}$ & $1.16 \mathrm{E}+08$ & $4.40 \mathrm{E}+08$ & $9.27 \mathrm{E}+03$ & 0.096 \\
\hline \multirow[t]{2}{*}{$\mathrm{PT}$} & $60 \mathrm{a}$ & $5.82 \mathrm{E}+07$ & $2.20 \mathrm{E}+08$ & 0 & 5.03 \\
\hline & Totals & $3.08 \mathrm{E}+08$ & $1.17 E+09$ & $2.75 E+04$ & \\
\hline \multicolumn{6}{|l|}{ Out Of } \\
\hline $\mathrm{PT}$ & interface & vol (gal) & $\operatorname{vol}(\mathrm{L})$ & Tc (Ci) & \\
\hline PT & $35 a$ & $1.59 \mathrm{E}+07$ & $6.02 \mathrm{E}+07$ & $5.98 \mathrm{E}+00$ & 0.301 \\
\hline PT & $41 \mathrm{a}$ & $4.69 \mathrm{E}+07$ & $1.78 \mathrm{E}+08$ & $1.48 \mathrm{E}+04$ & 7.83 \\
\hline $\mathrm{PT}$ & 45 & $5.17 \mathrm{E}+07$ & $1.96 \mathrm{E}+08$ & $1.27 \mathrm{E}+04$ & 7.27 \\
\hline $\mathrm{PT}$ & 50 & $7.43 \mathrm{E}+03$ & $2.81 \mathrm{E}+04$ & $1.34 \mathrm{E}-04$ & 0.0003 \\
\hline \multirow[t]{2}{*}{ PT } & 51 & $1.97 \mathrm{E}+08$ & $7.46 \mathrm{E}+08$ & 4.94E-02 & 0.008 \\
\hline & Totals & $3.12 E+08$ & $1.18 \mathrm{E}+09$ & $2.75 E+04$ & \\
\hline $\begin{array}{l}\text { Mass Balance (Out- } \\
\text { In)/In \% }\end{array}$ & & $1.2 \%$ & $1.2 \%$ & $0.0 \%$ & \\
\hline
\end{tabular}


In summary, based on Table 5-4 and Table 5-5, the PT facility mass balance for Tc shows that the HLW melter facility returns 70.8 million liters of off-gas captured liquid waste to the PT facility over Phases 3 and 4 but the Tc content in this waste stream is very low $(\sim 3.72 \mathrm{Ci})$. The chemical composition of the HLW off-gas liquid waste stream is dominated by fluoride and sodium with a total ionic strength of about $0.04 \mathrm{M}$. The LLW melters return 440 million liters of off-gas captured liquid waste to the PT facility over Phases 3 and 4 and the projected Tc content is substantial ( 9270 Ci). The chemical composition of the LLW off-gas liquid waste stream is dominated by fluoride, chloride and sodium with a total ionic strength of about $0.12 \mathrm{M}$.

Currently, The One System flow-sheet does not have the assumed SLAW melters recycling off-gas wastes back to PT. Rather those wastes are processed through an evaporator that is part of the proposed SLAW vitrification facility. Captured SLAW melter off-gas liquid wastes are sent through the SLAW evaporator and the concentrate is continually recycled through the SLAW melters. SLAW evaporator condensate is sent directly to LERF/ETF (interface 48). Inspection of the projected mass of ${ }^{99} \mathrm{Tc}$ leaving the SLAW evaporator as condensates and being sent to LERF/ETF in waste stream 48 is inconsequential (0.12 Ci).

The inventory of ${ }^{99}$ Tc entering the SLAW melters is projected to be 15,330 Ci (2630 Ci from LAWPS and 12,700 Ci from PT). The inventory of ${ }^{99} \mathrm{Tc}$ in the immobilized SLAW glass is projected to be 14,900 $\mathrm{Ci}$ and about $0.12 \mathrm{Ci}$ being sent to LERF/ETF and $<0.001 \mathrm{Ci}$ being exhausted out the stack. So there appears to be a misbalance between the ${ }^{99}$ Tc entering the SLAW melters and leaving the melters as secondary wastes, exhaust and immobilized glass of $\sim 400 \mathrm{Ci}$. This shortfall is $2.6 \%$ of the projected ${ }^{99} \mathrm{Tc}$ entering the SLAW melters. More importantly the current One System flow sheet assumes that almost all ${ }^{99}$ Tc entering the SLAW melters gets incorporated into SLAW glass by continuous recycle of captured off-gas waste streams after being concentrated in an evaporator that is within the proposed SLAW facility.

Based on all the waste projections of volumes and more importantly ${ }^{99} \mathrm{Tc}$ and major chemical compositions (concentrations), the most likely waste stream from which ${ }^{99}$ Tc would be best removed is the captured off-gas liquid wastes from the LAW melters as it is returned to the PT for reconcentration/modification for mixing with fresh LAW feed. This is interface 41b waste. Its projected volumes, Tc and major chemical concentrations as a function of WTP operations phases are shown in Table 5-4. Summary information on total projected volumes, total ${ }^{99}$ Tc inventory and average Na concentration is found in Table 5-5. Based on these projections there would be an opportunity to remove $\sim 9300 \mathrm{Ci}$ of ${ }^{99} \mathrm{Tc}$ from a dilute solution containing $\sim 0.1 \mathrm{M}$ Na at some location within the PT or at a nearby location prior to any re-concentration by evaporation. One challenge would be the projected volume is $\mathbf{4 4 0}$ million liters that would need to be treated. A similar Tc removal location would be inside the SLAW facility after the melter off-gas waste stream is captured either before or after this dilute waste stream is processed in the SLAW evaporator. At this time the One System mass flow-sheet does not provide volumes, Tc inventories or waste compositions. However, the estimates for interface could be multiplied by the ratio of original LAW feed projected to be sent to the SLAW melters divided by original LAW feed destined to be sent to the LAW melters. Many of the Tc removal techniques described in Section 6 should be capable of removing ${ }^{99}$ Tc from the captured off-gas dilute waste streams. If the ${ }^{99} \mathrm{Tc}$ from this off-gas captured waste stream was first re-concentrated by evaporation it might be possible to 
use SuperLig 639 as long as the alkali metal (generally $\mathrm{Na}$ ) is set in the range of 4 to $5 \mathrm{M}$. This would require a 40 to 50 -fold reduction in the volume of dilute waste with the $41 \mathrm{~b}$ composition to get the waste stream in the optimal state for effective ${ }^{99}$ Tc removal by SuperLig 639. The form of ${ }^{99} \mathrm{Tc}$ in the off-gas captured waste stream 41b is most likely pertechnetate, which is the Tc species that SuperLig 639 removes.

Other scientists have also been studying methods of removing Tc from WTP off-gas condensates and flush waters generated during both DFLAW and normal WTP PT operations. Taylor-Pashow et al. (2015) studied Tc removal from a DFLAW off-gas simulant and Taylor-Pashow et al. (2014a,b) studied Tc removal from a WTP-LAW melter off-gas simulant. A summary of their work is provided in the next two subsections.

\subsection{SRNL Studies on Off-gas Simulants for Fully Operational WTP}

Once the WTP PT and LAW vitrification facility is fully operational (Phase 3), it will generate an aqueous condensate recycle stream (LAW Off-Gas Condensate) from the off-gas system. The baseline plan for disposition of this stream is to send it back to the Pretreatment Facility (PT), where it will be concentrated by evaporation, then mixed with new LAW feed and then recycled to the LAW vitrification facility (melters) again. The off-gas waste stream is near neutral $\mathrm{pH}$, and will likely contain some insoluble solids from melter carryover. Soluble components are expected to be mostly sodium and ammonium salts of nitrate, chloride, and fluoride. Eliminating this off-gas stream from recycling within PT would also decrease the LAW vitrification mission duration and quantity of glass waste generated. Because this recycle stream contains halides and sulfate, which are only marginally soluble in glass, these components accumulate in the condensate stream, exacerbating their impact on the number of LAW glass containers that must be produced. The halide concentrations can be so high that extra LAW glass needs to be made to accommodate the halides in the glass. Approximately $32 \%$ of the sodium in ILAW (glass product) comes from glass formers used to make the extra glass to dilute the halides to acceptable concentrations in the final LAW glass. If key contaminant risk drivers such as Tc were removed from the off-gas condensates and SBS and WESP flush water, then this waste stream could be ultimately diverted from recycle back through the LAW melters and likely the resultant liquid waste stream (with ${ }^{99} \mathrm{Tc}$ removed) could be disposed to facilities such as the ETF. However, sending this Tc-removed waste stream to ETF would cause the halide concentration in the ETF evaporator to increase substantially, which is expected to impact corrosion (Lueck and Mcnamar 2008). Likewise, the content of other radionuclides could substantially increase, and might challenge existing ETF treatment capabilities (May et al. 2009). If some of the radionuclides are removed from the off-gas condensate and flush water waste stream in an alternate process and the decontaminated liquid was then sent to the ETF, the fluoride, sulfate, and chloride would be purged from the LAW system, yielding substantial benefits to the overall WTP mission.

Taylor-Pashow et al. (2014a) generated a WTP off-gas simulant shown in Table 5-6 and proceeded to study various methods to remove radionuclides $\left({ }^{137} \mathrm{Cs},{ }^{90} \mathrm{Sr},{ }^{99} \mathrm{Tc}, \mathrm{U}\right.$, and $\left.\mathrm{Pu}\right)$. The simulant was produced based on models, calculations, and comparison with pilot-scale melter tests. The projected solution chemistry and radionuclide content were based on version 7.4 of the Hanford Tank Waste Operations Simulator (HTWOS) modeling of the flow sheet (Belsher et al. 2012) performed by WRPS [SVF-2732]. The HTWOS model run scenario selected as the basis for the solution chemistry was full operation of all of the WTP facilities, including supplemental LAW melters (in the assumed second LAW facility 
(SLAW). More detail on the synthesis of the simulant used by Taylor-Pashow et al. (2014a) has been documented in Adamson et al. (2013) and McCabe et al. (2013; Appendix A-1) gives selected output from the HTWOS SVF-2732 predictions. These HTWOS predictions are shown in the right side of Table 5-6. The radionuclide contents were based on the HTWOS model run by WRPS [SVF-2732] and the insoluble solids composition was primarily based on analysis of LAW Off-Gas Condensate obtained from pilot-scale simulant melter testing (Matlack et al. 2006). Since the HTWOS computer model does not account for carryover of solids by physical entrainment, the insoluble solids added to the simulant

Table 5-6. Measured Concentrations of Constituents Present in the Off-gas Simulant Used in Testing (Taylor-Pashow et al. 2014a)

\begin{tabular}{|c|c|c|c|c|c|c|}
\hline \multirow{2}{*}{ Constituent } & \multicolumn{2}{|c|}{$\begin{array}{l}\text { Measured WTP } \\
\text { PT off-gas }\end{array}$} & \multicolumn{4}{|c|}{$\begin{array}{c}\text { HTWOS Predicted Off-gas } \\
\text { (McCabe et al., 2013, Appendix A-1) }\end{array}$} \\
\hline & ppm & $\mathrm{M}$ & Constituent & ppm & $\mathrm{M}$ & Charge $^{\text {a) }}$ \\
\hline Tc & 1.99 & & ${ }^{99} \mathrm{Tc}$ & 2.44 & $2.47 \mathrm{E}-05$ & $-2.47 \mathrm{E}-05$ \\
\hline $\mathrm{Al}$ & $<0.1$ & $<3.70 \mathrm{E}-05$ & $\mathrm{AlO}_{4}^{-}$ & 101 & $1.51 \mathrm{E}-03$ & $-1.51 \mathrm{E}-03$ \\
\hline $\mathrm{B}^{3+}$ & 253 & 2.34E-02 & $\mathrm{B}^{3+}$ & 0.0422 & 3.90E-06 & 1.17E-05 \\
\hline $\mathrm{Ca}^{2+}$ & $<0.1$ & $<2.50 \mathrm{E}-06$ & $\mathrm{Ca}^{2+}$ & 0.128 & 3.19E-06 & 6.39E-06 \\
\hline $\mathrm{Cr}$ & 91 & $1.75 \mathrm{E}-03$ & $\mathrm{CrO}_{4}{ }^{2-}$ & 204 & $1.76 \mathrm{E}-03$ & -0.00352 \\
\hline $\mathrm{Fe}^{3+}$ & $<0.1$ & $<1.79 \mathrm{E}-06$ & $\mathrm{Fe}^{3+}$ & 0.147 & $2.63 \mathrm{E}-06$ & $7.90 \mathrm{E}-06$ \\
\hline $\mathrm{K}^{+}$ & 150 & 3.84E-03 & $\mathrm{K}^{+}$ & 115 & $2.94 \mathrm{E}-03$ & $2.94 \mathrm{E}-03$ \\
\hline $\mathrm{Li}^{+}$ & 80.3 & $1.16 \mathrm{E}-02$ & $\mathrm{Li}^{+}$ & 0.0053 & 7.64E-07 & 7.64E-07 \\
\hline $\mathrm{Mg}^{2+}$ & $<0.1$ & $<4.11 \mathrm{E}-06$ & $\mathrm{Mg}^{2+}$ & 0.000432 & $1.78 \mathrm{E}-08$ & $3.55 \mathrm{E}-08$ \\
\hline $\mathrm{Na}^{+}$ & 2980 & 1.30E-01 & $\mathrm{Na}^{+}$ & 2290 & 9.96E-02 & 9.96E-02 \\
\hline $\mathrm{NH}_{4}^{+}$ & 1773 & $1.04 \mathrm{E}-01$ & $\mathrm{NH}_{4}^{+}$ & 1510 & 8.88E-02 & $8.88 \mathrm{E}-02$ \\
\hline $\mathrm{P}$ & $<10$ & $<3.23 \mathrm{E}-04$ & & & & \\
\hline $\mathrm{S}$ & 832 & $2.59 \mathrm{E}-02$ & & & & \\
\hline $\mathrm{Si}^{4+}$ & 52.7 & $1.88 \mathrm{E}-03$ & $\mathrm{Si}^{4+}$ & 1.03 & 3.67E-05 & $1.47 \mathrm{E}-04$ \\
\hline $\mathrm{Ti}^{4+}$ & $<0.1$ & $<2.09 \mathrm{E}-06$ & $\mathrm{Ti}^{4+}$ & 0.000961 & $2.01 \mathrm{E}-08$ & $8.03 \mathrm{E}-08$ \\
\hline $\mathrm{Zn}^{2+}$ & 28.6 & $4.38 \mathrm{E}-04$ & $\mathrm{Zn}^{2+}$ & 0.00306 & 4.68E-08 & $9.36 \mathrm{E}-08$ \\
\hline $\mathrm{Zr}^{4+}$ & $<0.1$ & $<1.10 \mathrm{E}-06$ & $\mathrm{Zr}^{4+}$ & 0.0057 & $6.25 \mathrm{E}-08$ & $2.50 \mathrm{E}-07$ \\
\hline $\mathrm{F}^{-}$ & 1250 & $6.58 \mathrm{E}-02$ & $\mathrm{~F}^{-}$ & 1450 & 7.63E-02 & -7.63E-02 \\
\hline $\mathrm{Cl}^{-}$ & 934 & $2.63 \mathrm{E}-02$ & $\mathrm{Cl}^{-}$ & 950 & $2.68 \mathrm{E}-02$ & $-2.68 \mathrm{E}-02$ \\
\hline $\mathrm{NO}_{2}^{-}$ & $<10$ & $<2.17 \mathrm{E}-04$ & $\mathrm{NO}_{2}^{-}$ & 11 & 2.39E-04 & $-2.39 \mathrm{E}-04$ \\
\hline $\mathrm{NO}_{3}^{-}$ & 4900 & 7.90E-02 & $\mathrm{NO}_{3}^{-}$ & 5530 & 8.92E-02 & -8.92E-02 \\
\hline $\mathrm{SO}_{4}{ }^{2-}$ & 2410 & $2.51 \mathrm{E}-02$ & $\mathrm{SO}_{4}{ }^{2-}$ & 2340 & $2.44 \mathrm{E}-02$ & $-4.88 \mathrm{E}-02$ \\
\hline $\mathrm{PO}_{4}^{3-}$ & $<10$ & $<1.05 \mathrm{E}-04$ & $\mathrm{PO}_{4}^{3-}$ & 21.5 & $2.26 \mathrm{E}-04$ & $-6.79 \mathrm{E}-04$ \\
\hline $\mathrm{CO}_{3}{ }^{2-}$ & NR & NR & $\mathrm{CO}_{3}{ }^{2-}$ & 0 & 0 & \\
\hline $\mathrm{pH}$ & 7.9 & & & & & \\
\hline & & & $\mathrm{H}^{+}$ & 30.4 & 3.04E-02 & 3.04E-02 \\
\hline & & & $\mathrm{OH}^{-}$ & 0.00022 & $1.29 \mathrm{E}-08$ & $-1.29 \mathrm{E}-08$ \\
\hline Cats & & & & & & $2.22 \mathrm{E}-01$ \\
\hline Anions & & & & & & $2.47 \mathrm{E}-01$ \\
\hline
\end{tabular}

a) Charge = electrical charge for cited constituent in equivalents per liter $(\mathrm{N})$

Yellow highlight $=$ constituents added by dissolution of glass formers; blue highlight $=$ major cations; green highlight = major anions; red highlight is Tc data; and NR= not reported (not analyzed). 
were based on results from pilot-scale melter off-gas system testing Matlack et al. (2006). Those results showed that the insoluble solids were high in iron, indicating that they are largely glass-formers added to the LAW feed. After collecting and comparing this information, the major individual components were chosen based on scientific judgment.

The aqueous phase was prepared from dissolution of reagent-grade chemicals and glass forming solids (see Table 5-7) were added to the dissolved chemical solution. The simulant containing the glass formers was stirred for several days at room temperature. The solids were then removed by filtration with a $0.45-\mu \mathrm{m}$ filter. The filtrate $\mathrm{pH}$ was adjusted to $7.3 \pm 0.3$ with $\sim 50$ drops of concentrated nitric acid to be within the range measured in pilot-scale off-gas condensates tests. The presence of measurable boron, lithium, silicon, and zinc in the final simulant were due to dissolution of some of the glass former solids. Radionuclides were then added to the filtered off-gas simulant at predicted concentrations from the HTWOS model. Of interest to us here is the predicted Tc concentration of $2.44 \mathrm{mg} / \mathrm{L}$. This is the average Tc concentration from the HTWOS predictions (the low to max range for predicted Tc in this waste stream is 1.2 to $3.6 \mathrm{mg} / \mathrm{L}$ (see Appendix A-1 in McCabe et al. 2013). This amount of Tc (2.44 $\mathrm{mg} / \mathrm{L}$ ) was added as ammonium pertechnetate but after stirring for $\sim 6$ days, a 1-L batch of radionuclide spiked simulant was filtered with a $0.45-\mu \mathrm{m}$ filter and the measured Tc was $1.99 \mathrm{mg} / \mathrm{L}$.

Table 5-7. Glass Forming Solids Added to Off-gas Simulant (later filtered out) from Taylor-Pashow et al. (2014a)

\begin{tabular}{|l|l|l|}
\hline Mineral & Formula & Mass (g)/L simulant \\
\hline kyanite & $\mathrm{Al}_{2} \mathrm{SiO}_{5}$ & 0.745 \\
\hline borax & $\mathrm{Na}_{2} \mathrm{~B}_{4} \mathrm{O}_{7} \cdot 10 \mathrm{H}_{2} \mathrm{O}$ & 0.012 \\
\hline boric acid & $\mathrm{H}_{3} \mathrm{BO}_{3}$ & 1.430 \\
\hline wollastonite & $\mathrm{CaSiO}_{3}$ & 0.772 \\
\hline hematite & $\mathrm{Fe}_{2} \mathrm{O}_{3}$ & 0.430 \\
\hline lithium carbonate & $\mathrm{Li}_{2} \mathrm{CO}_{3}$ & 0.392 \\
\hline forsterite olivine & $\mathrm{Mg}_{2} \mathrm{SiO}_{4}-\mathrm{Fe}_{2} \mathrm{SiO}_{4}$ & 0.257 \\
\hline sodium carbonate & $\mathrm{Na}_{2} \mathrm{CO}_{3}$ & 0.003 \\
\hline silica & $\mathrm{SiO}_{2}$ & 2.857 \\
\hline rutile & $\mathrm{TiO}_{2}$ & 0.114 \\
\hline zinc oxide & $\mathrm{ZnO}$ & 0.286 \\
\hline zircon & $\mathrm{ZrSiO}_{4}$ & 0.372 \\
\hline sucrose & $\mathrm{C}_{12} \mathrm{H}_{22} \mathrm{O}_{11}$ & 0 \\
\hline & $\mathrm{Total}$ & 7.670 \\
\hline
\end{tabular}

Table 5-6 shows that the "theoretical" and measured WTP off-gas simulant is dominated by sodium and ammonium cations and nitrate, fluoride, chloride and sulfate anions. The simulant was used in batch experiments where several reductant/sorbents combinations were used to remove Tc. The reductant/sorbents tested were $\mathrm{SnCl}_{2}$-hydroxyapatite, $\mathrm{SnCl}_{2}$-sodium oxalate, and $\mathrm{FeSO}_{4}$-hydroxyapatite.

In general, the radionuclide removal tests were performed by adding a small amount of each sorbent/reagent to separate poly bottles, followed by addition of $20 \mathrm{~mL}$ of the radioactive simulant solution to each. The bottles were then agitated in a shaker at $\sim 25^{\circ} \mathrm{C}$ for the specified time (the Tc 
reduction test samples were sampled at two time points; $2 \mathrm{hr}$ and $18 \mathrm{hr}$ ). Each sample was then filtered through a $0.1-\mu \mathrm{m}$ filter. The filtrate was then analyzed for the radionuclide of interest. Test results indicate that excellent removal of Tc was achieved using $\mathrm{Sn}(\mathrm{II}) \mathrm{Cl}_{2}$ as a reductant, combined with sorption onto hydroxyapatite, even in the presence of air and at room temperature. The specific test conditions were to add equal masses of the $\mathrm{Sn}(\mathrm{II}) \mathrm{Cl}_{2}$ and hydroxyapatite to the Tc-spiked simulant at a solution to solid ratio of 167g:1g (equivalent to $1 \mathrm{~L}$ simulant to $3 \mathrm{~g} \mathrm{Sn(II)Cl}{ }_{2}$ plus $3 \mathrm{~g}$ hydroxyapatite).

This Sn(II) reducing agent coupled with hydroxyapatite sorbent process was very effective at neutral $\mathrm{pH}$; removing essentially all of the Tc (to below the method detection limit of $5 \mu \mathrm{g} / \mathrm{L}$ ) within $2 \mathrm{hrs}$. This was equivalent to a Tc Decontamination Factor (DF) $>577$. This Sn(II) reducing agent-hydroxyapatite mixture was less effective at removing Tc when the off-gas simulant was adjusted to an alkaline $\mathrm{pH}=12$; here the DF for Tc was reduced to 3.4 to 3.6. It was also observed that chromium in the simulant coprecipitates with the Tc during the $\mathrm{SnCl}_{2}$ reduction.

\subsection{SRNL Studies on Off-gas Simulants for Direct Feed LAW}

Nash et al. (2014) created a DFLAW off-gas simulant that differs somewhat from the off-gas simulant prepared by Taylor-Pashow et al. (2014a) for the full operation phase of WTP. Differences can be observed by comparing Table 5-6 with Table 5-8. The Direct Feed LAW (DFLAW) simulant is based on modeling of only the first several years of operation of the LAW melters (prior to start-up of the PT facility). The waste feed composition to the LAW melters during DFLAW will be different because the waste originates in fewer tanks, and the internal streams generated during processing within the PT Facility, such as sludge washing and leaching, will not be included (because PT will not be operational at the beginning of DFLAW). Since the DFLAW waste feed going to the LAW melters is different, the offgas condensate will be different.

The projected solution chemistry and radionuclide content of the DFLAW off-gas were based on version 7.4 of the Hanford Tank Waste Operations Simulator (HTWOS) modeling of the flow sheet (Belsher et al. 2012) performed by WRPS [SVF-3002, Rev. 1 for DFLAW]. First the HTWOS predicted, off-gas simulant was prepared using reagent grade chemicals and then the same glass formers were added as for the previous simulant discussed in Section 5.1 (shown in Table 5-7 and mixed for four days at ambient temperature of $\sim 23{ }^{\circ} \mathrm{C}$. After mixing the glass former solids, the solution $\mathrm{pH}$ was adjusted to 7.0-7.5 with $0.18 \mathrm{M}$ nitric acid, mixed for over one hour, and then filtered with a $0.45-\mu \mathrm{m}$ filter.

Radionuclides (Am, Cs, Pu, Sr, Tc, and U) were then added to the filtered solution; allowed to equilibrate for several days and then filtered through a $0.45-\mu \mathrm{m}$ filter. Of interest to this review was the addition of Tc as ammonium pertechnetate at a mass concentration of $6.08 \mathrm{mg} / \mathrm{L} .^{13}$ The spiked DFLAW off-gas simulant was then analyzed for composition and results are shown in Table 5-8.

Chemical analysis results match the target compositions reasonably well. Although boron, lithium, silicon, zinc, and carbonate were not in the aqueous simulant based on HTWOS predictions, they are present in the solution due to addition of the glass former solids and the subsequent dissolution of some of the glass formers. It appears that all of the lithium carbonate and boric acid dissolved, but only a small amount of silicon and zinc chemical reagents dissolved, which is expected due to their relatively low

\footnotetext{
${ }^{13}$ The HTWOS predicted ${ }^{99}$ Tc for the DFLAW off-gas waste stream is $10.2 \mathrm{mg}$ Tc/L (see Nash et al., 2014; Table
} 2-1) but they only added $6.08 \mathrm{mg} / \mathrm{L}$. 
solubilities. Additionally, the analyzed soluble fluoride in the DFLAW off-gas simulant was about 50 $\mathrm{mg} / \mathrm{L}$ lower than the target, and the phosphate is much lower than the target. Presumably, both fluoride and phosphate precipitate from the simulant solution. The target concentration for soluble aluminum was $8.7 \mathrm{mg} / \mathrm{L}$, based on computer modeling. However, consistent with prior results for the WTP off-gas simulant discussed in Section 5.1, the aluminum is not soluble in either simulant.

Table 5-8. DFLAW Off-gas Simulant (measured) and HTWOS Predicted Composition

\begin{tabular}{|c|c|c|c|c|c|c|}
\hline & \multicolumn{2}{|c|}{$\begin{array}{l}\text { Measured DFLAW } \\
\text { off-gas }\end{array}$} & \multicolumn{4}{|c|}{$\begin{array}{l}\text { HTWOS Predicted DFLAW Off-gas } \\
\text { (Nash et al., 2014) }\end{array}$} \\
\hline Constituent & ppm & $\mathrm{M}$ & Constituent & ppm & $\mathrm{M}$ & Charge \\
\hline Tc & 4.73 & & ${ }^{99} \mathrm{Tc}$ & 10.20 & $1.03 \mathrm{E}-04$ & $-1.03 \mathrm{E}-04$ \\
\hline $\mathrm{Al}$ & $<0.31$ & $<1.15 \mathrm{E}-04$ & $\mathrm{AlO}_{4}^{-}$ & 29.32 & 4.40E-04 & $-4.40 \mathrm{E}-04$ \\
\hline $\mathrm{B}^{3+}$ & 243 & $2.25 \mathrm{E}-02$ & $\mathrm{~B}^{3+}$ & minimal & & \\
\hline $\mathrm{Ca}^{2+}$ & 3.67 & $9.16 \mathrm{E}-05$ & $\mathrm{Ca}^{2+}$ & minimal & & \\
\hline $\mathrm{Cr}$ & 28.4 & $5.46 \mathrm{E}-04$ & $\mathrm{CrO}_{4}{ }^{2-}$ & 30 & 2.59E-04 & -0.00052 \\
\hline $\mathrm{Fe}^{3+}$ & $<0.07$ & $<1.253 \mathrm{E}-06$ & $\mathrm{Fe}^{3+}$ & minimal & & \\
\hline $\mathrm{K}^{+}$ & 242 & 6.19E-03 & $\mathrm{K}^{+}$ & 239 & $6.11 \mathrm{E}-03$ & $6.11 \mathrm{E}-03$ \\
\hline $\mathrm{Li}^{+}$ & 72 & $1.04 \mathrm{E}-02$ & $\mathrm{Li}^{+}$ & minimal & & \\
\hline $\mathrm{Mg}^{2+}$ & 1.01 & 4.15E-05 & $\mathrm{Mg}^{2+}$ & minimal & & \\
\hline $\mathrm{Na}^{+}$ & 2660 & $1.16 \mathrm{E}-01$ & $\mathrm{Na}^{+}$ & 2780 & $1.21 \mathrm{E}-01$ & $1.21 \mathrm{E}-01$ \\
\hline $\mathrm{NH}_{4}^{+}$ & 1143 & $6.72 \mathrm{E}-02$ & $\mathrm{NH}_{4}^{+}$ & 1180 & 6.94E-02 & 6.94E-02 \\
\hline $\mathrm{P}$ & 4.38 & $1.41 \mathrm{E}-04$ & & & & \\
\hline $\mathrm{S}$ & 465 & 1.45E-02 & & & & \\
\hline $\mathrm{Si}^{4+}$ & 37.9 & $1.35 \mathrm{E}-03$ & $\mathrm{Si}^{4+}$ & minimal & & \\
\hline $\mathrm{Ti}^{4+}$ & $<0.047$ & $<9.812 \mathrm{E}-07$ & $\mathrm{Ti}^{4+}$ & minimal & & \\
\hline $\mathrm{Zn}^{2+}$ & 4.8 & 7.34E-05 & $\mathrm{Zn}^{2+}$ & minimal & & \\
\hline $\mathrm{Zr}^{4+}$ & $<0.031$ & $<3.398 \mathrm{E}-07$ & $\mathrm{Zr}^{4+}$ & minimal & & \\
\hline $\mathrm{F}^{-}$ & 511 & 2.69E-02 & $\mathrm{F}^{-}$ & 559 & $2.94 \mathrm{E}-02$ & $-2.94 \mathrm{E}-02$ \\
\hline $\mathrm{Cl}^{-}$ & 1450 & 4.09E-02 & $\mathrm{Cl}^{-}$ & 1460 & $4.12 \mathrm{E}-02$ & $-4.12 \mathrm{E}-02$ \\
\hline $\mathrm{NO}_{2}^{-}$ & $<10$ & $<2.17 \mathrm{E}-04$ & $\mathrm{NO}_{2}^{-}$ & 6.3 & $1.37 \mathrm{E}-04$ & -1.37E-04 \\
\hline $\mathrm{NO}_{3}{ }^{-}$ & 5900 & $9.52 \mathrm{E}-02$ & $\mathrm{NO}_{3}^{-}$ & 5780 & $9.32 \mathrm{E}-02$ & $-9.32 \mathrm{E}-02$ \\
\hline $\mathrm{SO}_{4}{ }^{2-}$ & 1290 & $1.34 \mathrm{E}-02$ & $\mathrm{SO}_{4}{ }^{2-}$ & 1310 & $1.36 \mathrm{E}-02$ & $-2.73 E-02$ \\
\hline $\mathrm{PO}_{4}^{3-}$ & $<20$ & $<2.11 \mathrm{E}-04$ & $\mathrm{PO}_{4}^{3-}$ & 46 & 4.84E-04 & $-1.45 \mathrm{E}-03$ \\
\hline $\mathrm{CO}_{3}{ }^{2-}$ & 319 & 5.32E-03 & $\mathrm{CO}_{3}{ }^{2-}$ & minimal & & \\
\hline $\mathrm{pH}$ & 7.54 & & & & & \\
\hline cations & & & & & & $1.96 \mathrm{E}-01$ \\
\hline anions & & & & & & $1.94 \mathrm{E}-01$ \\
\hline
\end{tabular}

Yellow highlight = constituents added by dissolution of glass formers; blue highlight = major cations; green highlight = major anions; red highlight to emphasize Tc concentrations; and minimal =constituent very low predicted concentration because HTWOS does not consider dissolution of glass forming solids that get entrained in off-gas.

Although both off-gas simulants generated by the SRNL staff are within the range of compositions predicted by the HTWOS model, Nash et al. (2014) caution that HTWOS was not developed for the purpose of predicting the chemical composition of WTP waste streams. HTWOS is not a chemical thermodynamics- or kinetics-based computer code. Although useful, the HTWOS projected compositions should not be used for final design, regulatory, or safety-basis related calculations.Taylor-Pashow et al. (2015) used the direct feed off-gas simulant (shown in Table 5-8) to perform radionuclide removal studies using several sorbents: IE-95: UOP Ionsiv IE-95, 20×50 mesh (commercial zeolite); CST: Crystalline 
Silicotitanate, UOP Ionsiv IE-911 (commercial zeolite); MST $\left(\mathrm{NaTi}_{2} \mathrm{O}_{5} \cdot x \mathrm{H}_{2} \mathrm{O}\right): 15.6$ wt\% aqueous slurry; mMST: modified MST, 17.3 wt\% aqueous slurry; SrTreat obtained from Fortum Engineering Ltd., Finland; and ferric oxalate. For the DFLAW off-gas simulant that was adjusted to $\mathrm{pH} 12.3$ none of these sorbents were efficient at removing Tc. They did not use the $\mathrm{SnCl}_{2}$-hydroxy apatite that was effective, albeit at neutral $\mathrm{pH}$, for the WTP full operation off-gas simulant discussed in Section 5.1. There are only minor differences between the DFLAW and full operation WTP off-gas simulants shown in Table 5-8 and Table 5-6, respectively. Both are dominated by sodium and ammonium cations and nitrate, fluoride, chloride, and sulfate anions and have about 200 to $250 \mathrm{meq} / \mathrm{L}$ cations and anions.

\subsection{Comparison of Off-gas Simulants and Secondary Liquid Wastes Transferred to LERF/ETF}

Table 5-9 compares the measured compositions of the two, SRNL generated, off-gas simulants as well as the predicted compositions from the Excel spreadsheet for the volume-averaged LAW off-gas liquid waste streams discussed at the beginning of this section; except for the EMF concentrated waste stream sent back to DSTs. The two off-gas simulants created at SRNL are similar but the predicted chemical composition of the three off-gas waste streams from the One System: Tank Waste Disposition Integrated Flowsheet - River Protection Project Reference Integrated Flowsheet [see Arm et al. (2014, 2015)] vary widely. The chemical composition of the waste stream \#84b (EMF Bottoms Recycle) transferred from the EMF back to the LAW melter has a molar concentration dominated by sodium and nitrite; however the list of species tracked in Arm et al. $(2014,2015)$ are far smaller than the list that is available in the output ${ }^{14}$. From the SRNL reports it is clear that ammonium is a major component in the off-gas secondary waste liquids and ammonium predicted concentrations are not shown in the abbreviated list of elements tracked in Arm et al. $(2014,2015)$. It would appear that the \#84b interface waste composition shown in Arm et al. has been concentrated by some evaporation process while the DFLAW off-gas waste stream from Nash et al. (2014) has not been concentrated based on the fact that both predicted compositions represent off-gas liquid secondary wastes generated during the DFLAW phase of the WTP mission. The McCabe et al. (2013) and waste stream 41b from the Arm et al. $(2014,2015)$ reports show similar concentrations for the major constituents that are tracked in the Arm et al. reports. If the complete HTWOS outputs were available a more thorough comparison would be possible.

\footnotetext{
${ }^{14}$ The analytes tracked in Arm et al. $(2014,2015)$ are limited to key analytes. Key analytes were determined to those that significantly impact glass formulation, and oxalate, which was added to the list as an important analytes due to its impact on waste chemical stability, sludge washing and melter reduction/oxidation calculations. HTWOS tracks many more analytes and radionuclides but we have not obtained the detailed outputs from which the selected analytes were extracted and used in the Excel spreadsheet provided to us.
} 
Table 5-9. Comparison of SRNL Off-gas Simulants (Measured) versus HTWOS Predicted Tank Waste Disposition Integrated Flowsheet Off-gas Waste Streams

\begin{tabular}{|c|c|c|c|c|c|c|c|c|c|c|}
\hline \multirow[b]{2}{*}{ Component } & \multicolumn{2}{|c|}{ SRNL DFLAW off-gas } & \multicolumn{2}{|c|}{ SRNL PT off-gas } & \multicolumn{2}{|c|}{$35 b$} & \multicolumn{2}{|c|}{$41 \mathrm{~b}$} & \multicolumn{2}{|c|}{$84 \mathrm{~b}$} \\
\hline & ppm & $\mathrm{M}$ & $\mathrm{ppm}$ & $\mathrm{M}$ & Ppm & $\mathrm{M}$ & ppm & $\mathrm{M}$ & ppm & $\mathrm{M}$ \\
\hline $\mathrm{Al}$ & $<0.31$ & $<1.15 \mathrm{E}-04$ & $<0.1$ & $<3.70 \mathrm{E}-05$ & $2.70 \mathrm{E}+02$ & $1.00 \mathrm{E}-02$ & $1.17 \mathrm{E}+01$ & 4.32E-04 & $8.19 \mathrm{E}+01$ & 3.03E-03 \\
\hline $\mathrm{B}$ & 243 & $2.25 \mathrm{E}-02$ & 253 & $2.34 \mathrm{E}-02$ & NR & NR & NR & NR & NR & NR \\
\hline $\mathrm{Ca}^{2+}$ & 3.67 & $9.16 \mathrm{E}-05$ & $<0.1$ & $<2.50 \mathrm{E}-06$ & NR & NR & NR & NR & NR & NR \\
\hline $\mathrm{Cr}$ & 28.4 & $5.46 \mathrm{E}-04$ & 91 & $1.75 \mathrm{E}-03$ & $1.07 \mathrm{E}+01$ & 2.07E-04 & $3.49 \mathrm{E}+01$ & 6.72E-04 & $3.13 E+02$ & $6.02 \mathrm{E}-03$ \\
\hline $\mathrm{Fe}$ & $<0.07$ & $<1.3 \mathrm{E}-06$ & $<0.1$ & $<1.79 \mathrm{E}-06$ & $1.44 \mathrm{E}+02$ & $2.58 \mathrm{E}-03$ & $1.25 \mathrm{E}-01$ & $2.24 \mathrm{E}-06$ & 9.57E-01 & $1.71 \mathrm{E}-05$ \\
\hline $\mathrm{K}^{+}$ & 242 & $6.19 \mathrm{E}-03$ & 150 & 3.84E-03 & $2.43 E+00$ & $6.22 \mathrm{E}-05$ & $3.24 \mathrm{E}+01$ & $8.29 \mathrm{E}-04$ & $1.91 \mathrm{E}+03$ & 4.88E-02 \\
\hline $\mathrm{Li}^{+}$ & 72 & $1.04 \mathrm{E}-02$ & 80.3 & $1.16 \mathrm{E}-02$ & NR & NR & NR & NR & NR & NR \\
\hline $\mathrm{Mg}^{2+}$ & 1.01 & $4.15 \mathrm{E}-05$ & $<0.1$ & $<4.11 \mathrm{E}-06$ & NR & NR & NR & NR & NR & NR \\
\hline $\mathrm{Na}^{+}$ & 2660 & $1.16 \mathrm{E}-01$ & 2980 & $1.30 \mathrm{E}-01$ & $5.83 E+01$ & 2.53E-03 & $2.20 \mathrm{E}+03$ & $9.55 E-02$ & $4.41 \mathrm{E}+04$ & $1.92 \mathrm{E}+00$ \\
\hline $\mathrm{NH}_{4}^{+}$ & 1143 & $6.72 \mathrm{E}-02$ & 1773 & 1.04E-01 & NR & NR & NR & NR & NR & NR \\
\hline $\mathrm{P}$ & 4.38 & $1.41 \mathrm{E}-04$ & $<10$ & $<3.23 \mathrm{E}-04$ & NR & NR & NR & NR & NR & NR \\
\hline $\mathrm{S}$ & 465 & $1.45 \mathrm{E}-02$ & 832 & 2.59E-02 & NR & NR & NR & NR & NR & NR \\
\hline $\mathrm{Si}$ & 37.9 & $1.35 \mathrm{E}-03$ & 52.7 & $1.88 \mathrm{E}-03$ & NR & NR & NR & NR & NR & NR \\
\hline $\mathrm{Ti}$ & $<0.047$ & $<9.8 \mathrm{E}-07$ & $<0.1$ & $<2.09 \mathrm{E}-06$ & NR & NR & NR & NR & NR & NR \\
\hline $\mathrm{Zn}$ & 4.8 & 7.34E-05 & 28.6 & 4.38E-04 & NR & NR & NR & NR & NR & NR \\
\hline $\mathrm{Zr}$ & $<0.031$ & $<3.4 \mathrm{E}-07$ & $<0.1$ & $<1.10 \mathrm{E}-06$ & $3.44 \mathrm{E}+01$ & 3.58E-04 & NR & NR & NR & NR \\
\hline $\mathrm{F}^{-}$ & 511 & 2.69E-02 & 1250 & $6.58 \mathrm{E}-02$ & $2.32 \mathrm{E}+02$ & 1.22E-02 & $7.85 \mathrm{E}+02$ & 4.13E-02 & $3.47 \mathrm{E}+03$ & $1.83 \mathrm{E}-01$ \\
\hline $\mathrm{Cl}^{-}$ & 1450 & 4.09E-02 & 934 & 2.63E-02 & $1.84 \mathrm{E}+00$ & 5.19E-05 & $3.88 \mathrm{E}+02$ & 1.09E-02 & $1.73 E+04$ & $4.88 \mathrm{E}-01$ \\
\hline $\mathrm{NO}_{2}^{-}$ & $<10$ & $<2.17 \mathrm{E}-04$ & $<10$ & $<2.17 \mathrm{E}-04$ & $2.36 \mathrm{E}+02$ & 5.13E-03 & $1.82 \mathrm{E}+03$ & $3.95 E-02$ & $5.58 \mathrm{E}+04$ & $1.21 \mathrm{E}+00$ \\
\hline $\mathrm{NO}_{3}^{-}$ & 5900 & 9.52E-02 & 4900 & 7.90E-02 & $1.36 \mathrm{E}+01$ & 2.19E-04 & $8.60 \mathrm{E}+00$ & $1.39 \mathrm{E}-04$ & $7.61 \mathrm{E}+02$ & $1.23 \mathrm{E}-02$ \\
\hline $\mathrm{SO}_{4}{ }^{2-}$ & 1290 & $1.34 \mathrm{E}-02$ & 2410 & $2.51 \mathrm{E}-02$ & $4.47 \mathrm{E}+01$ & $4.66 \mathrm{E}-04$ & $8.65 \mathrm{E}+02$ & $9.01 \mathrm{E}-03$ & $1.40 \mathrm{E}+04$ & $1.46 \mathrm{E}-01$ \\
\hline $\mathrm{PO}_{4}^{3-}$ & $<20$ & $<2.11 \mathrm{E}-04$ & $<10$ & $<1.05 \mathrm{E}-04$ & 5.86E-01 & 6.17E-06 & $5.21 \mathrm{E}+01$ & 5.49E-04 & $3.92 \mathrm{E}+02$ & 4.13E-03 \\
\hline $\mathrm{CO}_{3}{ }^{2-}$ & 319 & 5.32E-03 & NR & NR & NR & NR & NR & NR & NR & NR \\
\hline $\mathrm{pH}$ & 7.54 & & 7.9 & & NR & NR & NR & NR & NR & NR \\
\hline & & $\mathrm{Eq}$ & & $\mathrm{Eq}$ & & $\mathrm{Eq}$ & & $\mathrm{Eq}$ & & $\mathrm{Eq}$ \\
\hline cations & & $2.71 \mathrm{E}-01$ & & 3.31E-01 & & 4.30E-02 & & $1.02 \mathrm{E}-01$ & & $2.01 \mathrm{E}+00$ \\
\hline anions & & 2.05E-01 & & 2.25E-01 & & $1.86 \mathrm{E}-02$ & & $1.12 \mathrm{E}-01$ & & $2.20 \mathrm{E}+00$ \\
\hline
\end{tabular}


None of the SRNL reports that describe the two off-gas simulants and studies that use the simulants to evaluate sorbents to remove radionuclides, such as ${ }^{99} \mathrm{Tc}$, contains information on the volume of off-gas condensates and flush-water liquid wastes that are produced. Robbins and May (2013) do give some information on the volume of off-gas secondary wastes produced

'Vitrification of low-activity waste (LAW) at the Hanford Waste Treatment and Immobilization Plant (WTP) generates a substantial volume (1.55M gallons per year) of secondary liquid wastes from the melter off-gas treatment system, submerged bed scrubber, and wet electrostatic precipitator (SBS/WESP).'

After converting this annual value to liters $\left(5.87 \times 10^{6} \mathrm{~L}\right)$ and comparing to the Arm et al. $(2014,2015)$ predicted volumes of secondary waste produced in each facility during each phase of WTP operation (see Table 5-4) for compositions of projected wastes for interfaces 35b and 41b) we can get an estimate of the years of operation that would be required if all the off-gas secondary waste was in fact from the melter off-gas systems referred to in Robbins and May (2013). Note that Arm et al. (2014, 2015) do not specify durations for each of their defined WTP mission phases so this exercise of comparing predicted total volumes of off-gas secondary liquid wastes captured and recycled back to the DSTs, or LAW melters with the cited annual off-gas secondary waste production rate is one form of a reality check. The result of this comparison is shown in Table 5-10. The estimated years of operation shown in Table 5-10 would likely be an over-estimation because all the secondary waste volumes predicted from the HTWOS computer run likely did not come exclusively from the off-gas systems that Robbins and May (2013) used to come up with their annual production rate. On the other hand if the vitrification operation does not run as efficiently as assumed by Robbins and May then the duration of each of the WTP operational Phases would be longer than these estimates shown in Table 5-10.

Table 5-10. Estimated Time In Yrs. of Operation for WTP Mission Phases Based on Robbins and May (2013) Estimate of the Annual Production of Off-gas Secondary Waste

\begin{tabular}{|l|c|c|c|c|c|c|c|}
\hline & Phase 1 & Phase 2 & Phase 3 & Phase 4a & Phase 4B & Phase 4C & $\begin{array}{c}\text { Total per } \\
\text { Stream }\end{array}$ \\
\hline \multicolumn{7}{|c|}{29 - returned to DSTs during DFLAW +84-b DFLAW EMF Bottoms to WTP LAW } \\
\hline Total Vol (L) & none & $1.98 \mathrm{E}+07$ & none & none & None & none & $1.98 \mathrm{E}+07$ \\
\hline Yrs. of Operation & NA & 3.37 & NA & NA & NA & NA & \\
\hline \multicolumn{7}{|c|}{$41 \mathrm{~b}-$ from LLW facility to WTP PT Facility } \\
\hline Total Vol (L) & none & none & $4.13 \mathrm{E}+07$ & $1.39 \mathrm{E}+08$ & $1.30 \mathrm{E}+08$ & $1.30 \mathrm{E}+08$ & $4.40 \mathrm{E}+08$ \\
\hline Yrs. of Operation & NA & NA & 7.04 & 23.68 & 22.15 & 22.15 & \\
\hline
\end{tabular}

This analysis suggests that the DFLAW (Phase 2) might last for at least 3.5 years, then Phase 3 might last for 7 years and Phase 4 would operate for up to 67 years.

A second estimate (Thien et al. 2015) of the volume of off-gas secondary liquid waste produced per day of operation for $2 \mathrm{LAW}$ melters is $2020 \mathrm{gal} / \mathrm{d}\left(2.79 \times 10^{6} \mathrm{~L} / \mathrm{yr}\right)$. This estimate is only $48 \%$ of the estimate found in Robbins and May (2013). So we caution the reader not to put much faith in the calculation of the duration of the WTP operation phases shown in Table 5-10. 


\subsection{Proposed Location of Tc Removal Facility from Off-gas Condensates and Flush Waters}

McCabe et al. (2013) describes an integrated plan to study several methods 1) to concentrate and/or 2) to remove radionuclides from off-gas condensates and WESP flush waters from the resultant secondary liquid wastes as alternatives to recycling this waste stream back ultimately to the LAW melters. As noted previously if this off-gas secondary waste stream could be processed so that it did not have to be recycled to the LAW melters there would be a considerable reduction in the number of glass canisters that need to be produced. This is because halides and sulfate concentrations build up in this recycle waste stream to levels that compromise LAW waste loading in the glass. The fluoride, sulfate, and chloride content in this recycled waste stream often limits the LAW glass waste loading, dictating generation of additional (up to a factor of $32 \%$ additional) glass canisters. Further, because the LAW vitrification is expected to commence before the PT facility is operational, there can be no recycle of this off-gas secondary waste stream in the early phases of the WTP mission, thus requiring some of it (after concentration/modification in EMF) to be sent back to DSTs, which have very limited unused volume.

One option that has been previously evaluated is disposal of the LAW Recycle stream directly to the ETF. However, this option has a number of problematical consequences to ETF including increases in waste volume, elevated (and perhaps unacceptable) halide and radionuclide levels [see Lueck and Mcnamar (2008) and May et al. (2009) for details]. Some of these consequences would be mitigated by first decontaminating the stream, as proposed by McCabe et al. (2013) as follows. The first activity in McCabe et al. (2013)'s plan is to concentrate the off-gas waste stream using either traditional evaporation (in an evaporator similar to 242-A) or reverse osmosis. Evaporation generally has the advantage of very high decontamination and concentration factors, but is energy intensive. Reverse osmosis has the advantage of compact equipment and minimal energy input, but with lower decontamination and concentration factors. The location for this proposed pre-concentration via evaporation or reverse osmosis is assumed to be in close proximity to the PT, likely in an adjoining building. The bottoms from the evaporator or concentrated brine from the reverse osmosis unit would be returned to DSTs or the PT (when operational) for recycle through the LAW melters. The condensate from the evaporator, or the permeate from the RO unit, would be sent to LERF and then on to ETF for final processing.

In the second alternative treatment process (McCabe et al. 2013), separation of the radionuclides would be done by precipitation or sorption using inorganic reagents followed by settling and/or filtration of the sorbents, similar to the SRS Actinide Removal Facility. For this proposed alternative treatment process, they assume that the radionuclide decontamination process occurs at the ETF after the recycled off-gas secondary waste stream is first segregated in one of the three 7.8-million gallon lined and covered LERF basins; although segregation of particular waste streams is not currently practiced. This segregated off-gas recycle waste stream would then be transferred into Secondary Waste Receiver Tanks (SWRT) in an ETF Secondary Treatment Train (STT), both to be added to an upgraded ETF. Within the STT would be a new evaporator that would concentrate the radionuclide decontaminated off-gas waste stream. The evaporator condensates would be sent to the existing ETF Primary Treatment Train (PTT) and the evaporator bottoms would be ultimately solidified into a final low-temperature waste form such as grout (see Figure 5-1). From the SWRT, the stream would be fed to the evaporator feed tank. Segregating the off-gas recycle waste and using the STT would enable receipt of the much higher ionic-strength recycle stream without impacting the PTT. It is assumed here that the evaporator bottoms will be immobilized in the yet-to-be-built solid treatment unit (STU), and disposed in the IDF. The evaporator condensate would be treated in the PTT at ETF, as current practice, to enable further decontamination and subsequent discharge through the State Approved Land Disposal Site (SALDS). 


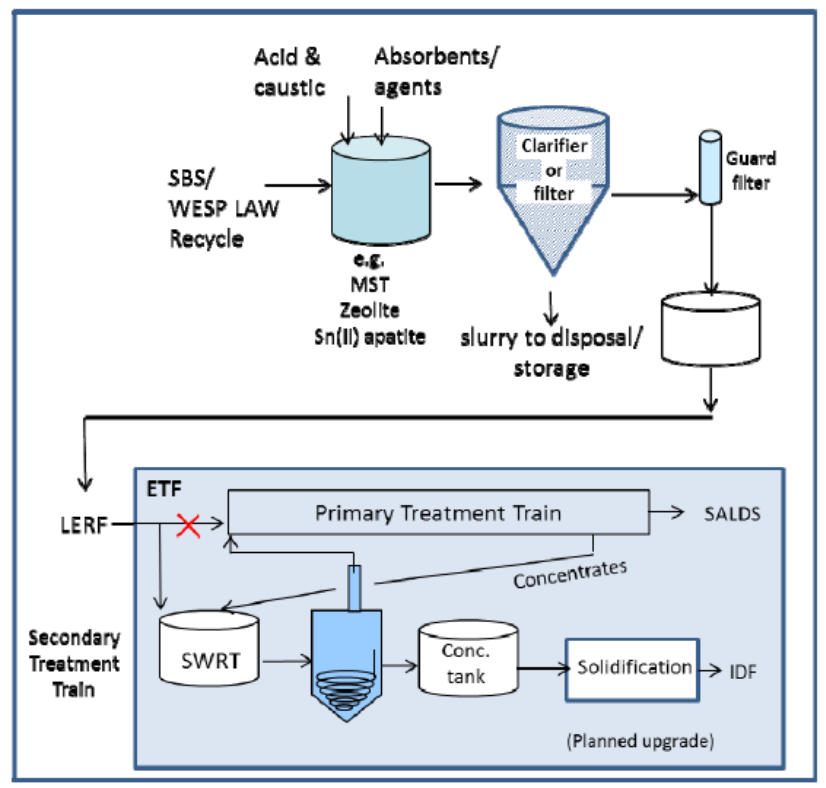

Figure 5-1. Schematic for Radionuclide Removal From Off-gas Secondary Waste from McCabe et al. (2013)

Although some Tc is present in the initial LAW stream as a soluble "non-pertechnetate” species [see Rapko et al. (2013a,b) and Serne et al. (2014)], the LAW melter is expected to convert "nonpertechnetate" chemical forms of Tc to the pertechnetate anion $\left(\mathrm{TcO}_{4}{ }^{-}\right)$with a +7 technetium oxidation state. Thus, the Tc expected in the LAW melter recycle waste streams should be $\mathrm{TcO}_{4}{ }^{-}$. Since the primary adsorbents and precipitating agents under investigation are inorganic, they should be compatible with the widest range of disposal options. These precipitation agents and adsorbents can also be evaluated for mixing as a slurry with the tank waste sludges, since inorganic materials can be accommodated more easily than organic materials in the tank farms, if interim storage is needed. The primary removal process investigated for technetium removal by McCabe et al.'s proposed Tc removal scheme will be reductive precipitation coupled with adsorption using $\mathrm{SnCl}_{2}$ and hydroxy apatite (see Taylor-Pashow et al. 2014a). If this Tc removal method proves to be unsuccessful, a number of organic ion exchange media (e.g., Reillex HPQ or Purolite A530E) could be evaluated (see Section 6 for more discussion). Disposal of the resultant adsorbent/precipitate from the radionuclide removal process is currently undefined in the plan set forth by McCabe et al. (2013). They first will attempt to quantify the amount and composition of slurry solids generated by the candidate radionuclide removal processes. Then such information will be used in the future to determine the compatibility with the various disposal options.

Robbins and May (2013) also evaluated similar options for diverting the off-gas secondary liquid waste stream from recycling back to the LAW melters. Their study only looked at SBS/WESP condensate from the LAW facility and does not include the HLW SBS/WESP. However, as mentioned the ${ }^{99}$ Tc inventory in the HLW melter off-gas waste stream (interface 35b) is insignificant (3.7 Ci; see Table 5-5). In their analysis they assumed that the Tc depleted stream could be processed at a modified Effluent Treatment Facility (ETF). For each alternative, the approach would be to pump the condensate from the LAW melter condensate collection tanks to a new Technetium Removal Facility (TRF) located outside of the WTP facility boundary but within the Hanford Site. They opine that it may be possible to combine the TRF processing facility into other proposed facilities. The modifications to the LAW Facility are the same for all their alternatives. Evaporative condensate from the TRF is transported to the ETF for final treatment and disposal. 
The Robbins and May (2013) alternatives are succinctly described as:

Alternative 1, “Technetium Removal with Solidification” - Removes technetium using elutable IX, concentrates it by evaporation, and solidifies it for disposal off site as a less than class A waste (Alternative $1 \mathrm{a}$ ) or a less than class $\mathrm{C}$ waste (Alternative $1 \mathrm{~b}$ ).

Alternative 2, “Technetium Removal with Precipitation” - Removes technetium by precipitation on a non-elutable IX media and drying the media for disposal off-site.

Alternative 3, “Technetium Removal with Vitrification” - Removes technetium using elutable IX, concentrates it by evaporation, and stabilizes it by vitrification in a stand-alone melter with improved Tc retention. 


\subsection{Review of Options for Purification/Pre-concentration of Tc from the SuperLig 639 Eluate and the Off-gas Condensate}

Several methods have been developed for separating Tc from alkaline radioactive waste solutions; these methods have been reviewed in several reports (representative reports include Brown et al. 2014; McCabe et al. 2012; Duncan et al. 2012; Duncan et al. 2011; and references therein). This section gives only a brief overview of the existing technologies relevant to the removal of Tc from the SuperLig 639 eluate and off-gas condensate, readers are referred to the original reports for more detailed discussion.

\subsection{Option 1: Separation of Tc by Ion Exchange}

Many different ion exchange separation technologies have been studied for pertechnetate removal from aqueous solutions and some of these are summarized in Table 6-1. A large portion of the literature discusses resin-based technologies such as Reillex, Dowex ${ }^{\circledR}$, and Purolite ${ }^{\circledR}$ resins. In most cases, more than one option is available from each vendor with slight differences in performance under different conditions. For example, multiple Dowex (e.g., SBR, 1X8, 2X8), Purolite (e.g., A-520E, A-530E, A532E), and Reillex (402, HP, HPQ) resins are discussed and compared throughout the literature although often under different conditions (Duncan et al. 2011). The costs of various resins vary widely from $\sim$ 13/kg (Purolite A530E) to \$410/kg (Dowex 1-X8) to \$500/kg (Reillex HPQ) although these costs are likely subject to change with quantities over time and it is difficult to compare them when some sorbents are only single-use whereas others are reusable up to a few hundred times. Some resins can be regenerated while others cannot.

Table 6-1. Summary of Tc-capture Options (Duncan et al. 2011). Data for specific types of a sorbent are listed in parenthesis if applicable.

\begin{tabular}{|c|c|c|c|}
\hline Option & Usage & Implementation details & Capacity \\
\hline ABEC & Reusable $(\sim 20 \times)$ & & $0.8 \mathrm{eq} / \mathrm{L}(2000)$ \\
\hline Reillex HPQ & Reusable $^{\text {a) }}$ & $\begin{array}{l}\text { SuperLig } 639 \text { eluate or } \\
\text { Off-gas }\end{array}$ & 4 eq/kg, dry (HPQ) \\
\hline Dowex & Reusable $^{\text {a) }}$ & $\begin{array}{l}\text { SuperLig } 639 \text { eluate or } \\
\text { Off-gas }\end{array}$ & $1.2 \mathrm{eq} / \mathrm{L}(1-\mathrm{X} 8)$ \\
\hline $\begin{array}{l}\text { Purolite A530 E } \\
\text { and A532E }\end{array}$ & Reusable ${ }^{a-b)}$ & $\begin{array}{l}\text { SuperLig } 639 \text { eluate or } \\
\text { Off-gas }\end{array}$ & $\begin{array}{l}0.9 \mathrm{eq} / \mathrm{L}(\mathrm{A} 520 \mathrm{E}) \\
0.6 \mathrm{eq} / \mathrm{L}(\mathrm{A} 530 \mathrm{E})\end{array}$ \\
\hline Sn-apatite & Single-use & $\begin{array}{l}\text { SuperLig } 639 \text { eluate or } \\
\text { Off-gas }\end{array}$ & $\begin{array}{l}\text { 2.25-2.50 eq/L (Kurion, } \\
\text { Inc.) }\end{array}$ \\
\hline $\mathrm{SnCl}_{2}$ & Single-use & $\begin{array}{l}\text { SuperLig } 639 \text { eluate or } \\
\text { Off-gas }\end{array}$ & \\
\hline Mineral $^{(\mathrm{c})}$ & Single-use & $\begin{array}{l}\text { SuperLig } 639 \text { eluate or } \\
\text { Off-gas }\end{array}$ & \\
\hline Powdered Fe $^{0}$ & Single-use & $\begin{array}{l}\text { SuperLig } 639 \text { eluate or } \\
\text { Off-gas }\end{array}$ & \\
\hline
\end{tabular}

a) Typically considered non-elutable, however can be regenerated using reductive stripping

b) Can be potentially regenerated by non-reductive process

c) Tc solid (spinel, ferric oxide, sodalite). 


\subsubsection{Reillex HPQ Resin}

The Reillex HPQ Polymer is a cross-linked poly-4-vinylpyridine macroporous polymer manufactured by Vertellus Specialties, Inc. (Indianapolis, IN). It is a strong base polymer (quaternary version of Reillex HP Polymer) finding use in the removal and purification of anionic materials (Reillex HPQ, 2015). This resin can be potentially used for Tc concentration both SuperLig 639 eluate and off-gas (Duncan et al. 2011) streams, however testing is required to evalaute the effect of competing anions and $\mathrm{pH}^{-} \mathrm{TcO}_{4}{ }^{-}$ retention.

Reillex HPQ has been demonstrated to remove $\mathrm{TcO}_{4}{ }^{-}$from simulated Hanford DST waste (Ashley et al. 1995, 1999; Blanchard et al. 1996, 1997). Ashley et al measured the following percent break though (BT) as a function of bulk volumes (BV) of the resin bed: $1 \% \mathrm{BT}$ at $27.9 \mathrm{BV}, 50 \% \mathrm{BT}$ at $95.9 \mathrm{BV}$, and $90 \% \mathrm{BT}$ at $145.7 \mathrm{BV}$ for DST supernate solution. Ashley eluted $\mathrm{TcO}_{4}{ }^{-}$off the Reillex HPQ column with a reductive $1 \mathrm{M} \mathrm{NaOH} / 1 \mathrm{M}$ ethylenediamine / $0.005 \mathrm{M} \mathrm{SnCl}_{2}$ solution in the opposite direction of loading. Reductive elution removed an average of $97 \%$ of the $\mathrm{TcO}_{4}{ }^{-}$off the resins loaded up to $50 \% \mathrm{BT}$. For the resin loaded to $90 \% \mathrm{BT}$, the Tc removal was reduced to $70 \%$. The Ashley et al. stripping method purportedly results in Tc(IV) species. However, more study is needed to resolve what Tc species is present in the resulting solution from this Reillex reductive stripping reaction. From this Reillex HPQ column eluate, one could either attempt to react the $\mathrm{TcO}_{4}{ }^{-}$with sodalite precursors and precipitate out sodalite or one could dry the eluate down to $\mathrm{NaTcO}_{4}$ powder and react the powder with sodalite precursors to ultimately produce sodalite.

Poineau et al. (2008) eluted $\mathrm{TcO}_{4}{ }^{-}$off the Reillex HPQ column using $1 \mathrm{M} \mathrm{NH}_{4} \mathrm{OH}$, recovering 94\% from the column. They then converted the eluted $\mathrm{TcO}_{4}{ }^{-}$to Tc metal using a three step process: 1) drying the $1 \mathrm{M} \mathrm{NH}_{4} \mathrm{OH}$ solution to a powder, 2) dissolution of the powder in water followed by precipitation of $\mathrm{TcO}_{4}{ }^{-}$as $\left(\mathrm{n}-\mathrm{Bu}_{4} \mathrm{~N}\right) \mathrm{TcO}_{4}$, and 3) conversion to Tc metal by pyrolysis and steam reforming under wet argon at $800^{\circ} \mathrm{C}$. The benefit of this approach is a clean Tc stream that can be reduced to Tc metal and then added with stainless steel to produce the stainless steel based alloy Tc waste form.

\subsubsection{Purolite A532E Resins}

Purolite A532E (Purolite Corporation, Bala Cynwyd, PA) is a resin with bi-functional quaternary amine functional groups that has a high selectivity for hydrophobic anions, e.g., $\mathrm{TcO}_{4}{ }^{-}$or $\mathrm{ClO}_{4}{ }^{-}$(Purolite A532E, 2015). It is manufactured under license from Oak Ridge National Laboratory. It comes as spherical beads of gel polystyrene cross-linked with divinylbenzene. The method for its elution has been developed (Brown et al. 2002; Gu et al. 2001) using aqueous or mixed water/methanol solutions of $\mathrm{FeCl}_{3}$ in presence of $\mathrm{HCl}$, (e.g., $1 \mathrm{M} \mathrm{FeCl}_{3}$ in $4 \mathrm{M} \mathrm{HCl}$ ). The complex $\mathrm{FeCl}_{4}{ }^{-}$anion has high affinity for the resin functional groups. Elution of perchlorate has been demonstrated using this method. Based on the structural similarity between $\mathrm{TcO}_{4}{ }^{-}$and $\mathrm{ClO}_{4}{ }^{-}$anions it is anticipated that the $\mathrm{FeCl}_{4}{ }^{-}$solution can also be applied for the elution of $\mathrm{TcO}_{4}{ }^{-}$from Purolite A532E regeneration. The Tc-laden eluate could be used directly to form sodalite or the Tc could be potentially reduced to metallic $\mathrm{Tc}(0)$ for incorporating into a metal alloy waste form.

\subsubsection{Dowex ${ }^{\mathrm{TM}}$ Effluent}

The Dowex ${ }^{\mathrm{TM}}$ SBR LC NG $(\mathrm{OH})$ is a high capacity strong base anion exchange resin in the hydroxide form that has been used to capture $\mathrm{TcO}_{4}{ }^{-}$from various liquid waste streams. This sorbent is referred to as Dowex "SRB-OH" throughout the literature. It is present within a styrene-divinylbenzene (gel). Alternatively, the Dowex 1-X8 resin in the chloride form is often used to capture $\mathrm{TcO}_{4}{ }^{-}$and is discussed 
by Duncan et al. (2011). The Dowex 1-X8 resin is operable in the full $\mathrm{pH}$ range of 0-14 and the resin can be eluted using $4 \mathrm{M} \mathrm{HNO}_{3}$ (15 BV) or $1 \mathrm{M} \mathrm{NaOH} / 1 \mathrm{M}$ ethylendiamine/0.005 $\mathrm{M} \mathrm{SnCl}_{2}$ solution ( 15 BV).

\subsection{Option 2: Separation of Tc By Reductive Precipitation}

\subsubsection{Tin(II) Precipitation}

Duncan et al. (2012) studied Sn(II) apatite to capture and immobilize soluble pertechnetate from dilute AN-105 Hanford DST simulated waste. The $\mathrm{TcO}_{4}{ }^{-}$appears to substitute for $\mathrm{PO}_{4}{ }^{3-}$ in the apatite structure based on fact that as Tc is removed from solution; $\mathrm{PO}_{4}{ }^{3-}$ appears in solution in equal molar amounts to the amount of $\mathrm{TcO}_{4}{ }^{-}$removed. However, there is no direct evidence that $\mathrm{TcO}_{4}{ }^{-}$replaces $\mathrm{PO}_{4}{ }^{3-}$ or another element in the apatite structure. The exact composition of the apatite is not presented but it is in the form of $\mathrm{Ca}_{x} \mathrm{Sn}_{10-x}\left(\mathrm{PO}_{4}\right)_{6}(\mathrm{OH})_{2}$ where $x$ varies based on the preparation process and changes upon introduction of $\mathrm{TcO}_{4}{ }^{-}$into the solution. The redox couple that occurs upon introduction of the $\mathrm{TcO}_{4}{ }^{-}$is with the $\mathrm{Sn}^{2+}$ and is presented below.

$$
\begin{aligned}
& 3 \mathrm{Sn}^{2+} \rightarrow 6 \mathrm{e}^{-}+3 \mathrm{Sn}^{4+} \\
& 2 \mathrm{Tc}^{7+}+6 \mathrm{e}^{-} \rightarrow 2 \mathrm{Tc}^{4+}
\end{aligned}
$$

The Sn-apatite is a high surface material that would require further treatment to consolidate it into a monolithic waste form. Further, Taylor-Pashow (2014a) found that a mixture of $\mathrm{SnCl}_{2}$ and hydroxyapatite removed $\mathrm{TcO}_{4}{ }^{-}$effectively from off-gas liquid secondary waste simulant only at neutral $\mathrm{pH}$. This Sn(II) reducing agent coupled with hydroxyapatite sorbent process was very effective at neutral $\mathrm{pH}$; removing essentially all of the Tc (to below a method detection limit of $5 \mu \mathrm{g} / \mathrm{L}$ ) within 2 hours. This was equivalent to a Tc Decontamination Factor (DF) $>577$. It was less effective when the off-gas simulant was adjusted to an alkaline $\mathrm{pH}=12$; where the $\mathrm{DF}$ for $\mathrm{Tc}$ was reduced to 3.4 to 3.6. It was also observed that the chromium in the off-gas liquid secondary waste simulant co-precipitates with the ${ }^{99} \mathrm{Tc}$ during the $\mathrm{SnCl}_{2}$ reduction. As shown in Table 5-9 most projected off-gas liquid wastes contain significantly greater masses of chromate compared to $\mathrm{TcO}_{4}{ }^{-}$such that enough $\mathrm{Sn}$ (II) reductant will need to be added to reduce both chromate and pertechnetate.

We have recently prepared $\mathrm{Sn}(\mathrm{II})$-Al(III)-phosphate material effective for the uptake and reduction of $\mathrm{TcO}_{4}{ }^{-}$from aqueous solutions with a wide range of ionic strength and $\mathrm{pH}$ (7 to highly alkaline) (Chatterjee et al. 2015). Similarly to $\mathrm{Sn}(\mathrm{II}) \mathrm{Cl}_{2}$ or $\mathrm{Sn}(\mathrm{II})$ apatite, Sn(II)-Al(III)-phosphate powder also reduces chromate, however to a lesser extent due to modification of the redox potential of Sn(II) upon its incorporation in the Al-phosphate framework.

The Sn(II)-based methods of removing $\mathrm{TcO}_{4}{ }^{-}$appear to be applicable to either the SuperLig 639 eluate or the melter off-gas liquid secondary waste solution. While testing the removal of $\mathrm{TcO}_{4}{ }^{-}$from offgas liquid waste simulants is currently being studied using $\mathrm{Sn}(\mathrm{II})$-based agents, their efficiency for the $\mathrm{TcO}_{4}{ }^{-}$removal from the SuperLig 639 eluate has not been demonstrated yet.

\subsubsection{Powdered Iron Column}

Iron metal $\left(\mathrm{Fe}^{0}\right)$ powder has been demonstrated to precipitate Tc from solution. In this approach, Delcul and Bostick (1995) used a column packed with powdered $\mathrm{Fe}^{0}$ and flowed a solution containing $\mathrm{TcO}_{4}{ }^{-}$through the column. The suggested removal mechanism is a reduction of the soluble $\mathrm{Tc}(\mathrm{VII})$ to the insoluble Tc(IV) oxyhydroxide. Strong oxidants such as Cr(VI) are expected compete with Tc(VII). It 
was also observed that pure forms of zero-valent iron are relatively ineffective toward pertechnetate removal. Rather, “dirty” zero-valent iron that contains some oxidized iron oxide present on its surface improves dramatically Tc(VII) removal. The small amounts of surface iron oxides appear to serve as nucleation sites for the deposition of polymeric Tc(IV) oxyhydroxide precipitates.

The $\mathrm{Fe}^{0}$ column eventually plugs when enough $\mathrm{Fe}^{0}$ converts to $\mathrm{Fe}_{2} \mathrm{O}_{3}$. The $\mathrm{Fe}^{0}$ is very inexpensive, especially compared to some of the Tc-specific ion exchange resins discussed in Section 6.1. The Tcloading with the $\mathrm{Fe}^{0}$ column approach is about 5 times higher than Reillex HPQ at $1.5 \mathrm{M} \mathrm{NaNO}_{3}$ at $\mathrm{pH}$ 8.5 (Delcul and Bostick 1995). Also, this approach could be an effective precursor to making the Tcladen metal alloy waste form where the product of this process could be heated under a reducing atmosphere to create a Tc(0)-containing metal alloy. One aspect to this approach that has not been investigated is to look at different particle sizes of $\mathrm{Fe}^{0}$ to see if the reactivity could be optimized. Applicability of this $\mathrm{Fe}^{0}$ column technology for the purification/concentration of Tc from both the SuperLig 639 eluate and off-gas liquid waste stream should be evaluated. 


\subsection{Immobilization of Purified Pre-concentrated Tc in Specific Waste Forms}

One of the most important aspects of the safe disposal of separated Tc is the strategy taken to immobilize the Tc in a specific, Tc separated waste form. In all waste form concepts, the primary goal is to maximize the loading of Tc in the waste form to limit the volume of total waste, while at the same time minimizing any loss of Tc during the production of the Tc-specific waste form due to volatility. This avoids additional work to recover any Tc that is lost and then recycle it back during a subsequent processing step. Four different categories of immobilization media were identified as being potential waste form matrices for the safe disposal of separated Tc and these include: mineral options, metal alloys, cementitious forms, and glass (Westsik et al. 2014). In our report only Tc-specific waste forms are briefly discussed.

In recent reviews by Luksic et al. (2015) and Westsik et al. (2014), some of which is discussed here, several different materials were discussed that have either been demonstrated to contain Tc in various forms (e.g., $\mathrm{Tc}^{0}, \mathrm{Tc}^{4+}, \mathrm{Tc}^{7+}$ ), or could potentially contain Tc based on data in the literature for species similar to Tc.

\subsection{Mineral Waste Form Options}

The mineral options where $\mathrm{TcO}_{2}$ has been or could be potentially incorporated include (but are not limited to) spinel (e.g., $\mathrm{Ni}_{2} \mathrm{TcO}_{4}$ ) (den Exter et al. 2006), rutile (e.g., $\mathrm{Ti}_{0.6} \mathrm{Tc}_{0.4} \mathrm{O}_{2}$ ) (Muller et al. 1964), pyrochlore (e.g., $\mathrm{Cd}_{2} \mathrm{Tc}_{2} \mathrm{O}_{7}$ ) (Hartmann et al. 2011; Hartmann et al. 2012), and perovskite (e.g., $\mathrm{CaTcO}_{3}$ ) (Hartmann et al. 2012). For dissolved $\mathrm{TcO}_{4}{ }^{-}$, the mineral options include sodalite [i.e., $\mathrm{Na}_{8}\left(\mathrm{AlSiO}_{4}\right)_{6}\left(\mathrm{TcO}_{4}\right)_{2}$ ] (Missimer and Rutherford 2013), goethite [i.e., (Fe,Tc)O(OH)] (Um et al. 2011; Um et al. 2010), and layered double hydroxides (e.g., KMS-2) (Alliot Llorens et al. 2008; Kang et al. 1996; Qafoku et al. 2014). A summary of a few parameters from these materials is presented in Table 7-1.

For all of the mineral options, the Tc-containing product would likely not make a viable waste form without further processing due to the small particle size and high surface area associated with the products. Once produced, the subsequent processing options to produce a final monolithic form for disposal include the following:

1) The product could be pressed and sintered to form a monolith. This could leave undesirable residual porosity not fully removed during sintering in the fired product.

2) The mineral waste product could be mixed with a chemically durable binder such as a glass and then pressed and fired. The glass binder could help fill the void space in the monolithic product to help increase both mechanical rigidity and chemical durability of the consolidated product but at the "cost" of lowering the Tc mass loading in the final product. 
Table 7-1. Summary of Demonstrated Tc-Loadings in Various Minerals. The theoretical Tc-loading depends on the constituents used to make the particular mineral and, in most cases, several compositions are possible. Note that none of these have been demonstrated on a large scale.

\begin{tabular}{|c|c|c|c|c|c|c|}
\hline \multirow{2}{*}{$\begin{array}{c}\text { Mineral } \\
\text { Option }\end{array}$} & \multirow[t]{2}{*}{ Chemical Formula } & \multicolumn{2}{|c|}{ Tc-loading (mass\%) } & \multirow{2}{*}{$\begin{array}{c}\text { Tc } \\
\text { Form }\end{array}$} & \multirow[t]{2}{*}{ Reference(s) } & \multirow[t]{2}{*}{ Comments } \\
\hline & & Demonstrated & Theoretical & & & \\
\hline $\begin{array}{l}\text { Layered } \\
\text { double } \\
\text { hydroxide }\end{array}$ & $\mathrm{Mg}_{6} \mathrm{Al}_{2}(\mathrm{OH})_{17} \mathrm{TcO}_{4}$ & 14.9 & unknown & $\mathrm{TcO}_{4}^{-}$ & Kang et al. (1996) & $\begin{array}{l}\text { Layered double hydroxides are not ion } \\
\text { selective for } \mathrm{TcO}_{4}^{-} \text {and will likely } \\
\text { incorporate many of the secondary ions } \\
\text { present }\end{array}$ \\
\hline Sodalite & $\mathrm{Na}_{8}\left(\mathrm{AlSiO}_{4}\right)_{6}\left(\mathrm{TcO}_{4}\right)_{2}$ & 1.1 & 15.9 & $\mathrm{TcO}_{4}^{-}$ & $\begin{array}{l}\text { Mattigod et al. (2006); Missimer } \\
\text { and Rutherford (2013) }\end{array}$ & $\mathrm{OH}^{-}$will compete with sodalite cage sites \\
\hline Pyrochlore & $\mathrm{Cd}_{2} \mathrm{Tc}_{2} \mathrm{O}_{7}$ & 36.5 & 36.5 & $\begin{array}{l}\mathrm{TcO}_{2} \text { or } \\
\mathrm{Tc}_{2} \mathrm{O}_{7}\end{array}$ & $\begin{array}{l}\text { Hartmann et al. (2011); } \\
\text { Rodriguez (2009) }\end{array}$ & Typically small particle sizes \\
\hline Spinel & $\mathrm{Mg}_{2} \mathrm{TcO}_{4}$ & 46.3 & 46.3 & $\mathrm{TcO}_{2}$ & Muller et al. (1964) & $\begin{array}{l}\text { Typically small particle sizes but can likely } \\
\text { be made up to } 10 \mu \mathrm{m}\end{array}$ \\
\hline Perovskite & $\mathrm{SrTcO}_{3}$ & 41.7 & 41.7 & $\mathrm{TcO}_{2}$ & $\begin{array}{l}\text { Muller et al. (1964); Rodriguez } \\
\text { (2009) }\end{array}$ & Typically small particle sizes \\
\hline Rutile & $\mathrm{Ti}_{0.6} \mathrm{Tc}_{0.4} \mathrm{O}_{2}$ & 39 & 39 & $\mathrm{TcO}_{2}$ & Muller et al. (1964) & Typically small particle sizes \\
\hline Goethite & $\mathrm{FeO}(\mathrm{OH})$ & 0.5 & unknown & $\mathrm{TcO}_{2}$ & $\begin{array}{l}\text { Um et al. (2011); Um et al. } \\
\text { (2010) }\end{array}$ & $\begin{array}{l}\text { Tc-loading is lowest in this waste form of } \\
\text { the listed options }\end{array}$ \\
\hline
\end{tabular}




\subsubsection{Sodalite}

Sodalite has the general formula $\mathrm{Na}_{8}\left(\mathrm{AlSiO}_{4}\right)_{6} \mathrm{X}_{2}$ where $\mathrm{X}=2$-, 1-, or 0 -valent species. The other constituents present in the sodalite can be changed as well. The general formula for Na-based $\mathrm{TcO}_{4}{ }^{-}$ containing sodalite is $\mathrm{Na}_{8}\left(\mathrm{AlSiO}_{4}\right)_{6}\left(\mathrm{TcO}_{4}\right)_{2}$. Several different methods can be used to fabricate sodalite and they include (1) high temperature structural conversion of zeolite (or other aluminosilicates) and salt into sodalite, (2) solution-based (wet chemical) processing at atmospheric pressure and room, or slightly elevated temperatures, (3) hydrothermal processing where reactants are mixed in water and heated at moderate temperatures $\left(T \geq 150^{\circ} \mathrm{C}\right)$ under pressure in an autoclave, and (4) sol-gel processing where polycondensation reactions result in an interlinked network surrounded by a solvent. To the authors' knowledge, the only approach that has been attempted to date for making a $\mathrm{TcO}_{4}{ }^{-}$or $\mathrm{ReO}_{4}{ }^{-}$-based sodalite has been a hydrothermal approach (Dickson et al. 2014; Mattigod et al. 2006; Missimer and Rutherford 2013).

In efforts to characterize steam bed reformers, $\mathrm{TcO}_{4}^{-}$- and $\mathrm{ReO}_{4}{ }^{-}$-bearing sodalite samples were synthesized by Missimer and Rutherford (2013). Here, $6 \mathrm{~g}$ of $\mathrm{NaReO}_{4}$ were combined with $0.6 \mathrm{~g}$ of zeolite $4 \mathrm{~A}$, water, and $\mathrm{NaOH}$ in a pressure vessel and heated to $225^{\circ} \mathrm{C}$ for $7 \mathrm{~d}$, at which time approximately $1.5 \mathrm{~g}$ of $\mathrm{ReO}_{4}{ }^{-}$-sodalite was collected by filtration. For pertechnetate sodalite, $\sim 0.33 \mathrm{~g}$ of the total $6 \mathrm{~g}$ of $\mathrm{NaReO}_{4}$ was replaced with $\mathrm{NaTcO}_{4}$, and the heat treatment was extended to $8 \mathrm{~d}$. The structures and presence of Tc in the perrhennate/pertechnetate sodalite were confirmed by $\mathrm{x}$-ray diffraction (XRD) and scanning electron spectroscopy with energy dispersive spectroscopy (SEM-EDS).

Mattigod et al. (2006) produced $\mathrm{ReO}_{4}{ }^{-}$-sodalite through hydrothermal processing at $175^{\circ} \mathrm{C}$ for $1 \mathrm{~d}$. For this process, $40.98 \mathrm{~g}$ of $\mathrm{NaReO}_{4}$ was dissolved in $30 \mathrm{~mL}$ of deionized distilled water. Next, $9.0 \mathrm{~g}$ of $\mathrm{NaOH}$ was added to the $\mathrm{NaReO}_{4}$ solution and mixed until dissolution was complete. To this solution, $0.82 \mathrm{~g}$ of $\mathrm{NaAlO}_{2}$ solid was added, and the solution was brought up to $35 \mathrm{~mL}$. A second solution was prepared that contained $2.842 \mathrm{~g}$ of $\mathrm{Na}_{2} \mathrm{SiO}_{3}$ in $15 \mathrm{~mL}$ of deionized distilled water. The $\mathrm{Na}_{2} \mathrm{SiO}_{3}$ solution was stirred into the first solution containing $\mathrm{NaReO}_{4}, \mathrm{NaOH}$, and $\mathrm{NaAlO}_{2}$. This mixture containing $4.5 \mathrm{M}$ $\mathrm{NaOH}, 0.5 \mathrm{M} \mathrm{NaAlO}_{2}, 0.5 \mathrm{M} \mathrm{Na}_{2} \mathrm{SiO}_{3} \cdot 9 \mathrm{H}_{2} \mathrm{O}$, and $3 \mathrm{M} \mathrm{NaReO}_{4}$, was transferred to a $125 \mathrm{~mL}$, Teflon-lined Parr reactor and allowed to react for $24 \mathrm{~h}$ at $175^{\circ} \mathrm{C}$. The resulting white crystalline powder was thoroughly washed to remove salts and dried for $24 \mathrm{~h}$ at $70^{\circ} \mathrm{C}$. The dry product yield of $\mathrm{Na}_{8}\left(\mathrm{AlSiO}_{4}\right)_{6}\left(\mathrm{ReO}_{4}\right)_{2}$ was $3.2 \mathrm{~g}$.

Additionally, there is potential to convert directly $\mathrm{LAW}$, containing the $\mathrm{TcO}_{4}{ }^{-}$, into ceramic waste forms including a mixture of minerals that incorporate a variety of different anions, e.g., sodalite $\left(\mathrm{Cl}^{-}, \mathrm{I}^{-}\right)$, cancrinite $\left(\mathrm{NO}_{3}{ }^{-}, \mathrm{NO}_{2}{ }^{-}\right)$, nosean $\left(\mathrm{SO}_{4}{ }^{2-}\right)$, and hauyne $\left(\mathrm{SO}_{4}{ }^{2-}, \mathrm{Cl}^{-}, \mathrm{I}^{-}\right)$. The primary drawback with this approach is that the majority of the anions in LAW waste that are incorporated into the mixed mineral waste form are not radioactive, resulting in a volume of waste that is large compared to the generating a Tc-specific waste form from a Tc separated liquid waste stream. Stated differently, directly using LAW results in a larger volume of final waste form, with a lower Tc loading, because of competition of the other anions in LAW for the ceramic minerals' structural sites that can accommodate Tc.

Additionally, the fluidized bed steam reforming (FBSR) process is a technique for immobilizing Tc, most likely in the sodalite mineral within the FBSR suite of minerals as was summarized by Westsik et al. (2014) and Jantzen et al. (2014). While a large amount of tests evaluating the FBSR approach have been done with rhenium simulants (Pierce et al. 2014; Neeway et al. 2014b), a few have used actual Tc (Jantzen et al. 2013). In the FBSR process, the various waste components (e.g., Tc, Cs) get encapsulated in mineral forms such as nepheline $\left(\mathrm{NaAlSiO}_{4}\right)$, nosean $\left[\mathrm{Na}_{8}\left(\mathrm{AlSiO}_{4}\right)_{6}\left(\mathrm{SO}_{4}\right)\right]$, and sodalite 
$\left.\left[\mathrm{Na}_{8}(\mathrm{AlSiO})_{6}\right)_{6}\left(\mathrm{TcO}_{4}\right)_{2}\right]$, and then the product is placed in an encapsulating material such as a cement, geopolymer, or Ceramicrete (TTT, 2009). Both granular and monolithic forms have been evaluated as potential waste forms and they both pass chemical durability tests.

\subsubsection{Spinel}

Spinel is a mineral with a cubic space group that can take the form of $\mathrm{A}^{2+} \mathrm{B}_{2}^{3+} \mathrm{O}_{4}$ or $\mathrm{A}_{2}^{2+} \mathrm{B}^{4+} \mathrm{O}_{4}$ where $\mathrm{A}$ and $\mathrm{B}$ are of either octahedral or tetrahedral coordination. Spinel can be made using a variety of techniques including aqueous precipitation/co-precipitation (Chen et al. 1996; Laurent et al. 2008; Lukens et al. 2012), hydrothermal synthesis (Chen et al. 2003; Giannakopoulou et al. 2002; Sisk et al. 1995), and molten salt synthesis (Afanasiev and Geantet 1998; Geselbracht et al. 2004; Kimura 2011) to name a few of the more common techniques. The products from these different synthesis techniques range in size from nanometers to 10's of micrometers.

Spinel can be made with $\mathrm{TcO}_{2}$ where the $\mathrm{Tc}^{4+}$ can occupy the octahedral " $\mathrm{B}$ " site for the $\mathrm{A}_{2}^{2+} \mathrm{B}^{4+} \mathrm{O}_{4}$ spinel (Luksic et al. 2015). However, not all of the synthesis techniques available for making spinel have been demonstrated with $\mathrm{TcO}_{2}$ but the cited literature does show several promising options and potential flexibility for synthesizing this mineral. The technetium loading in spinel can be very high, such as in $\mathrm{Mg}_{2} \mathrm{TcO}_{4}$ spinel where the Tc-loading is 46 mass\% (Muller et al. 1964).

\subsubsection{Rutile}

The rutile $\left(\mathrm{TiO}_{2}\right)$ or stannic oxide $\left(\mathrm{SnO}_{2}\right)$ structures have been demonstrated to accommodate $\mathrm{TcO}_{2}$ in the structure. For rutile, it was in the form of $\mathrm{Ti}_{0.6} \mathrm{Tc}_{0.4} \mathrm{O}_{2}$ with a Tc-loading of 39 mass\% (Muller et al. 1964).

\subsubsection{Pyrochlore}

Pyrochlore fits the formula of $\mathrm{A}_{2} \mathrm{~B}_{2} \mathrm{O}_{6}$ or $\mathrm{A}_{2} \mathrm{~B}_{2} \mathrm{O}_{7}$ where $\mathrm{A}$ and $\mathrm{B}$ are metals of different valences. Pyrochlore can be synthesized using a number of different techniques including sintering, hydrothermal processing, and ball-milling. Pyrochlores have been synthesized from both $\mathrm{TcO}_{2}$ (Hartmann et al. 2012; Rodriguez 2009) and $\mathrm{Tc}_{2} \mathrm{O}_{7}$ (Rodriguez 2009) mixed with various $2+$ and $3+$ metal oxides. The Tc-containing pyrochlores synthesized with high Tc-loading, 37 mass\%, by Hartmann et al. (2012) had a very small particle size of $\sim 120 \mathrm{~nm}$, which could be problematic from a handling standpoint.

\subsubsection{Perovskite}

Perovskite fits the $\mathrm{A}^{2+} \mathrm{B}^{4+} \mathrm{O}_{3}$ formula where $\mathrm{A}$ and $\mathrm{B}$ are 2+ and 4+ cations, respectively. A majority of the literature discusses mixing $\mathrm{TcO}_{2}$ with other metal oxides and firing them together, a method typically referred to as high-temperature sintering. Also, $\mathrm{TcO}_{2}$ has been incorporated into perovskite materials using methods such as sol-gel synthesis (Huang et al. 1996), hydrothermal approaches (Sasaki et al. 1987), and milling (Baek et al. 1997).

\subsubsection{Goethite}

Goethite fits the formula of $\mathrm{AO}(\mathrm{OH})$ where $\mathrm{A}$ is one or a combination of different metals. The Fe-form of goethite, $\mathrm{FeO}(\mathrm{OH})$ has been demonstrated to incorporate Tc using aqueous precipitation. In one approach, $\mathrm{Fe}^{2+}$ was combined with $\mathrm{Tc}^{7+}$ in solution and the two species underwent a redox couple 
reaction (Um et al. 2011; Um et al., 2010). Afterwards, when $\mathrm{Fe}\left(\mathrm{NO}_{3}\right)_{3}$ was added to the solution with the Tc-containing goethite, a very small amount Tc was observed to re-oxidize from $\mathrm{Tc}^{4+}$ to $\mathrm{Tc}^{7+}$.

$$
\begin{gathered}
3 \mathrm{Fe}^{2+} \rightarrow 3 \mathrm{e}^{-}+3 \mathrm{Fe}^{3+} \\
\mathrm{Tc}^{7+}+3 \mathrm{e}^{-} \rightarrow \mathrm{Tc}^{4+}
\end{gathered}
$$

Detailed overview of this waste form can be found in Westsik et al. (2014 and references therein). Goethite could sequester significant amounts ( $>90 \%$ of the initial Tc mass) of Tc present in dilute solutions as long as additional aqueous $\mathrm{Fe}(\mathrm{II})$ was added and the $\mathrm{pH}$ of the slurry was adjusted to neutral to mildly caustic conditions. The Fe(II)-treated goethite also removed Tc from caustic briney waste solutions similar to Hanford off-gas secondary liquid wastes; however, the presence of anions other than hydroxide and carbonate in the waste streams, especially $\mathrm{PO}_{4}{ }^{3-}$ and, to a lesser extent $\mathrm{SO}_{4}{ }^{2-}$, decreases the Tc-removal efficiency. It was also discovered that after the mixing of the caustic waste simulants, with the goethite, and aqueous Fe(II), and separating the Tc-laden hydrous ferric oxide, there was a small amount of Tc re-release from the solid via Fe oxide dissolution at high $\mathrm{pH}$ conditions above 10 . Thus, the final disposal environment of the Tc-laden ferric oxide is optimal in subsurface environments with a $\mathrm{pH}$ below 10 or additional ferric iron should be added to keep the disposal saturated with dissolved iron.

Westsik et al. (2014) concluded that "more detailed experiments (both Tc sequestration and subsequent long term leaching) and solid-phase characterization studies using various state-of-the-art techniques are needed to evaluate the suitability of the goethite-based waste form. Note also that the final technetium-iron oxide minerals are fine-grained particles that would require some form of encapsulation, mixing with a binder, isostatic pressing into pellets, or disposal in high-integrity containers to be a nondispersible waste form.”

Reported Tc loading in goethite is $0.096 \mathrm{mg}$-Tc/g of final solid prepared with deionized water and $2.2 \times 10^{-5} \mathrm{M}$ of Tc and $1.02 \mathrm{mg}-\mathrm{Tc} / \mathrm{g}$ of final solid prepared with simulant containing $4.06 \times 10^{-4} \mathrm{~mole} / \mathrm{L}$ of Cr, $2 \mathrm{M} \mathrm{Na}$ and higher initial Tc concentration of $4.2 \times 10^{-4} \mathrm{M}$ of Tc and $0.1 \mathrm{M}$ of Fe(II) (Um et al. 2010). Tc loading on a Tc-goethite sample made from this waste simulant could be increased up to $5.02 \mathrm{mg}$ Tc/g (Um et al. 2015).

\subsubsection{Compatibility of Mineral Waste Forms with Tc Streams}

Based on the assessment of the Tc separation technologies from the SuperLig 639 eluate or off-gas condensate (see Section 6) only two streams are considered herein: the Reillex HPQ eluate and the Tc(IV) precipitate generated by the $\mathrm{Sn}(\mathrm{II}) \mathrm{Cl}_{2}$ reduction process. The Reillex HPQ strip can be conducted using a $1 \mathrm{M} \mathrm{NaOH} / 1 \mathrm{M}$ ethylenediamine/0.005 $\mathrm{M} \mathrm{SnCl}_{2}$ solution or a $1 \mathrm{M} \mathrm{NH}_{4} \mathrm{OH}$ solution, the former elution process purportedly results in Tc(IV) species and the latter results in pertechnetate being eluted. However, more study is needed to resolve what Tc species is present in the resulting solution from the Reillex stripping reactions. The $\mathrm{Sn}(\mathrm{II}) \mathrm{Cl}_{2}$ reductive precipitation approach results in a solid containing mixed valences of Sn(IV)/Sn(II) with a Tc(IV) co-precipitate (see Asmussen et al. (2016) for details. It is $\mathrm{Tc}(\mathrm{IV})$ that is required to make mineral structures including goethite, spinel, rutile, pyrochlore, and perovskite. The Tc(IV) could be re-oxidized to Tc(VII) to be incorporated into the other forms of sodalite or layered double hydroxides. For the $1 \mathrm{M} \mathrm{NH}_{4} \mathrm{OH}$ stripping solution (Poineau et al. 2008), pertechnetate is the species eluted, which is compatible for incorporation into sodalite. 


\subsection{Metal Alloy Waste Forms}

Two metal waste forms have been studied for immobilization of the five metal phase ( $\varepsilon$-phase; Mo, Tc, Rh, Rh, and Pd) from spent nuclear fuel. Those waste forms are $\varepsilon$-metal and 316 stainless steel (316SS) of which, Tc was the main isotope of concern (Abraham et al. 1997; Ebert et al. 2010; Ebert et al. 2009; Keiser Jr et al. 2000; McDeavitt et al. 1998). The $\varepsilon$-metal has a hexagonal close pack structure (P63) that accommodates a wide range of binary to quinary mixtures of the five noble metals. The $\varepsilon$-metal waste form appears to be very attractive because no additives are needed to fabricate the waste form (Crum et al. 2013). However, in the Tc separation schemes under discussion for the Hanford liquid wastes, only Tc would be present, resulting in the other four elements (Mo, Rh, Rh, and Pd) becoming expensive additives. Hence, because of cost, the 316SS-based waste form is the only practical metal alloy waste form for Hanford separated Tc. Besides the cost of additives, there are a few other advantages of selecting the 316SS alloy waste form: 1 ) the waste form development research is more mature for the SS based system, 2) the processing temperatures are significantly lower for SS-based waste forms, leading to lower energy costs and lower volatility of the reduced Tc during consolidation, and 3) the equipment to produce the SS-based waste form is simpler to operate and maintain.

The 316SS composition would be the preferred alloy composition however other alloy compositions could also be investigated to accommodate other waste components such as $\mathrm{Cr}$, which varies widely in concentration from Hanford tank to tank and the various WTP waste types. Depending on the Tc separations method to be used, components such as Fe, Sn, or Cr may be of significant concentration within the separated Tc waste causing a significant deviation from the desired 316SS composition (Keiser Jr et al. 2000; McDeavitt et al. 1998). Zirconium could also be varied to provide a $\mathrm{ZrFe}_{3}$ intermetallic phase that accommodates the Tc in the SS-based waste from (Keiser Jr et al. 2000).

It is difficult to state the maximum waste loading of Tc in metal alloy waste forms until a specific separations process is identified due to the variability is the resulting waste stream. However, assuming a clean Tc stream, the minimum waste loading in a metal alloy waste form would be 5 mass \% and could be as high as 20 mass \%. However, since the total amount of Tc that is in the tanks is small the waste loading in the metal alloy waste form should not have a drastic impact on amount of waste form produced. Research is needed to optimize the waste loading of a Tc only stream since all the literature to date is for the five noble metal alloy that exists in spent nuclear fuel. Research on a Tc-laden metal alloy waste form will provide data needed to determine the impact of Tc waste loading on final waste form performance. 


\subsection{Summary and Recommendations}

The current study is focused on conducting a literature review to provide insights into the compositions and volumes of the potential WTP waste streams, from which Tc could be separated effectively. The information obtained from this review is used to examine the compatibilities of these waste streams with Tc-specific waste forms and the operations required for Tc immobilization in the candidate Tc-specific waste forms.

One obvious advantage of the disposition of Tc in a specific waste form is the significant reduction in volume for the generated waste form, leading in turn to the reduction in the footprint of the required storage facility. If a Tc-specific separation process is found that pre-concentrates Tc that then can be readily loaded into a Tc-specific waste form, the total volume of Tc-bearing waste could be small.

The first logical location to remove Tc from WTP waste streams is from the tank waste after it is transferred to various "pre-treatment” facilities, likely after removal of ${ }^{137} \mathrm{Cs}$. The most mature method to remove the Tc from ${ }^{137} \mathrm{Cs}$-stripped tank waste is through the use of SuperLig 639. However effective removal of $\mathrm{TcO}_{4}{ }^{-}$by this resin requires concentration of sodium in the solution to be above $4 \mathrm{M}$. The Phase 2 DST waste going to the LAWPS facility may be too low in Na to be processed to remove $\mathrm{TcO}_{4}{ }^{-}$ using SuperLig 639 without adding additional $\mathrm{Na}$, or concentrating the solution by evaporation. Further, most of the final Phase 4C wastes have Na concentrations at or below $3.3 \mathrm{M}$, which may also require $\mathrm{Na}$ addition (or evaporation of the liquid wastes). Pertechnetate is eluted from SuperLig 639 with warm water. It is estimated that during the entire WTP campaign the total volume of Tc eluate will be between 18.7 and 25.5 million liters. Therefore, further concentration and purification of this SuperLig 639 Tc eluate may be required for the stabilization in a Tc-specific waste form.

A second location for the removal of Tc during DFLAW (Phase 2 of the WTP mission) is after LAW vitrification in the liquid wastes from EMF bottoms returns but before going back to DSTs or before EMF bottoms recycle to the LAW melters. If Tc was removed from these two waste streams it becomes possible to transfer the resultant liquid waste (with Tc removed) to the LERF/ETF facilities for a final processing that creates a solid waste form and a residual liquid. The residual liquid contains such low concentrations of contaminants that it can be disposed to ground without further treatment.

The HTWOS code predicts Na concentration of $4.91 \mathrm{M}$ in the EMF bottoms returns, similar to concentrations found in the DSTs where successful removal of Tc by SuperLig 639 has been demonstrated. The larger portion of EMF concentrated off-gas liquid waste, which is sent back to the LAW melters, is estimated to contain a Na concentration of up to $1.92 \mathrm{M}$. At this high ionic strength, the direct removal of Tc by traditional anion exchange resins might be challenging; however, use of SuperLig 639 should be realistic for the concentrated portion currently planned to recycle to the DSTs. SuperLig 639 could also be used after modest concentration of the EMF off-gas waste stream that currently is planned to be sent back to the LAW melters.

The HLW WTP facility returns 66.5 million liters of off-gas captured liquid waste to the WTP PT facility over Phases 3 and 4 . However, the Tc content in this waste stream is very low (2.75 Ci). The LLW WTP facility returns 440 million liters of off-gas captured liquid waste to the WTP PT facility over Phases 3 and 4 and the projected Tc content is substantial $(9270 \mathrm{Ci}$ ). The chemical composition of the LLW off-gas liquid waste stream is dominated by fluoride, chloride and sodium with a total ionic strength of about $0.128 \mathrm{M}$. It would make sense to separate Tc from this off-gas liquid waste stream within the WTP PT facility perhaps using standard ion exchange resins (discussed in Section 6.1) or some reducingsorbent process such as using Sn(II)-apatite (discussed in Section 6.2.1) or Fe(II)-ferric hydrous oxides 
(discussed in Section 7.1.6). Because the chromate anion, whose concentration is about 54 times greater than that of pertechnetate in LAW feed, is quite similar to the pertechnetate anion, it will act as a strong competitor for the pertechnetate anion exchange sites and also will be reduced if a reductant precipitation process is chosen to separate the Tc from the off-gas liquid waste streams as an alternative to recycling this stream back through LAW/SLAW melters. Thus, the consequences of the presence of chromate will need to be considered in any Tc separation scheme.

Since the primary adsorbents and precipitating agents under investigation are inorganic, they should be compatible with the widest range of disposal options based on the assumption that inorganic agents are more stable in underground disposal environments than organic agents, which can be degraded more readily by both biological and chemical processes. The inorganic agents under consideration can also be evaluated for mixing as slurry with the tank waste sludges, since inorganic materials can be accommodated more easily than organic materials in the tank farms, if interim storage is needed. A number of organic ion exchange media (e.g., Reillex HPQ or Purolite A530E) could also be evaluated to remove Tc from the more dilute off-gas captured WTP waste stream. The disposal of the adsorbent/precipitate Tc-separated product is currently undefined but we are recommending that the sodalite and metal alloy processes discussed in Section 7 of this review will be compatible Tc-specific waste forms. Fine-grained sodalite would require further processing to become either monolithic waste forms or encased in high integrity containers before the final disposal option is selected.

One option that has been previously evaluated is disposal of the off-gas LAW recycle stream directly to the ETF. However, this option has a number of problematical consequences to ETF itself, including increases in waste volume and problematically high levels of halides and radionuclides [see Lueck and Mcnamar (2008) and May et al. (2009) for details]. Some of these consequences would be mitigated by concentration and Tc decontamination of the off-gas recycle waste stream. The first proposed approach is to concentrate the off-gas waste stream using either traditional evaporation or reverse osmosis. The bottoms from the evaporator or concentrated brine from the reverse osmosis unit would be returned to DSTs or WTP, (when operational) for recycle through the LAW melters. The condensate from the evaporator or the permeate from the reverse osmosis unit would be sent to LERF and then on to ETF for final processing. In the second alternative treatment process (McCabe et al. 2013), separation of the radionuclides would be done by precipitation or sorption using inorganic reagents followed by settling and/or filtration of the sorbents. This proposed alternative treatment process is assumed to occur at the ETF after the recycled off-gas secondary waste stream is first segregated in one of the three lined and covered LERF basins; although such segregation of particular waste streams in not currently practiced.

Robbins and May (2013) also evaluate similar options for diverting the off-gas secondary liquid waste stream from recycling back to the LAW melters. Their study only looks at SBS/WESP condensate from the LAW facility and does not include the HLW SBS/WESP. In their analysis they assumed that the Tc depleted stream could be processed at a modified Effluent Treatment Facility (ETF). For each alternative, the approach would be to pump the liquid from the LAW Facility condensate collection tanks to a new Technetium Removal Facility (TRF) located outside of the WTP facility boundary but within the Hanford Site. It is presumed that it may be possible to combine the TRF processing facility into other proposed WTP facilities. The modifications to the LAW Facility are the same for all their alternatives.

\subsection{Recommended Tc-Specific Waste Forms}

In this final sub-section we re-visit the available data on the three most promising Tc-specific waste forms and offer some details on how we would advance the state of knowledge for these promising waste forms. 


\subsubsection{Metal Alloy Waste Form}

Based on the survey conducted in this report it appears that a metal alloy is the Tc-specific waste form most compatible with the Tc-separated waste streams. It is a particularly attractive option, offering several benefits for the stabilization and long-term storage of Tc. The advantages of the metal alloy waste form (especially a stainless steel (316SS)-based metal alloy) include the following:

1. An extremely small immobilized waste volume would result in a small footprint for final disposal. The total 316SS metal waste form required to immobilize the entire Tc inventory in the Hanford tanks of 26,500 $\mathrm{Ci}(1530 \mathrm{~kg})$ is estimated to be
a. waste loading of 5 mass $\%=30,588 \mathrm{~kg}\left(3.82 \mathrm{~m}^{3}\right)$ waste form
b. waste loading of 10 mass $\%=15,294 \mathrm{~kg}\left(1.91 \mathrm{~m}^{3}\right)$ waste form
c. waste loading of 20 mass $\%=7,647 \mathrm{~kg}\left(0.96 \mathrm{~m}^{3}\right)$ waste form

2. A relatively easy fabrication process impervious to upsets

3. The use of an economical and readily available material (316SS)

4. A resistance to corrosion, which can be greatly increased by surface passivation and placing the metal alloy waste form inside an outer container

5. The stabilization of Tc as metal $\left(\mathrm{Tc}^{0}\right)$. Oxidation of the Tc surface in the metal alloy was studied (Taylor 2014). Oxygen chemisorption to $\mathrm{Tc}^{0}$ is very strong, implying that formation of a full surface monolayer of chemisorbed oxygen is preferred to the nucleation of oxide islands. The films are strongly adherent, thus providing a stabile passive surface on the Tc metal.

6. A metal waste form is compatible with Tc streams generated by the separation of either LAW or off-gas condensate streams.

The metal waste form requires the Tc stream to be free of alkali metal species but can accommodate other transition metals, such as $\mathrm{Cr}, \mathrm{Ni}, \mathrm{Fe}, \mathrm{Al}, \mathrm{Sn}$, and Si. Therefore neither the SuperLig 639 eluate nor off-gas condensate are directly suited for the fabrication of the metal waste form without further purification. Currently, the most attractive route to purify and pre-concentrate Tc from these waste streams is by $\mathrm{Tc}(\mathrm{VII})$ reduction to $\mathrm{Tc}(\mathrm{IV})$ using $\mathrm{Sn}(\mathrm{II})$ materials. The co-reduction of $\mathrm{Cr}(\mathrm{VI})$ to $\mathrm{Cr}(\mathrm{III})$ followed by its co-precipitation with Tc(IV) and the presence of residual Sn will not interfere with the fabrication of the metal alloy waste form. Separated solid Tc(IV) will be reduced to $\mathrm{Tc}(0)$ metal by steam reforming in wet argon. It can be then combined with 316SS additives and melted into an alloy to produce the consolidated waste form.

Reductive $\mathrm{Fe}^{0}$ column separation of Tc from the SuperLig 639 eluate or off-gas condensate followed by fabrication of the 316SS metal alloy waste form using Tc-loaded iron/iron oxide column material is also a very economical and attractive option. However, the reductive $\mathrm{Fe}^{0}$ column separation method to remove Tc from liquid waste streams has undergone little testing and requires further development and demonstration.

Another (even though less attractive than reductive separation using Sn(II) materials) option to purify and pre-concentrate Tc from the SuperLig 639 eluate or off-gas condensate is to use ion exchange. Among ion exchange technologies available to date for the separation of Tc (see Section 6), Reillex HPQ offers advantages of high loading capacity, being elutable, and provides a stream concentrated in $\mathrm{TcO}_{4}{ }_{4}$. 
To generate Tc eluate compatible with metal alloy waste forms, the Tc-loaded Reillex HPQ can be eluted with $1 \mathrm{M} \mathrm{NH}_{4} \mathrm{OH}$. Separated Tc would then be reduced to Tc(0) metal by steam reforming in wet argon, combined with 316SS additives, and melted into an alloy to produce the consolidated waste form.

\subsubsection{Glass-Bonded Sodalite Waste Form}

Even though a sodalite waste form is in early stages of development, it is considered as potentially promising due to its ability to sequester Tc in its oxidized anionic $\mathrm{TcO}_{4}{ }^{-}$form, which the most mobile Tc form in the environment. Another advantage is economical and readily available sodalite precursors including sodium aluminate and colloidal silica. The downside is that this technology is in early stages of development. As mentioned above, very little work has been done to incorporate $\mathrm{TcO}_{4}{ }^{-}$into sodalite and what has been done was at a very small scale. Sodalite on the other hand can accommodate significant amounts of alkali cations such as sodium and anions such as nitrate and carbonate. However, formation of the $\mathrm{TcO}_{4}{ }^{-}$sodalite in the presence of the other ions present from the eluates should be experimentally evaluated.

We propose that a $\mathrm{ReO}_{4}{ }^{-}$-laden sodalite first be made with simulated Tc separated liquid waste streams to demonstrate proof of concept. The yield and process efficiency should be determined as the amount of sodalite made compared to what was expected and the efficiency determined based on how much $\mathrm{NaReO}_{4}$ was reacted versus how much remains in the residual solution. This work could be done in a non-rad facility so that the most effective experimental parameters for maximizing sodalite yield can be determined. Then, at least one test should be conducted where $\mathrm{NaReO}_{4}$ is replaced with $\mathrm{NaTcO}_{4}$. The products from all tests should be characterized with SEM-EDS and XRD. If time and funding permit, chemical durability tests (leach tests of the resultant sodalite) should be conducted to further evaluate the performance of the Tc-laden product.

The presence of significant concentrations of competing ions in the SuperLig 639 eluate or off-gas condensate can potentially hinder incorporation of $\mathrm{TcO}_{4}{ }^{-}$into the sodalite structure. Compatibility of potential eluates with formation of the $\mathrm{TcO}_{4}{ }^{-}$sodalite should be examined. For example, if $\mathrm{Tc}(\mathrm{VII})$ is separated from the SuperLig 639 eluate or off-gas condensate waste streams by reduction using Sn(II)based materials, the precipitated Tc(IV) should be re-oxidized back to Tc(VII) and solubilized in the aqueous $\mathrm{NaOH}$ solution. If $\mathrm{TcO}_{4}{ }^{-}$is separated by ion exchange, i.e., Reillex HPQ, it should be eluted from the loaded resin by $1 \mathrm{M} \mathrm{NaOH} / 1 \mathrm{M}$ ethylenediamine/0.005 $\mathrm{M} \mathrm{SnCl}_{2}$ solution or by a $1 \mathrm{M} \mathrm{NH}_{4} \mathrm{OH}$ solution.

Once the $\mathrm{TcO}_{4}{ }^{-}$sodalite is obtained, it should be combined with glass binders. The purpose of adding a glass binder to sodalite (and for most of the mineral forms) is that it helps reduce the surface area during consolidation, thus improving the chemical durability of the final Tc-laden waste form. This approach has been used successfully to bind sodalite for the baseline ceramic waste form used to immobilize spent electrochemical salt wastes (Bateman et al. 2007; Lepry et al. 2013; Riley et al. 2012). In these studies, the addition of the glass binder was used to decrease the porosity of the final product and to immobilize the fission products from the salt waste that could not be incorporated into the mineral structure of the sodalite, e.g., lanthanide and alkaline earth chlorides. However, in the $\mathrm{TcO}_{4}{ }^{-}$sodalite case, the binder would be used solely to bind the sodalite particles together. Also, the amount of glass binder required could likely be kept at no more 10-20 mass\% to optimize the overall Tc loading in the final waste form, although this has yet to be verified with $\mathrm{TcO}_{4}{ }^{-}$sodalite. The glass binders used for aiding in the consolidation of sodalite are typically high silica ( $\geq 60$ mass\%) borosilicate compositions with large working temperature ranges such as P57 and NBS-1 or derivatives thereof (O’Holleran 1999; Riley et al. 
2012; Ebert and Snyder 2015) although a lower-melting glass with a lower silica fraction might be required for working with Tc-sodalite to prevent Tc volatilization during consolidation.

\subsubsection{Goethite Waste Form}

Goethite is a relatively mature Tc-specific waste (Westsik et al. 2014 and references therein). Removal of Tc from a LAW melter off-gas recycle simulated using goethite reductive precipitation has been previously demonstrated (see Um et al. 2010, 2011, 2015). This process is also potentially possible for the SuperLig 639 eluate. However goethite requires a final Tc waste stream that contains little or no phosphate and sulfate anions. Experimental and theoretical studies showed that Tc(VII) should be reduced to form $\mathrm{Tc}(\mathrm{IV})$ that gets incorporated into octahedral sites in the Fe mineral goethite or in a spinel. Therefore the presence of chromate should be considered since Fe(II) will reduce both $\mathrm{Cr}(\mathrm{VI})$ and $\mathrm{Tc}(\mathrm{VII})$ in the waste stream, and thus increased quantities of Fe(II) reductant are needed. The reduced $\mathrm{Cr}$ (III) can also potentially compete with Tc(IV) for the structural sites in the goethite or spinel. One drawback of goethite is the low loading for Tc achieved to date (see Section 7) so that a large volume of the goethite waste form would be need to stabilize significant quantities of Tc. Never the less, the goethite waste form should be considered since it potentially can separate and immobilize Tc from the SuperLig 639 eluate and off-gas condensate directly without further purification. However, more testing is required to demonstrate this.

If Tc can be incorporated into the goethite structure using the SuperLig 639 eluate directly, its $\mathrm{pH}$ should be adjusted to $<4$ and then $\mathrm{Fe}(\mathrm{OH})_{2}$ and goethite added (for seeding further precipitation of ferric oxide). Solution $\mathrm{pH}$ is changed back to alkaline ( $\mathrm{pH} \sim 12$ is optimal), and the slurry is heated up to $80^{\circ} \mathrm{C}$ for several days. Solids are separated from the slurry, and Tc-laden ferric oxide fine particles are combined into a binder such as grout. Alternatively Tc-laden ferric oxide might be used as glass former solids for LAW vitrification or hot pressed or sintered into a monolithic waste form. The off-gas condensates can also be directly used to create Tc-laden ferric oxides using similar process. One potential disadvantage of the goethite waste form is studies to date have shown low Tc loading in the final goethite product. Additional studies using Tc separated liquid waste stream simulants are recommended to attempt to increase Tc loading into the final goethite product. 


\subsection{References}

Abraham DP, JW Richardson Jr, and SM McDeavitt. 1997. "Laves intermetallics in stainless steelzirconium alloys." Materials Science and Engineering: A 239-240:658-64.

Adamson DJ, CA Nash, DJ McCabe, CL Crawford. 2013. Laboratory Testing of Hanford Waste Treatment Plant Low Activity Waste Recycle Simulant. SRNL-STI-2013-0071, Savannah River National Laboratory, Aiken, SC.

Afanasiev P and C Geantet. 1998. "Synthesis of solid materials in molten nitrates." Coordination Chemistry Reviews 178(2):1725-52.

Alliot Llorens I, P Deniard, E Gautron, A Olicard, M Fattahi, S Jobic, and B Grambow. 2008. "Structural investigation of coprecipitation of technetium-99 with iron phases." Radiochimica Acta 96(9-11):569-74.

Arm ST, RD Claghorn, LH Cree, JM Colby, MS Fountain, DW Nelson, VC Nguyen, RM Russell, and ME Stone. 2015. One System River Protection Project Integrated Flowsheet. RPP-RPT-57991, Rev. 1, One System, Richland, WA.

Arm ST, JM Colby, M Fountain, V Nguyen, R Russell, L Sasaki, and M Stone. 2014. One System: Tank Waste Disposition Integrated Flowsheet - River Protection Project Reference Integrated Flowsheet. RPP-RPT-57991, Rev. 0, Washington River Protection Solutions, LLC, Richland, WA.

Ashley KR, GD Whitener, NC Schroeder, JR Ball and SD Radzinski. 1999. "Reillex ${ }^{\mathrm{TM}}$-HPQ Anion Exchange Column Chromatography: Removal of Pertechnetate from DSSF-5 Simulant at Various Flow Rates.” Solvent Extraction and Ion Exchange. 17(6):1543-1556.

Ashley KR, R Turner, JR Ball, KD Abney and NC Schroeder. 1995. “,Breakthrough Volumes of $\mathrm{TcO}_{4}{ }^{-}$ on Reillex ${ }^{\mathrm{TM}}$-HPQ Anion Exchange Resin in a Hanford Double Shell Tank Simulant.” $J$. Radioanalytical Nuc. Chern. Articles. 121:71-79.

Asmussen RA, CI Pearce, AR Lawter, RE Clayton, J Stephenson . B Miller, M Bowden, E Buck, N Washton, BD Williams, JJ Neeway and N Qafoku. 2016. Getter Incorporation into Cast Stone and Solid State Characterizations. PNNL-in press, Pacific Northwest National Laboratory, Richland, WA.

Baek JG, T Isobe, and M Senna. 1997. "Synthesis of Pyrochlore-Free 0.9Pb( $\left.\mathrm{Mg}_{1 / 3} \mathrm{Nb}_{2 / 3}\right) \mathrm{O}_{3}-0.1 \mathrm{PbTiO}_{3}$ Ceramics via a Soft Mechanochemical Route." Journal of the American Ceramic Society 80(4):973-81.

Bateman KJ, CJ Knight, and CW Solbrig. 2007. Current Status of Ceramic Waste Form Development. INL/INT-06-11736, Rev. 1, Idaho National Laboratory, Idaho Falls, ID.

Belsher JD, PA Empey, TM Hohl, RA Kirkbride, JS Ritari, EB West, LM Bergmann, and MN Wells. 2012. Hanford Tank Waste Operations Simulator (HTWOS) Version 7.4 Model Design Document. RPP-17152, Rev. 7, Washington River Protection Solutions, Richland, WA.

Blanchard Jr. DL, GN Brown, SD Conradson, SK Fadeff, GR Golcar, NJ Hess, GS Klinger, and DE Kurath. 1997. Technetium in Alkaline, High-Salt Radioactive Tank Waste Supernate: Preliminary Characterization and Removal. PNNL-11386, UC-2030, Pacific Northwest National Laboratory, Richland, WA. 
Blanchard Jr. DL, DE Kurath, GR Golcar, and SD Conradson. 1996. Technetium Removal Column Flow Testing with Alkaline, High Salt, Radioactive Tank Waste. PNNL-11398, Pacific Northwest National Laboratory, Richland, WA.

Brown CF, JH Westsik Jr, RJ Serne, BM Rapko, WR Wilmarth, DJ McCabe, CA Nash, AD Cozzi, KM Fox. 2014. Preliminary Assessment of the Low-Temperature Waste Form Technology Coupled with Technetium Removal. PNNL-22103, SRNL-STI-2013-00002, Pacific Northwest National Laboratory. P.O. Box 999, Richland, WA 99352.

Brown GM., B Gu, BA Moyer, and PV Bonneson. 2002. Regeneration of Anion Exchange Resins by Sequential Chemical Displacement. US patent US6448299 B1.

Burgeson IE, JR Deschane, and DL Blanchard. 2005. "Removal of Technetium from Hanford Tank Waste Supernates.” Separation Science and Technology 40(1-3):201-223.

Burgeson IE, DL Blanchard Jr, and JR Deschane. 2004a. Small Column Testing of Superlig 639 for Removing 99Tc from Hanford Tank Waste 241-AN-102 Supernate (Envelope C) Mixed with Tank 241-C-104 Solids (Envelope D) Wash and Permeate Solutions. PNWD-3252, Rev. 1, Battelle-Pacific Northwest Division, Richland, WA.

Burgeson IE, DL Blanchard Jr., and JR Deschane. 2004b. Small Column Testing of Superlig 639 for Removing 99Tc from Hanford Tank Waste Envelope B (Tank 241-AZ-101). PNWD-3281, Battelle-Pacific Northwest Division, Richland, WA.

Chatterjee S, TG Levitskaia, J Romero, J Peterson, N Pence, T Varga, M Bowden, M Engelhard, B Arey, L Kovarik. 2015. Novel Inorganic Composites for Technetium Management. Presented at Radionuclide Migration 2015 Conference, Santa Fe NM, September 2015.

Chen D, X Jiao, Y Zhao, and M He. 2003. "Hydrothermal synthesis and characterization of octahedral nickel ferrite particles.” Powder Technology 133(1):247-250.

Chen J, C Sorensen, K Klabunde, G Hadjipanayis, E Devlin, and A Kostikas. 1996. "Size-dependent magnetic properties of $\mathrm{MnFe}_{2} \mathrm{O}_{4}$ fine particles synthesized by coprecipitation.” Physical Review $B$ 54(13):9288-9296.

Crum JV, D Strachan, A Rohatgi, and M Zumhoff. 2013. "Epsilon metal waste form for immobilization of noble metals from used nuclear fuel.” Journal of Nuclear Materials 441(1-3):103-112.

Darab JG and PA Smith. 1996. "Chemistry of technetium and rhenium species during low-level radioactive waste vitrification.” Chemistry of Materials 8(5):1004-1021.

Del Cul G and W Bostick. 1995. "Simple method for technetium removal from aqueous solutions.” Nuclear Technology 109(1):161-162.

den Exter MJ, S Neumann, and T Tomasberger. 2006. Immobilization and Behavior of Technetium in a Magnesium Titanate Matrix for Final Disposal. In Proceedings of Sci. Basis Nucl. Waste Manag. XXIX eds. P Van Iseghem, 567-74 pp, Materials Research Society.

Deutsch WJ, KJ Cantrell, KM Krupka, ML Lindberg, and RJ Serne. 2011. "Hanford tank residual waste - Contaminant source terms and release models.” Applied Geochemistry 26(9-10):1681-1693. 
Dickson JO, JB Harsh, M Flury, WW Lukens, and EM Pierce. 2014. “Competitive Incorporation of Perrhenate and Nitrate into Sodalite.” Environmental Science \& Technology 48(21):12851-1257.

Duncan JB, K Hagerty, WP Moore, RN Rhodes, JM Johnson, and RC Moore. 2012. Laboratory Report on the Reduction and Stabilization (Immobilization) of Pertechnetate to Technetium Dioxide Using Tin(II)apatite. LAB-RPT-12-00001, Washington River Protection Solutions LLC, Richland, WA.

Duncan J, S Kelly, R Robbins, R Adams, M Thorson, and C Haass. 2011. Technetium Sorption Media Review. RPP-RPT-50122, Washington River Protection Solutions, Richland, WA.

Ebert WL and CT Snyder. 2015. Corrosion Tests with Waste Forms Developed for Echem Salt Wastes. FCRD-MRWFD-2015-000145, Argonne National Laboratory, Lemont, IL.

Ebert W, J Cunnane, M Williamson, S Frank, EC Buck, D Kolman, E Mausolf, and D Shoesmith. 2010. FY2010 Status Report: Developing an Iron-Based Alloy Waste Form. AFCI-WAST- 2010-000161, Argonne National Laboratory, Lemont, IL.

Ebert W, M Williamson, and S Frank. 2009. Immobilizing Tc-Bearing Waste Streams in an Iron-Based Alloy Waste Form. AFCI-WAST-PMO-MI-DV-2009-000160, Lemont, IL, Argonne National Laboratory.

Geselbracht MJ, LD Noailles, LT Ngo, JH Pikul, RI Walton, ES Cowell, F Millange, and D O'Hare. 2004. "Probing molten salt flux reactions using time-resolved in situ high-temperature powder X-ray diffraction: a new synthesis route to the mixed-valence $\mathrm{NaTi}_{2} \mathrm{O}_{4}$." Chemistry of Materials 16(6):11531159.

Giannakopoulou T, L Kompotiatis, A Kontogeorgakos, and G Kordas. 2002. "Microwave behavior of ferrites prepared via sol-gel method.” Journal of Magnetism and Magnetic Materials 246(3):360-365.

Gu B, GM Brown, L Maya, MJ Lance, and BA Moyer. 2001. "Regeneration of perchlorate $\left(\mathrm{ClO}_{4}{ }^{-}\right)^{-}$ loaded anion exchange resins by a novel tetrachloroferrate $\left(\mathrm{FeCl}_{4}^{-}\right)$displacement technique.” Environmental Science Technology 35:3363-3368.

Hamm LL, FG Smith, III, SE Aleman, and DJ McCabe. 2013. Upgrade to Ion Exchange Modeling for Removal of Technetium from Hanford Waste Using SuperLig®639 Resin. SRNL-STI-2013-00160, Rev 0, Savannah River National Laboratory, Aiken, SC.

Hartmann T, AJ Alaniz, and DJ Antonio. 2012. "Fabrication and properties of technetium-bearing pyrochlores and perovskites as potential waste forms.” Procedia Chemistry 7:622-28.

Hartmann T, A Alaniz, F Poineau, P Weck, J Valdez, M Tang, G Jarvinen, K Czerwinski, and K Sickafus. 2011. "Structure studies on lanthanide technetium pyrochlores as prospective host phases to immobilize ${ }^{99}$ technetium and fission lanthanides from effluents of reprocessed used nuclear fuels.” Journal of Nuclear Materials 411(1):60-71.

Huang K, M Feng, and JB Goodenough. 1996. "Sol-gel synthesis of a new oxide-ion conductor Sr- and Mg-doped $\mathrm{LaGaO}_{3}$ perovskite.” Journal of the American Ceramic Society 79(4):1100-04.

Janzten CM, EM Pierce, CJ Bannochie, PR Burket, AD Cozzi, CL Crawford, WE Daniel, KM Fox, CC Herman, DH Miller, DM Missimer, CA Nash, MF Williams, CF Brown, NP Qafoku, JJ Neeway, MM Valenta, GA Gill, DJ Swanberg, RA Robbins, and LE Thompson. 2014. Fluidized Bed Steam 
Reformed Mineral Waste Form Performance Testing to Support Hanford Supplemental Low Activity Waste Immobilization Technology Selection. SRNL-STI-2011-00387, Savannah River National Laboratory, Aiken, SC.

Jantzen CM, CL Crawford, CJ Bannochie, PR Burket, AD Cozzi, WE Daniel, HK Hall, DH Miller, DM Missimer, CA Nash, and MF Williams. 2013. Radioactive demonstration of mineralized waste forms made from Hanford Low Activity Waste (Tank Farm Blend) by Fluidized Bed Steam Reformation (FBSR). SRNL-STI-2011-00383, Savannah River National Laboratory, Aiken, SC.

Kang M, S Rhee, H Moon, V Neck, and T Fanghanel. 1996. "Sorption of $\mathrm{MO}_{4}{ }^{-}(\mathrm{M}=\mathrm{Tc}, \mathrm{Re})$ on $\mathrm{Mg} / \mathrm{Al}$ layered double hydroxide by anion exchange.” Radiochimica Acta 75(3):169-73.

Keiser Jr. DD, DP Abraham, and JW Richardson Jr. 2000. "Influence of technetium on the microstructure of a stainless steel-zirconium alloy.” Journal of Nuclear Materials 277(2-3):333-38.

Kim D-S, LM Bagaasen, JV Crum, A Fluegel, AF Gallegos, B Martinez, J Matyas, PA Meyer, D Paulsen, and BJ Riley. 2006. Investigation of Tc migration mechanism during bulk vitrification process using Re surrogate. PNNL-16267, Pacific Northwest National Laboratory, Richland, WA.

Kimura T. 2011. "Molten Salt Synthesis of Ceramic Powders.” In Advances in Ceramics - Synthesis and Characterization, Processing and Specific Applications, ed. C Sikalidis, InTech.

King WD and TB Calloway. 2000. Tank 241-AZ-102 SuperLig 639 Technetium Ion Exchange Eluate Evaporation Study. WSRC-TR-2000-00424, SRT-RPP-2000-00024, Rev. 0, Westinghouse Savannah River Company, Savannah River Site, Aiken, SC.

Kurath DE and JJ Wagner. 2000. Analysis of Spent Ion Exchange Media: Superlig 639 and Superlig 644. PNWD-3037, BNFL-RPT-028 Rev. 0, Battelle--Pacific Northwest Division, Richland, WA.

Laurent S, D Forge, M Port, A Roch, C Robic, L Vander Elst, and RN Muller. 2008. "Magnetic iron oxide nanoparticles: synthesis, stabilization, vectorization, physicochemical characterizations, and biological applications." Chemical Reviews 108(6):2064-110.

Lepry WC, BJ Riley, JV Crum, CP Rodriguez, and DA Pierce. 2013. "Solution-based approaches for making high-density sodalite waste forms to immobilize spent electrochemical salts.” Journal of Nuclear Materials 442(1-3):350-359.

Lueck KJ and EA Mcnamar. 2008. Low Activity Waste (LAW) Facility Secondary Waste to Effluent Treatment Facility (ETF) Treatability Evaluation. HNF-37718, Rev 0, Fluor Hanford Company, Richland, WA.

Lukens WW, N Magnani, T Tyliszczak, and DK Shuh. 2012. Technetium incorporation into ferrite spinels. Presented at American Chemical Society, DOE BES CSGB Review.

Luksic S, BJ Riley, M Schweiger, and P Hrma. 2015. "Incorporating Technetium in Minerals and Other Forms: A Review.” Journal of Nuclear Material 466:526-538.

Matlack KS, H Abramowitz, M Brandys, IS Muller, RA Callow, N D’Angelo, R Cecil, I Joseph, and IL Pegg.2012. Technetium Retention in WTP LAW Glass with Recycle Flow-Sheet: DM10 Melter Testing. VSL-12R2640-1,Vitreous State Laboratory, The Catholic University of America Washington, DC 
Matlack KS, W Gong, G Diener, T Bardakci, M Brandys, and IL Pegg. 2006. Final Report; Summary of DM1200 SBS History and Performance. VSL-066410-2, The Catholic University of America, Vitreous State Laboratory, Washington, D.C.

Mattigod SV, BP McGrail, DE McCready, L-Q Wang, KE Parker, and JS Young. 2006. “Synthesis and structure of perrhenate sodalite.” Microporous and Mesoporous Materials 91(1-3):139-44.

May TH, PD Gehner, G Stegen, J Hymas, A Pajunen, R Sexton, and A Ramsey. 2009. Secondary Waste - ETF Pre-Conceptual Engineering Study. RPP-RPT-43588, Rev 0, Washington River Protection Solutions, LLC, Richland, WA.

McCabe DJ, MR Poirier, and DT Hobbs. 2012. Technetium Removal Technology Down-Selection Data Package. SRNL-STI-2012-00476, Savannah River National Laboratory, Aiken, SC.

McCabe DJ, WR Wilmarth, and CA Nash. 2013. Waste Treatment Technology Process Development Plan for Hanford Waste Treatment Plant Low Activity Waste Recycle. SRNL-STI-2013-00351, Rev. 0, Savannah River National Laboratory, Aiken, SC.

McDeavitt SM, DP Abraham, and JY Park. 1998. "Evaluation of stainless steel-zirconium alloys as high-level nuclear waste forms.” Journal of Nuclear Materials 257(1):21-34.

Missimer D and R Rutherford. 2013. Preparation and Initial Characterization of Fluidized Bed Steam Reforming Pure-Phase Standards. SRNL-STI-2013-00111, Savannah River National Laboratory, Aiken, SC.

Muller O, WB White, and R Roy. 1964. "Crystal chemistry of some technetium-containing oxides.” Journal of Inorganic and Nuclear Chemistry 26(12):2075-86.

Nash CA, KML Taylor-Pashow, and DJ McCabe. 2014. Laboratory Preparation of Hanford Waste Treatment Plant Direct Feed Low Activity Waste Off-Gas Condensate Simulant. SRNL-STI-2014-00602, Savannah River National Laboratory, Aiken, SC.

Nash CA, MR Duignan, and CE Duffey. 2006. Batch, Kinetic, and Column Data from ResorcinolFormaldehyde Resin for Cs-137 Removal from Pre-Treated Hanford Tank 241-AP-101 Diluted Feed (Envelope A). WSRC-STI-2006-00071, Westinghouse Savannah River Company, Savannah River National Laboratory, Aiken, SC.

Neeway JJ, NP Qafoku, BD Williams, KA Rod, ME Bowden, CF Brown, and EM Pierce. 2014. "Performance of the fluidized bed steam reforming product under hydraulically unsaturated conditions." Journal of Environmental Radioactivity 131:119-128.

O’Holleran TP. 1999. Ceramic Waste Form Intergranular Glass Composition. NT-NWM-(TO)-99-010, Argonne National Laboratory, Lemont, IL.

Pegg IL. 2015. "Behavior of technetium in nuclear waste vitrification processes.” Journal of Radioanalytical Nuclear Chemistry 305:287-292.

Pierce EM, WW Lukens, JP Fitts, CM Jantzen, and G Tang. 2014. "Experimental determination of the speciation, partitioning and release of perrhenate as a chemical surrogate for pertechnetate from a sodalite-bearing multiphase ceramic waste form.” Applied Geochemistry 42:47-59. 
Poineau F, J Du Mazaubrun, D Ford, J Fortner, J Kropf, GWC Silva, N Smith, K Long, G Jarvinen and K Czerwinski. 2008. "Uranium/technetium separation for the UREX process - synthesis and characterization of solid reprocessing forms.” Radiochim. Acta 96: 527-533.

Purolite A532E. 2015. Accessed on July 13, 2015, 2015 at

http://www.purolite.com/Customized/CustomizedControls/PuroliteProductsManagement/PopupPage.aspx ?RelID=619436\&Action=ProductDataSheetPDF\&LanguageID=\&registered=1.

Qafoku NP, JJ Neeway, AR Lawter, TG Levitskaia, RJ Serne, JJ Westsik, and MMV Snyder. 2014. Technetium and Iodine Getters to Improve Cast Stone Performance. PNNL-23282, Pacific Northwest National Laboratory, Richland, WA.

Rapko BM, SA Bryan, JL Bryant, S Chatterjee, MK Edwards, JY Houchin, T Janik, TG Levitskaia, JM Peterson, RA Peterson, SI Sinkov, FN Smith, and R Wittman. 2013a. Development of a Chemistry-Based, Predictive Method for Determining the Amount of Non-Pertechnetate Technetium in the Hanford Tanks: FY2012 Progress Report. PNNL-22173, Pacific Northwest National Laboratory, Richland, WA.

Rapko BM, SA Bryan, S Chatterjee, MK Edwards, TG Levitskaia, JM Peterson, RA Peterson, and SI Sinkov. 2013b. Investigations into the Nature of Alkaline Soluble, Nor-Pertechnetate Technetium. PNNL-22957, Pacific Northwest National Laboratory, Richland, WA.

Rapko, BM, DL Blanchard, and KJ Carson. 2003. Equilibrium Batch Contact Testing of SuperLig®639. PNWD-3251, WTP-RPT-026, Rev 0, Battelle, Pacific Northwest Division, Richland, WA.

Reillex HPQ. 2015. Accessed on July 13, 2015, at http://www.vertellus.com/products/industrialspecialties/reillex-resins/reillex-hpq-polymer.

Riley BJ, JV Crum, J Matyáš, JS McCloy, and WC Lepry. 2012. "Solution-derived, chloride-containing minerals as a waste form for alkali chlorides." Journal of the American Ceramic Society 95(10):31153123.

Robbins RA and TH May. 2013. Submerged Bed Scrubber Condensate Technetium Removal and Disposal Preconceptual Engineering Study. RPP-RPT-55213, Rev. 0, Washington River Protection Solutions, LLC, Richland, WA.

Rodriguez EE. 2009. "Solid State Chemistry of Technetium and Rhenium Oxides.” University of California, Santa Barbara, Ph.D. Thesis.

Sasaki S, CT Prewitt, JD Bass, and W Schulze. 1987. "Orthorhombic perovskite $\mathrm{CaTiO}_{3}$ and $\mathrm{CdTiO}_{3}$ : structure and space group.” Acta Crystallographica Section C: Crystal Structure Communications 43(9):1668-74.

Serne RJ, BM Rapko, and IL Pegg. 2014. Technetium Inventory, Distribution, and Speciation in Hanford Tanks. PNNL-23319, Rev. 1, EMSP-RPT-022, Rev. 1, Pacific Northwest National Laboratory, Richland, WA.

Sisk M, I Kilbride, and A Barker. 1995. "Production of manganese zinc ferrites via the hydrothermal decomposition of metal (III) acetates and citrates." Journal of Materials Science Letters 14(3):153-54.

SuperLig ${ }^{\circledR}$ 639. 2015. Accessed on July 13, 2015, at http://www.ibcmrt.com/products/superlig/. 
Taylor CD. 2014. “Oxidation of technetium metal as simulated by first principles.” Journal of Physical Chemistry C, 118:10017-10023.

Taylor-Pashow KM, CA Nash, and DJ McCabe. 2015. Laboratory Optimization Tests of Decontamination of Cs, Sr, and Actinides from Hanford Waste Treatment Plant Low Activity Waste Off-Gas Condensate Simulant. SRNL-STI-2014-00613, Rev. 0, Savannah River National Laboratory, Aiken, SC.

Taylor-Pashow KML, CA Nash, and DJ McCabe. 2014a. Laboratory Optimization Tests of Technetium Decontamination of Hanford Waste Treatment Plant Low Activity Waste Off-Gas Condensate Simulant. SRNL-STI-2014-00436, Savannah River National Laboratory, Aiken, SC.

Taylor-Pashow KM, CA Nash, CL Crawford, DJ McCabe, and WR Wilmarth. 2014b. Laboratory Scoping Tests of Decontamination of Hanford Waste Treatment Plant Low Activity Waste Off-Gas Condensate Simulant. SRNL-STI-2013-00719, Rev. 0, Savannah River National Laboratory, Aiken, SC.

Thien MG, TA Wooley and AA Ramsey. 2015. River Protection Project Technology Roadmap. RPP-PLAN-43988, Rev. 1, Washington River Protection Solutions, Richland, WA.

TTT. 2009. Report for treating Hanford LAW and WTP SW simulants: Pilot Plant Mineralizing Flowsheet. RT-21-002, Rev. 1, THOR Treatment Technologies, LLC, Denver, CO.

Um W and SA Luksic. 2015. "Development of Tc(IV)-Incorporated Fe Minerals to Enhance ${ }^{99} \mathrm{Tc}$ Retention in Glass Waste Form.” Proceedings of Waste Management 2015, Phoenix AZ, March 2015. http://www.xcdsystem.com/wmsym/2015/papers/15239.pdf

Um W, H-s Chang, JP Icenhower, WW Lukens, RJ Serne, NP Qafoku, JJ Westsik, EC Buck, and SC Smith. 2011. "Immobilization of 99-Technetium (VII) by Fe(II)-Goethite and Limited Reoxidation." Environmental Science \& Technology 45(11):4904-1913.

Um W, H-s Chang, JP Icenhower, N Qafoku, SC Smith, RJ Serne, EC Buck, RK Kukkadapu, ME Bowden, and JH Westsik. 2010. Immobilization and Limited Reoxidation of Technetium-99 by Fe (II)-Goethite. PNNL-19833, Pacific Northwest National Laboratory, Richland, WA.

Westsik JH, K Cantrell, R Serne, and N Qafoku. 2014. Technetium Immobilization Forms Literature Survey. PNNL-23329, EMSP-RPT-023, Pacific Northwest National Laboratory, Richland, WA. 
PNNL-25834

EMSP-RPT-029 Rev. 0

\section{Distribution*}

U.S. Department of Energy Office of Environmental Management

NP Machara

R Rimando

G McKinley

J Pabon

Savannah River National Laboratory

DJ McCabe

Office of River Protection (ORP)

B Harp

A Kruger
Pacific Northwest National Laboratory

JV Crum

TG Levitskaia

GJ Lumetta

RA Peterson

BM Rapko

BJ Riley

RJ Serne

JD Vienna

Information Release (PDF)

\footnotetext{
*All distribution will be made electronically.
} 


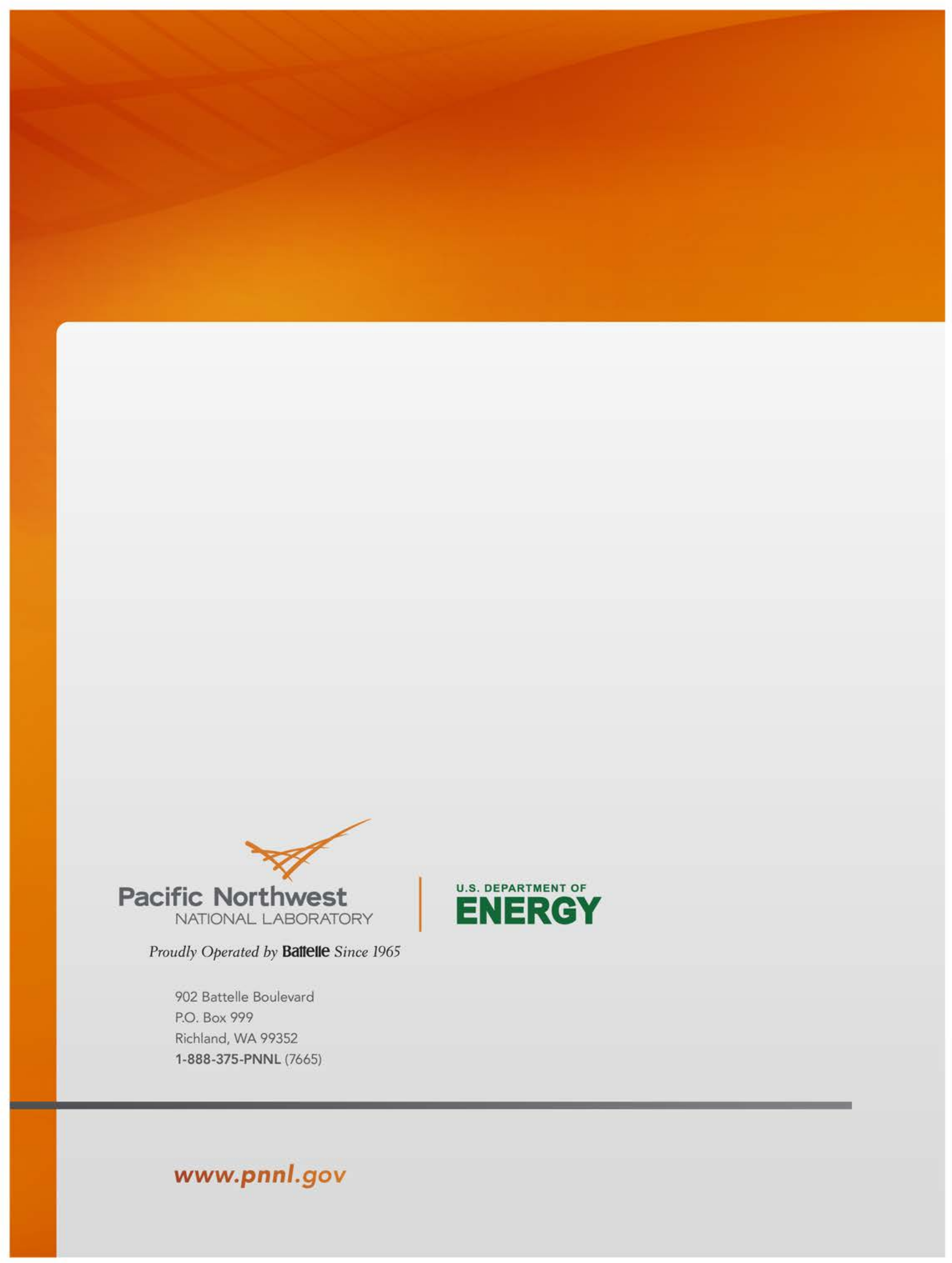

